\title{
Geochemical and Sulfur-Isotopic Signatures of Volcanogenic Massive Sulfide Deposits on Prince of Wales Island and Vicinity, Southeastern Alaska
}

\author{
By John F. Slack, Wayne C. Shanks III, Susan M. Karl, Pamela A. Gemery, \\ Peter E. Bittenbender, ${ }^{1}$ and W. Ian Ridley
}

\section{Abstract}

Stratabound volcanogenic massive sulfide (VMS) deposits on Prince of Wales Island and vicinity, southeastern Alaska, occur in two volcanosedimentary sequences of Late Proterozoic through Cambrian and of Ordovician through Early Silurian age. This study presents geochemical data on sulfide-rich samples, in situ laser-ablation inductively coupled plasma mass spectrometry (LA-ICP-MS) of sulfide minerals, and sulfur-isotopic analyses of sulfides and sulfates (barite) for identifying and distinguishing between primary sea-floor signatures and later regional metamorphic overprints. These datasets are also used here in an attempt to discriminate the VMS deposits in the older Wales Group from those in the younger Moira Sound unit (new informal name). The Wales Group and its contained VMS deposits have been multiply deformed and metamorphosed from greenschist to amphibolite grade, whereas the Moira Sound unit and related VMS deposits are less deformed and generally less metamorphosed (lower to middle greenschist grade). Variations in the sulfide mineral assemblages and textures of the VMS deposits in both sequences reflect a combination of processes, including primary sea-floor mineralization and sub-sea-floor zone refining, followed by metamorphic recrystallization. Very coarse grained $(>1 \mathrm{~cm}$ diam) sulfide minerals and abundant pyrrhotite are restricted to VMS deposits in a small area of the Wales Group, at Khayyam and Stumble-On, which record high-grade metamorphism of the sulfides.

Geochemical and sulfur-isotopic data distinguish the VMS deposits in the Wales Group from those in the Moira Sound unit. Although base- and precious-metal contents vary widely in sulfide-rich samples from both sequences, samples from the Moira Sound generally have proportionately higher $\mathrm{Ag}$ contents relative to base metals and Au. In situ LA-ICPMS analysis of trace elements in the sulfide minerals suggests that primary sea-floor hydrothermal signatures are preserved

${ }^{1}$ U.S. Bureau of Land Management. in some samples (for example, $\mathrm{Mn}, \mathrm{As}, \mathrm{Sb}$, and $\mathrm{Tl}$ in pyrite from the Moira Sound unit), whereas in other samples the signatures are varyingly annealed, owing to metamorphic overprinting. A limited LA-ICP-MS database for sphalerite indicates that low-Fe sphalerite is preferentially associated with the most Au rich deposits, the Niblack and Nutkwa.

Sulfur-isotopic values for sulfide minerals in the VMS deposits in the Wales Group range from 5.9 to 17.4 permil (avg $11.5 \pm 2.7$ permil), about 5 to 6 permil higher than those in the Moira Sound unit, which range from -2.8 to 10.4 permil (avg $6.1 \pm 4.0$ permil). This difference in $\delta^{34} \mathrm{~S}_{\text {sulfide }}$ values reflects a dominantly seawater sulfate source of the sulfides and is linked to the $\delta^{34} \mathrm{~S}$ values of contemporaneous seawater sulfate, which were slightly higher during the Late Proterozoic through Cambrian than during the Ordovician through Early Silurian.

\section{Introduction}

Stratabound volcanogenic massive sulfide (VMS) deposits occur worldwide in metasedimentary and metavolcanic rocks of Archean through Tertiary age (for example, Barrie and Hannington, 1999; Franklin and others, 2005). These commercially important mineral deposits form by submarine hydrothermal processes on and beneath the sea floor, depositing $\mathrm{Fe}, \mathrm{Cu}, \mathrm{Zn}$, and (or) $\mathrm{Pb}$ sulfide minerals that in places are accompanied by economic amounts of $\mathrm{Ag}, \mathrm{Au}, \mathrm{Sn}$, and other metals. In southeastern Alaska, VMS deposits are recognized in three major lithostratigraphic belts of Late Proterozoic through Cambrian, Ordovician through Silurian, and Triassic age that extend discontinuously from northwest of Haines in the north to Prince of Wales Island in the south (Newberry and others, 1997b). The Triassic deposits, which currently are the most important economically, include the polymetallic Greens Creek $\mathrm{Zn}-\mathrm{Pb}-\mathrm{Cu}-\mathrm{Ag}-\mathrm{Au}$ massive sulfide ore body that presently is being mined on Admiralty Island, $\sim 250 \mathrm{~km}$ northwest of Prince of Wales Island (Taylor, 1997; Newberry and Brew, 1999; Taylor and others, 1999). 
In this study, we report geochemical and sulfur-isotopic analyses of samples of massive and semimassive sulfides from the two older groups of VMS deposits and occurrences on southern Prince of Wales Island and vicinity (fig. 1). These data are used here together with geologic and textural features to better characterize the metallogeny of the deposits and to provide an analytical framework for potentially discriminating the Late Proterozoic through Cambrian from the Ordovician through Silurian VMS deposits in the region.

\section{Geologic and Metallogenic Setting}

Prince of Wales and surrounding islands (fig. 1) are underlain by a wide variety of stratified and intrusive rocks of Late Proterozoic through Tertiary age (Gehrels and Saleeby,
1987; Gehrels, 1990, 1992; see Karl and others, this volume) that constitute part of the regionally extensive Alexander terrane, which extends from eastern Alaska and southwestern Yukon Territory southward into southeastern Alaska and coastal British Columbia (for example, McClelland and others, 1992; Karl and others, 1999; Nokleberg and others, 2001). On Prince of Wales Island and vicinity, the oldest unit is the Upper Proterozoic through Cambrian Wales Group, which comprises various deformed metavolcanic and lesser metasedimentary rocks, including greenstone and amphibolite, felsic schist and gneiss, graphitic phyllite, minor marble, and sparse metaconglomerate (see Karl and others, this volume). The Wales Group also hosts most of the VMS deposits in the study area. The age of the Wales Group is constrained mainly by a concordant $\mathrm{U}-\mathrm{Pb}$ zircon age of $554 \pm 4 \mathrm{Ma}$ for a crosscutting granitic (now orthogneiss) pluton on southern Dall Island (fig. 1; Gehrels, 1990). A maximum age for the Wales Group

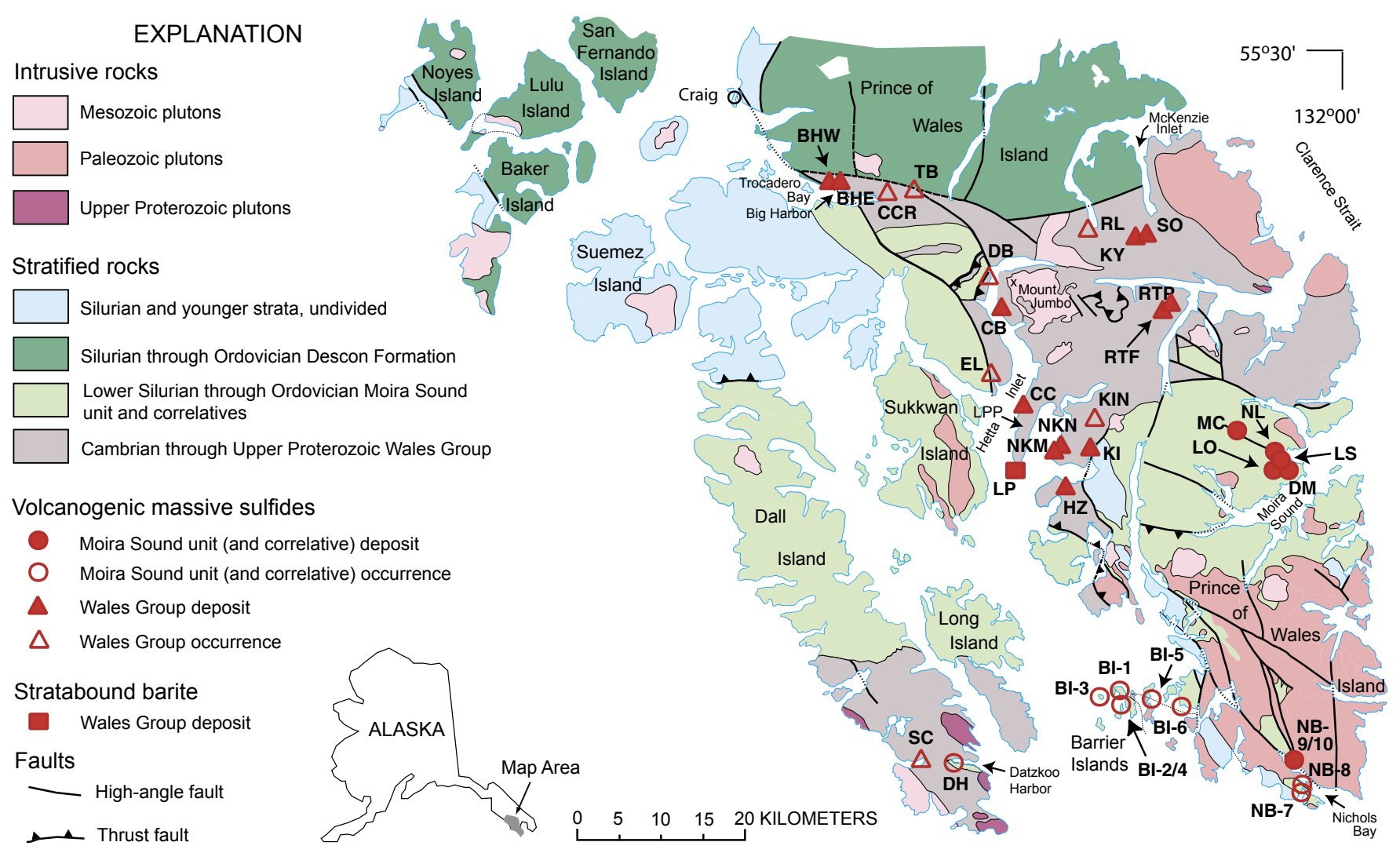

Figure 1. Simplified geologic map of southern Prince of Wales Island and vicinity, showing locations of volcanogenic massive sulfide deposits and occurrences in study area. Geology from Karl and others (this volume). Deposits and occurrences: BHE, Big Harbor East; BHW, Big Harbor West; BI, Barrier Islands; CB, Corbin; CC, Copper City; CCR, Cable Creek roadcut; DB, Deer Bay; DH, Datzkoo Harbor; DM, Dama; EL, Eek Lake; HZ, Hozer; KI, Keete Inlet; KIN, Keete Inlet North; KY, Khayyam; LO, Lookout Mountain; LP, Lime Point (barite); LS, Lindsy/88; MC, Moira Copper; NB, Nichols Bay; NKM, Nutkwa Main; NKN, Nutkwa North; NL, Niblack; RL, Rock Lake; RTF, Ruby Tuesday (Fish Show; includes the Chomly deposit); RTP, Ruby Tuesday (Polymetal); SC, Security Cove; SO, Stumble-On; TB, Trocadero Bay. In the Niblack area, the Trio and Broadgauge deposits (not shown) are located between the Dama and Lindsy/88 deposits. Numbered suffixes for Barrier Islands (BI-1 through BI-6) and Nichols Bay (NB-7 through NB-10) deposits and occurrences (table 1) correspond to those used by Gehrels and others (1983). Note that thick limestone and dolostone of the Moira Sound unit on Dall and Long Islands are not distinguished from other rock types in this sequence. 
is estimated at 600 m.y. on the basis of U-Pb geochronology of igneous zircons from apparently coeval plutons and of detrital zircons from younger strata (see Karl and others, this volume). Rocks of the Wales Group, together with several enclosed plutons, were deformed and regionally metamorphosed twice, in the Early Ordovician and Early Devonian. Geochemical studies of mafic metavolcanic rocks in the Wales Group reveal mainly transitional to midocean-ridge basalt (MORB) magmatic signatures that suggest formation in an oceanic-arc terrane (Barrie and Kyle, 1988; see Karl and others, this volume). Lead-isotopic values for sulfide minerals in the VMS deposits in the Wales Group are relatively unradiogenic, consistent with a primitive-arc setting for these deposits and their volcanosedimentary host sequence (see Ayuso and others, this volume).

Younger stratified metavolcanic and metasedimentary rocks of the Moira Sound unit (new informal name), which are dated at Early Ordovician through Silurian (see Karl and others, this volume), are economically important because, like the Wales Group, they also contain VMS deposits and occurrences. The Moira Sound unit consists dominantly of siltstone, mudstone, graywacke turbidite, and carbonaceous argillite, alternating with thick sections of mafic, intermediate-composition, and silicic volcanic rocks and minor conglomerate and limestone. Graptolites and conodonts range in age from late Early Ordovician to Early Silurian. The oldest dated pluton that intrudes the Moira Sound unit is a $472 \pm 5$-m.y.-old granodiorite on southern Prince of Wales Island (Gehrels and Saleeby, 1987), which probably was emplaced into the lower part of this sequence contemporaneously with deposition of the upper part of the Moira Sound unit; the youngest dated pluton that intrudes this unit, in Moira Sound, has a U-Pb zircon age of $427 \pm 4$ m.y. (R. Friedman, written commun., 2004). Geochemical data for the mafic volcanic rocks indicate mainly calc-alkaline petrologic affinities that imply deposition in an island-arc setting (see Karl and others, this volume).

Most younger strata in the study area (fig. 1) are dominated by sedimentary rocks. The widespread Descon Formation, of Middle Ordovician through Silurian age, comprises volcaniclastic graywacke turbidite, siliceous shale, chert, and minor calc-alkaline to alkaline basalt and andesite but no rhyolite or dacite. Various other Silurian and Devonian sedimentary rocks also occur in the region. None of these sequences contains massive sulfide deposits. Unconformably overlying the Paleozoic strata are Tertiary sedimentary rocks, including coal, Tertiary through Quaternary basalt, and various alluvial, colluvial, and glacial deposits.

Three major tectonometamorphic events affected Prince of Wales Island and vicinity. The first event was in the Late Proterozoic, as documented by 554-m.y.-old orthogneiss on Dall Island that cuts a preexisting fabric in rocks of the Wales Group (Gehrels, 1990). The second event was in the Early Ordovician, after deposition of the Wales Group but before deposition of the Moira Sound unit. This event produced isoclinal to recumbent folds and a regional metamorphic grade ranging from lower greenschist to upper amphibolite facies
(Gehrels and Saleeby, 1987; Gehrels, 1990). Peak conditions during this Ordovician metamorphism were temperatures of $610-690^{\circ} \mathrm{C}$ and pressures of 8.4 to $10.1 \mathrm{kbars}$ (Zumsteg and others, 2004). The third major event, which occurred in the Early Devonian as dated by Ar-Ar geochronology (see Karl and others, this volume), followed deposition of the Moira Sound unit and the Descon Formation, generating open folds, slaty cleavage, and greenschist-facies mineral assemblages. Peak metamorphic conditions during this event were a temperature of $\sim 535^{\circ} \mathrm{C}$ and a pressure of $6.8 \mathrm{kbars}$ (Zumsteg and others, 2004). Rocks of the Wales Group are generally recognizable by the presence of two periods of penetrative deformation (for example, F2 folds), in contrast to the single period of deformation that characterizes the Moira Sound unit (see Karl and others, this volume).

Plutonic rocks in the region are abundant and vary widely in age and petrology. Geologic and geochronologic data indicate ages of Late Proterozoic, Ordovician, Silurian, Devonian, Permian, Jurassic, and Cretaceous (Gehrels and Saleeby, 1987; see Karl and others, this volume) and compositions ranging from granite, through syenite, to gabbro and pyroxenite. Some of the Paleozoic and Mesozoic plutons are genetically related to economically important magmatic-hydrothermal ore deposits, including the Devonian Kasaan and the Cretaceous Jumbo-Copper Mountain Fe-Cu-Au skarns (Wright, 1915; Newberry and others, 1997a), the Devonian through Silurian Salt Chuck Cu-Au-Ag-Pd-Pt deposit (Watkinson and Melling, 1992; Foley and others, 1997), and the Jurassic Bokan Mountain U-Th-rare-earth-element-Nb-Ta dike system (Thompson, 1988; Foley and others, 1997). Small posttectonic base- and precious-metal veins are widespread in the region, some of which are spatially associated with the Paleozoic and Mesozoic plutons (Maas and others, 1995).

Faults are common throughout the study area (fig. 1; see Karl and others, this volume). Deformed thrust faults occur within the Wales Group and along its contacts with the younger Moira Sound unit; thrust faults also cut the Cretaceous pluton at Mount Jumbo (Herreid and others, 1978; see Karl and others, this volume). These relations indicate that thrusting occurred during Ordovician and Cretaceous and, possibly, other tectonic events. High-angle faults cut all major units, including many Late Proterozoic and Devonian plutons. Major regional strike-slip faults of Tertiary age on the east side of Prince of Wales Island (for example, in Clarence Strait) record transform faulting between the Pacific and North American Plates, after Jurassic through Cretaceous accretion of the Alexander terrane to the inboard terranes of southeastern Alaska and coastal British Columbia (Karl and others, 1999; Nokleberg and others, 2001).

\section{Analytical Methods}

Whole-rock compositions of samples of massive and semimassive sulfide were obtained by XRAL Laboratories in Denver, Colo. Major and minor elements were analyzed by 
inductively coupled plasma atomic-emission spectrometry (ICP-AES) after acid digestion of powdered samples. Total $\mathrm{S}$ content was determined by Leco furnace methods, $\mathrm{As}, \mathrm{Sb}$, $\mathrm{Hg}$, Se, Te, and $\mathrm{Tl}$ contents by atomic-absorption spectrometry, and Au content by fire assay. Analytical results are not reported for $\mathrm{Nb}, \mathrm{Ta}, \mathrm{Cr}, \mathrm{Ba}, \mathrm{Sn}$, Th, Y, La, and $\mathrm{Ce}$, which typically concentrate in resistate heavy minerals (for example, rutile, chromite, barite, cassiterite, monazite), because a flux was not used in the ICP-AES analyses to ensure their complete dissolution; similarly, data for Ti may not be meaningful (that is, are too low) and should be viewed with caution.

Trace-element contents in sulfide minerals were determined by laser-ablation inductively coupled plasma mass spectrometry (LA-ICP-MS) at the U.S. Geological Survey (USGS) laboratory in Denver, Colo. This technique has the advantage of providing in situ analyses at low concentrations and high precision (for example, Watling and others, 1995; Ridley and Lichte, 1998; Butler and Nesbitt, 1999; Axelsson and Rodushkin, 2001). Polished thin sections were used for the LA-ICP-MS analyses to allow integration of the geochemical results with information on textures and mineral assemblages. Analyses were obtained for counting times of 5 minutes on 50- $\mu \mathrm{m}$-diameter spots, according to the methods of Ridley and Lichte (1998), using a synthetic sulfide standard, as described by Wilson and others (2002). Data reduction was done offline with GeoPro software (CETAC Technologies, 2000). This software program was used to select spectra that were unaffected by analysis of small mineral inclusions (for example, chalcopyrite in sphalerite), thus providing more robust data on the phase-specific trace-element contents of the sulfide minerals. Total analytical precision by the LAICP-MS method is estimated at 2 to 8 percent (Ridley, 2000; Norman and others, 2003).

Sulfur-bearing phases from mineralized samples were physically separated and analyzed for $\delta^{34} S$ values, using an automated elemental analyzer interfaced to an isotope-ratio mass spectrometer (Giesemann and others, 1994), at the USGS laboratory in Denver, Colo. The $\delta^{34} \mathrm{~S}$ values were calibrated to the Cañon Diablo troilite standard and are reported here in conventional permil notation; relative error is estimated at \pm 0.2 permil. Disseminated sulfides in unmineralized host rocks were separated in bulk, using the $\mathrm{CrCl}_{2}$ dissolution method of Tuttle and others (1986), which extracts all sulfide minerals. Barite from the Big Harbor West deposit (BHW, fig. 1) that is intergrown with fine-grained sulfides was separated by using the $\mathrm{NaCO}_{3}$ method of Breit and others (1985) to permit analysis of barite only and not also admixed sulfides.

\section{VMS Deposits}

\section{History and Production}

VMS deposits and occurrences in the study area are restricted to Late Proterozoic through Cambrian rocks of the
Wales Group and Silurian through Ordovician rocks of the Moira Sound unit (fig. 1; table 1). In this report, VMS deposits are distinguished from occurrences by evidence at the deposits of past mining development or mineral exploration (for example, trenching, core drilling). The largest known deposits are the Khayyam and nearby Stumble-On ore bodies in the Wales Group, at the head of McKenzie Inlet, which were mined from 1901 to 1907, producing 210,000 t of massive sulfide ore averaging 1.7 weight percent $\mathrm{Cu}, 9.6 \mathrm{ppm} \mathrm{Ag}$, and 1.9 ppm Au (Barrie, 1984; Barrie and Kyle, 1988). The Khayyam deposit (KY, fig. 1) has an additional estimated resource of $78,700 \mathrm{t}$ of massive sulfide averaging 2.9 weight percent $\mathrm{Cu}$, 0.8 weight percent $\mathrm{Zn}, 17 \mathrm{ppm} \mathrm{Ag}$, and $1.3 \mathrm{ppm} \mathrm{Au}$ (Maas and others, 1995). The Copper City Mine (CC, fig. 1) produced $77 \mathrm{t} \mathrm{Cu}, 146 \mathrm{~kg} \mathrm{Ag}$, and $10.6 \mathrm{~kg} \mathrm{Au}$ between 1903 and 1905; the Corbin Mine (CB, fig. 1) produced smaller amounts of $\mathrm{Cu}$ (9.7 t) and Ag (12 kg) during 1906-13 (Bufvers, 1967). The Niblack deposit (NL, fig. 1), in the Moira Sound unit on the north side of Moira Sound, was mined from 1902 to 1908 , producing 18,000 t of ore averaging 4.9 weight percent $\mathrm{Cu}, 34$ ppm Ag, and 2.3 ppm Au (Maas and others, 1995). Mineral exploration in the Niblack area from 1993 to 2006 has identified several more VMS deposits, including the Lookout Mountain deposit (LO, fig. 1), with an inferred resource of $2.52 \mathrm{Mt}$ averaging 3.22 weight percent $\mathrm{Zn}, 1.70$ weight percent $\mathrm{Cu}$, $36.4 \mathrm{~g} \mathrm{Ag} / \mathrm{t}$, and $2.77 \mathrm{~g} \mathrm{Au} / \mathrm{t}$. The nearby Dama (DM, fig. 1), Lindsy/88 (LS, fig. 1), and Trio/Broadgauge deposits contain significant amounts of $\mathrm{Zn}, \mathrm{Cu}, \mathrm{Ag}$, and $\mathrm{Au}$ in some drill holes (Adamson and Gray, 1995; Niblack Mining Corp., 2006, URL http://www.niblackmining.com/). Other VMS deposits on Prince of Wales Island and vicinity were not mined or have only minor reported production (Barrie and Kyle, 1988; Maas and others, 1995), estimated at no more than 500 t. During the 1990s, the Nutkwa deposits (NKM/NKN, fig. 1) were extensively explored and drilled, while the Big Harbor East and West, Copper City, Corbin, and Hozer deposits (BHE/BHW, $\mathrm{CC}, \mathrm{CB}$, and HZ, respectively, fig. 1) had only limited exploration and drilling.

\section{Deposits in the Wales Group}

The Khayyam and Stumble-On deposits (KY and SO, respectively, fig. 1) form elongate lenses of massive and semimassive sulfide, as much as $6 \mathrm{~m}$ thick and at least $170 \mathrm{~m}$ long, within amphibolite-facies metavolcanic and metasedimentary rocks of the Wales Group (Fosse, 1946; Barrie, 1984; Barrie and Kyle, 1988). Major host rocks at and near these deposits include mafic and felsic schist and gneiss, intermediate-composition schist, and siliceous schist. Lenses of amphibolite and large bodies of both foliated and unfoliated diorite occur in the area. Thin ( $<1 \mathrm{~cm}$ thick) beds of coticule (spessartine quartzite) are also present in some felsic schist and gneiss. Sulfide minerals are clearly recrystallized by postore regional metamorphism, typically forming a mixture of euhedral and granoblastic grains in which coarse-grained to very coarse grained ( $>1 \mathrm{~cm}$ diam) pyrite occurs within a matrix of chalco- 
Table 1. Data for volcanogenic massive sulfide deposits and occurrences on southern Prince of Wales Island and vicinity, southeastern Alaska.

[Numbered Barrier Islands occurrences correspond to locations in Gehrels and others (1983). Longitudes in parentheses are approximate. Host rocks, listed in decreasing order of abundance: amp, amphibolite; bas, basalt or metabasalt (including greenstone, andesite, and chlorite schist); bs, black shale and slate; cht, chert or metachert; cot, coticule; dol, dolomite; fels, felsic schist and gneiss (including quartz-sericite schist and volcaniclastic sedimentary rocks); gab, gabbro or metagabbro (including diorite and quartz diorite); grn, granite; grw, graywacke; if, iron-formation; jas, jasper; mbl, marble; phy, phyllite; rhy, rhyolite or metarhyolite (including tuff, breccia, and conglomerate); sh, shale and slate (including argillite). Principal metals are listed in decreasing order of concentration in production records or chemical analyses (Maas and others, 1995; this study). Opaque minerals, listed in decreasing order of abundance: asp, arsenopyrite; bn, bornite; cp, chalcopyrite; gl, galena; mt, magnetite; po, pyrrhotite; py, pyrite; sl, sphalerite]

\begin{tabular}{|c|c|c|c|c|c|c|}
\hline $\begin{array}{l}\text { Deposit or occurrence } \\
\text { (fig. 1) }\end{array}$ & $\begin{array}{l}\text { Latitude } \\
\left({ }^{\circ} \mathrm{N} .\right)\end{array}$ & $\begin{array}{c}\text { Longitude } \\
\left({ }^{\circ} \mathrm{W} .\right)\end{array}$ & $\begin{array}{l}\text { Host } \\
\text { rocks }\end{array}$ & $\begin{array}{l}\text { Principal } \\
\text { metals }\end{array}$ & $\begin{array}{l}\text { Opaque } \\
\text { minerals }\end{array}$ & Major reference \\
\hline \multicolumn{7}{|c|}{ Wales Group } \\
\hline 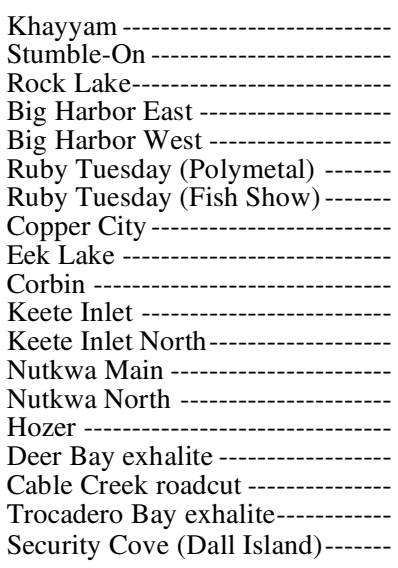 & $\begin{array}{l}55.29861 \\
55.29583 \\
55.30833 \\
55.37611 \\
55.37556 \\
55.21667 \\
155.22167 \\
55.13417 \\
55.17042 \\
55.23139 \\
55.08111 \\
55.10986 \\
55.07653 \\
55.08681 \\
55.04000 \\
55.26917 \\
55.35179 \\
55.35849 \\
54.75000\end{array}$ & $\begin{array}{l}132.38611 \\
132.37222 \\
132.50000 \\
132.95361 \\
132.96389 \\
132.32278 \\
132.33528 \\
132.60944 \\
132.67375 \\
132.64861 \\
132.48889 \\
132.47561 \\
132.55128 \\
132.54153 \\
132.54250 \\
132.66667 \\
132.83060 \\
132.82680 \\
132.85694\end{array}$ & $\begin{array}{l}\text { fels, amp, gab, cot } \\
\text { fels, amp, gab } \\
\text { fels, amp } \\
\text { fels, bas, sh } \\
\text { bas, fels, sh } \\
\text { fels, bas, cht, mbl } \\
\text { fels, bas, cht, mbl } \\
\text { rhy, phy, bas, if, jas } \\
\text { rhy, fels, bas } \\
\text { fels, rhy, phy } \\
\text { fels, rhy, bas, if } \\
\text { fels, rhy, bas } \\
\text { rhy, fels, bas } \\
\text { rhy, fels, bas } \\
\text { fels, rhy, bas } \\
\text { fels, bas, phy } \\
\text { fels, phy, bas } \\
\text { fels } \\
\text { fels, bas, mbl }\end{array}$ & $\begin{array}{l}\mathrm{Cu}, \mathrm{Zn}, \mathrm{Ag}, \mathrm{Au} \\
\mathrm{Cu}, \mathrm{Zn}, \mathrm{Ag}, \mathrm{Au} \\
\mathrm{Cu}, \mathrm{Zn}, \mathrm{Au} \\
\mathrm{Cu}, \mathrm{Ag}, \mathrm{Au} \\
\mathrm{Cu}, \mathrm{Zn}, \mathrm{Ag}, \mathrm{Au} \\
\mathrm{Zn}, \mathrm{Pb}, \mathrm{Cu}, \mathrm{Ag} \\
\mathrm{Zn}, \mathrm{Pb}, \mathrm{Cu}, \mathrm{Ag} \\
\mathrm{Cu}, \mathrm{Zn}, \mathrm{Ag}, \mathrm{Au} \\
\mathrm{Cu} \\
\mathrm{Cu}, \mathrm{Zn}, \mathrm{Ag}, \mathrm{Au} \\
\mathrm{Cu}, \mathrm{Zn}, \mathrm{Ag}, \mathrm{Au} \\
\mathrm{Cu}, \mathrm{Zn}, \mathrm{Ag}, \mathrm{Au} \\
\mathrm{Zn}, \mathrm{Cu}, \mathrm{Pb}, \mathrm{Ag} \\
\mathrm{Zn}, \mathrm{Cu}, \mathrm{Pb}, \mathrm{Ag} \\
\mathrm{Zn}, \mathrm{Cu} \\
\mathrm{Cu}, \mathrm{Zn}, \mathrm{Ag}, \mathrm{Au} \\
\mathrm{Cu}, \mathrm{Zn}, \mathrm{Ag}, \mathrm{Au} \\
\mathrm{None} \text { identified } \\
\mathrm{Zn}, \mathrm{Pb}, \mathrm{Ag}, \mathrm{Ba}\end{array}$ & $\begin{array}{l}\text { py, cp, sl, po, asp, mt } \\
\text { py, cp, sl, po, asp, mt } \\
\text { py, cp, sl, mt } \\
\text { py, cp } \\
\text { py, cp, sl } \\
\text { py, sl, gl, cp } \\
\text { py, sl, gl, cp } \\
\text { py, cp, sl, gl, mt } \\
\text { py, cp } \\
\text { py, cp, sl } \\
\text { py, cp, sl, bn, mt } \\
\text { py, cp, sl } \\
\text { py, sl, cp, gl } \\
\text { py, sl, cp, gl } \\
\text { py, sl, cp } \\
\text { py, cp, sl } \\
\text { py, sp, sl } \\
\text { py } \\
\text { py, sl, gl, cp }\end{array}$ & $\begin{array}{l}\text { Barrie and Kyle (1988). } \\
\text { Do. } \\
\text { Barrie (1984). } \\
\text { Maas and others (1995). } \\
\text { Do. } \\
\text { Kucinski (1987). } \\
\text { Maas and others (1995). } \\
\text { Thurston (1994). } \\
\text { Casselman and Bohme (1997). } \\
\text { Thurston (1994). } \\
\text { Maas and others (1991). } \\
\text { Do. } \\
\text { Casselman and Bohme (1997). } \\
\text { Do. } \\
\text { Maas and others (1991). } \\
\text { Maas and others (1995). } \\
\text { Do. } \\
\text { Do. } \\
\text { Maas and others (1995). }\end{array}$ \\
\hline \multicolumn{7}{|c|}{ Moira Sound unit and correlatives } \\
\hline 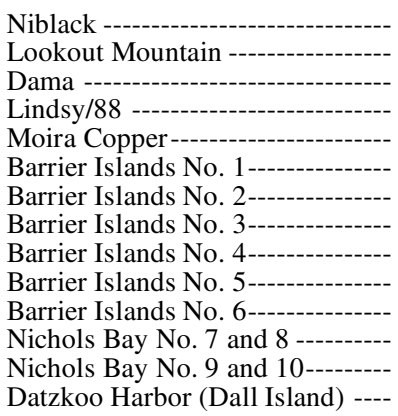 & $\begin{array}{r}55.06667 \\
55.05639 \\
55.05389 \\
55.06306 \\
55.07644 \\
54.81222 \\
54.80139 \\
54.81000 \\
54.79722 \\
54.80389 \\
54.79722 \\
54.70237 \\
{ }^{2} 54.73514 \\
54.74056\end{array}$ & $\begin{array}{l}132.14639 \\
132.14139 \\
132.12528 \\
132.13833 \\
132.17987 \\
132.44889 \\
132.45464 \\
132.49472 \\
132.45056 \\
132.39167 \\
132.33833 \\
132.11715 \\
132.14154 \\
132.74944\end{array}$ & $\begin{array}{l}\text { rhy, bas, if, jas, cht } \\
\text { rhy, bas } \\
\text { rhy, bas } \\
\text { rhy, bas } \\
\text { rhy, bas } \\
\text { bas, rhy, bs } \\
\text { rhy, bas } \\
\text { rhy, bas } \\
\text { rhy, bs, bas, dol } \\
\text { rhy, gab } \\
\text { bs, rhy } \\
\text { rhy, bas } \\
\text { grw, bs, rhy, grn } \\
\text { fels, bas }\end{array}$ & $\begin{array}{l}\mathrm{Cu}, \mathrm{Zn}, \mathrm{Ag}, \mathrm{Au} \\
\mathrm{Zn}, \mathrm{Cu}, \mathrm{Ag}, \mathrm{Au} \\
\mathrm{Zn}, \mathrm{Cu}, \mathrm{Ag}, \mathrm{Au} \\
\mathrm{Zn}, \mathrm{Cu}, \mathrm{Ag}, \mathrm{Au} \\
\mathrm{Cu}, \mathrm{Ag}, \mathrm{Au} \\
\mathrm{Zn}, \mathrm{Ba} \\
\mathrm{Zn}, \mathrm{Pb}, \mathrm{Ag} \\
\text { None identified } \\
\text { None identified } \\
\text { None identified } \\
\text { None identified } \\
\text { None identified } \\
\mathrm{Zn}, \mathrm{Ag} \\
\mathrm{Zn}, \mathrm{Ag}, \mathrm{Ba}\end{array}$ & $\begin{array}{l}\text { py, cp, sl } \\
\text { py, sl, cp } \\
\text { py, sl, cp } \\
\text { py, sl, cp } \\
\text { py, cp, mt } \\
\text { py, sl } \\
\text { py, sl, gl } \\
\text { py } \\
\text { py } \\
\text { py } \\
\text { py } \\
\text { py } \\
\text { po, py, sl, mt } \\
\text { py, sl }\end{array}$ & $\begin{array}{l}\text { Peek (1975). } \\
\text { Niblack Mining Corp (2006). } \\
\text { Adamson and Gray (1995). } \\
\text { Do. } \\
\text { Wright and Wright (1908). } \\
\text { Gehrels and others (1983). } \\
\text { Do. } \\
\text { Do. } \\
\text { Do. } \\
\text { Do. } \\
\text { Do. } \\
\text { Do. } \\
\text { Do. } \\
\text { Maas and others (1995). }\end{array}$ \\
\hline
\end{tabular}

${ }^{1}$ Includes the nearby Chomly deposit $\sim 500 \mathrm{~m}$ to the west (Kucinski, 1988; Maas and others, 1995).

${ }^{2}$ These small deposits occur within the contact aureole of a Silurian(?) granite (see Karl and others, this volume). 
pyrite, pyrrhotite, and (or) sphalerite (figs. $2 A, 2 B, 3 A$ ). Some samples contain abundant granoblastic sphalerite, especially at the Stumble-On deposit (fig. 2C); pyrrhotite is common at both deposits. Among all the VMS deposits on Prince of Wales Island and vicinity, the Khayyam and Stumble-On deposits have the coarsest grained sulfide minerals.

Massive sulfides at the Corbin deposit (CB, fig. 1) occur within a deformed sequence of lower-greenschist-facies rhyolitic tuff and tuffaceous sedimentary rocks (Wright and Wright, 1908; Maas and others, 1995). A schist unit containing distinctive pink piemontite (Mn-epidote) is locally present in the footwall (Thurston, 1994; Hattie and others, 1996). The sulfide ore body is as much as $1 \mathrm{~m}$ thick and at least 75 $\mathrm{m}$ long. Detailed surface and underground mapping reported by Thurston (1994) reveals complex structures within the massive sulfides, including isoclinal folds and shear zones. Massive granoblastic pyrite is widespread, accompanied by varying amounts of chalcopyrite and sphalerite that in places define a conspicuous mineralogic layering (fig. $3 B$ ).

VMS deposits in the Big Harbor area (fig. 1) occur in two main areas on the north side of Trocadero Bay (Chapin, 1916; Twenhofel and others, 1949). The deposits are within a greenschist-facies sequence of tightly folded quartz-sericite schist, metabasaltic greenstone, and dacitic tuff that are spatially associated with an elongate body of feldspar porphyry (Terry and Gibson, 1998). The Big Harbor East deposit (BHE, fig. 1) consists mainly of siliceous pyritic sulfide, as much as $9 \mathrm{~m}$ thick, containing varying amounts of matrix chalcopyrite and minor sphalerite and sericite. About $750 \mathrm{~m}$ to the west, the Big Harbor West deposit (BHW, fig. 1) forms a nearly 1-m-thick stratiform lens of massive chalcopyrite and minor pyrite and sphalerite (fig. $3 C$ ) within greenstone and quartz-sericite schist. A thin stratiform unit about $150 \mathrm{~m}$ to the north, composed of Mn-calcite and spessartine garnet, minor quartz, barite, magnetite, and galena, and sparse sphalerite and chalcopyrite, probably represents an exhalative chemical sediment in the upper hanging-wall sequence (Terry and Gibson, 1998).

The small Keete Inlet deposit (KI, fig. 1) consists of massive siliceous pyritic sulfide with minor chalcopyrite, sphalerite, and rare bornite, hosted in metarhyolitic tuff and metabasaltic greenstone (Chapin, 1916; Maas and others, 1991). Massive sulfide layers are as much as $0.6 \mathrm{~m}$ thick. Common textures show granoblastic pyrite within a matrix of fine-grained chalcopyrite and sphalerite (figs. $2 D, 3 D$ ). A thin unit of magnetite iron-formation, which occurs in shoreline outcrops several hundred meters south of the deposit (see Karl and others, this volume), may be related to the sulfide mineralization. Metamorphic grade in the area is lower to middle greenschist facies. A similar but smaller VMS occurrence, here designated Keete Inlet North (KIN, fig. 1), is about $3.4 \mathrm{~km}$ north-northeast of the main deposit (Maas and others, 1991).

The Copper City (also known as Red Wing) deposit (CC, fig. 1) consists of a massive sulfide layer, as much as 2 $\mathrm{m}$ thick and nearly $100 \mathrm{~m}$ long, within a sequence of mainly felsic metavolcanic and metasedimentary rocks (Wright and Wright, 1908; Herreid and others, 1978). Footwall strata are composed of sericite-altered metarhyolite and metadacite with thin interbeds of mafic metatuff; the hanging wall contains jasper, magnetite iron-formation, and ferruginous micaceous phyllite (Wright and Wright, 1908; Thurston, 1994; Maas and others, 1995). Thurston (1994) and Forbes and others (1995) also reported a 0.3-m-thick pink layer in the hanging wall that contains abundant piemontite. Sulfide minerals consist mainly of pyrite and chalcopyrite, minor sphalerite, and rare galena (figs. $2 E, 3 E$ ). As much as 6,700 ppm Ba occurs in some sulfide-rich samples (Maas and others, 1995, table A-2), but whether this element resides in minor barite or in Ba-feldspar or mica is unknown. To the northwest, across Hetta Inlet, the Eek Lake occurrence (EL, fig. 1) is a small lens, less than $0.3 \mathrm{~m}$ thick, composed of pyrite and abundant chalcopyrite within altered felsic metavolcanic rocks (Casselman and Bohme, 1997).

The only true polymetallic VMS deposits on Prince of Wales Island and vicinity (fig. 1) are in the Ruby Tuesday area. Several VMS deposits have been identified here, including the Chomly, Fish Show, and Polymetal; the first two (RTF, fig. 1) are about $1.5 \mathrm{~km}$ west-northwest and 1 $\mathrm{km}$ northwest, respectively, of the Polymetal deposit (RTP, fig. 1; Fowler, 1949; Kucinski, 1987; Maas and others, 1995). The deposits occur at two or, possibly, three different stratigraphic levels, in a folded and faulted volcanosedimentary sequence with a lower-greenschist-facies metamorphic overprint. The Polymetal deposit is in locally fragmental felsic volcaniclastic schist, whereas the Chomly and Fish Show deposits are in siliceous graphitic argillite. Metabasaltic greenstone and marble also occur in parts of the Ruby Tuesday area (Kucinski, 1987). Massive sulfide from the Fish Show deposit is noteworthy in containing conspicuous volcanic clasts within a matrix of fine-grained sphalerite, galena, pyrite, and minor chalcopyrite (figs. $2 F, 3 F$ ).

Two main areas of massive sulfide are known in the Nutkwa area (Nutkwa Main and North deposits; NKM/NKN, fig. 1), west of the Keete Inlet deposit (KI, fig. 1). The Nutkwa deposits occur in a sequence of lower-greenschistfacies, dacitic to rhyolitic volcanic rocks and volcaniclastic sedimentary rocks, together with varying amounts of metabasaltic greenstone (Hattie and others, 1996; Casselman and Bohme, 1997). Massive sulfides at both deposits are in stratiform layers, 0.3 to $1.5 \mathrm{~m}$ thick. On the basis of outcrop distribution and drill-hole intersections, the Nutkwa Main and North deposits have strike lengths of 430 and $400 \mathrm{~m}$, respectively, and are believed to represent the same stratigraphic horizon (Hattie and others, 1996). Pyrite and abundant fine-grained sphalerite are the dominant sulfides, together with minor chalcopyrite and sparse galena. A clastic texture is characteristic of the Nutkwa Main deposit, in which fragments of chlorite schist, sericite schist, and quartz occur within a pyrite- and sphalerite-rich matrix. The presence of as much as 1.8 weight percent $\mathrm{Ba}$ in drill cores at the Nutkwa North deposit (Hattie and others, 1996) suggests the 

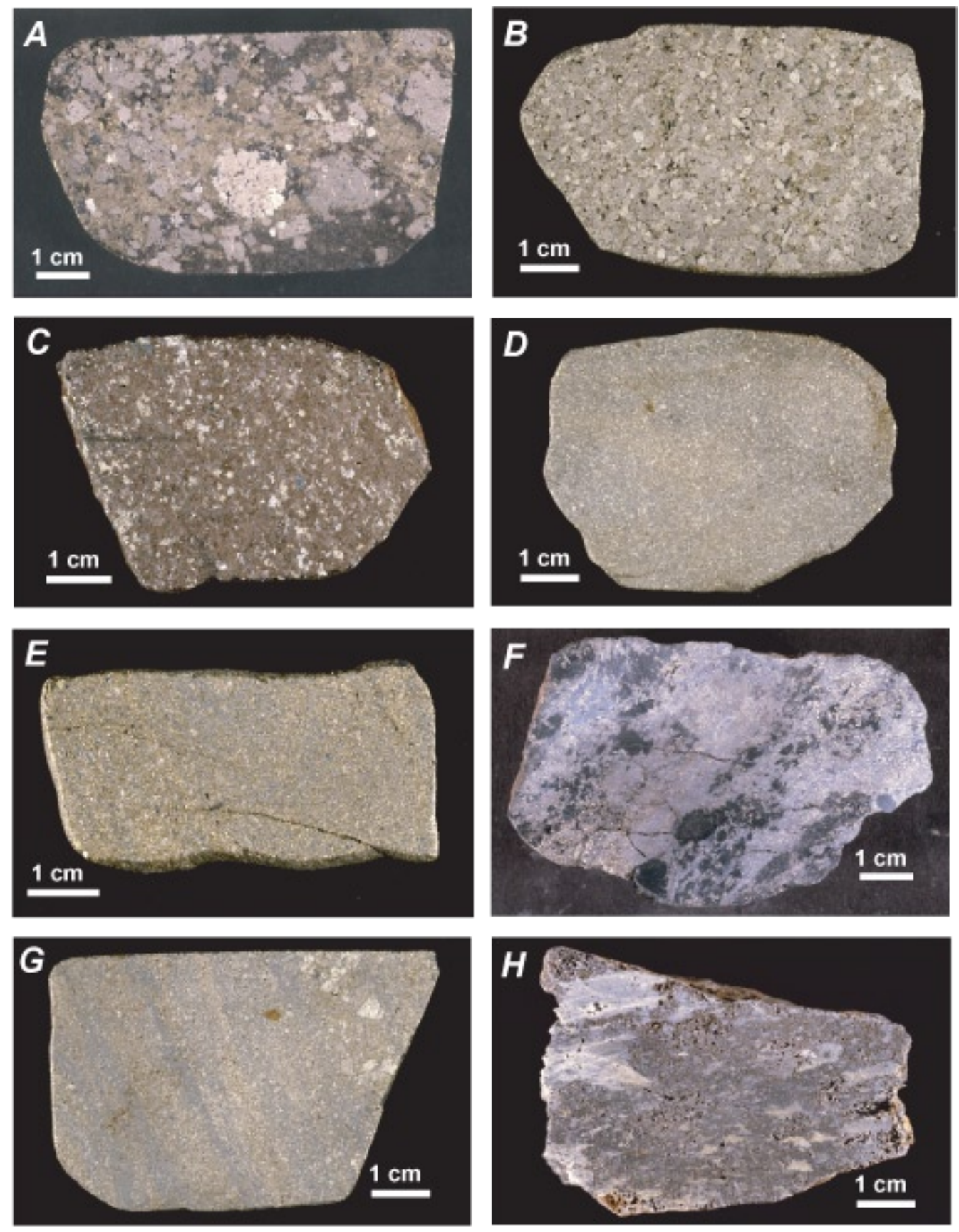

Figure 2. Representative sulfide-rich samples from volcanogenic massive sulfide deposits in study area (fig. 1). $A$, Very coarse grained porphyroblastic pyrite in a matrix of chalcopyrite, pyrrhotite (partially altered to marcasite), and minor sphalerite. Stumble-On Mine dump, sample JS-00-36A. B, Coarsegrained granoblastic pyrite within a matrix of fine-grained chalcopyrite and minor sphalerite. Khayyam Mine upper dump, sample JS-00-62A. C, Coarse-grained disseminated pyrite (minor) within a matrix of coarse-grained, granular sphalerite (abundant). Stumble-0n Mine dump, sample JS-00-36C. D, Pyritic massive sulfide with minor interstitial sphalerite and trace chalcopyrite. Keete Inlet Mine dump, sample JS-00-53A. E, Massive chalcopyrite and sphalerite with minor pyrite. Copper City Mine dump, sample JS-00-55A. F, High-grade polymetallic massive sulfide with abundant sphalerite and galena, and minor chalcopyrite, and relict volcanic clasts (dark). Ruby Tuesday (Fish Show) Mine dump, sample RT-FS-MS. $G$, Layered pyrite, sphalerite, minor chalcopyrite, with local coarse-grained pyrite (right). Dama deposit, sample L0-53/624.2. H, Pyrite and sparse galena with sericite-rich rhyolite lapilli(?). Barrier Islands No. 2 occurrence, sample BI-2-MS. 

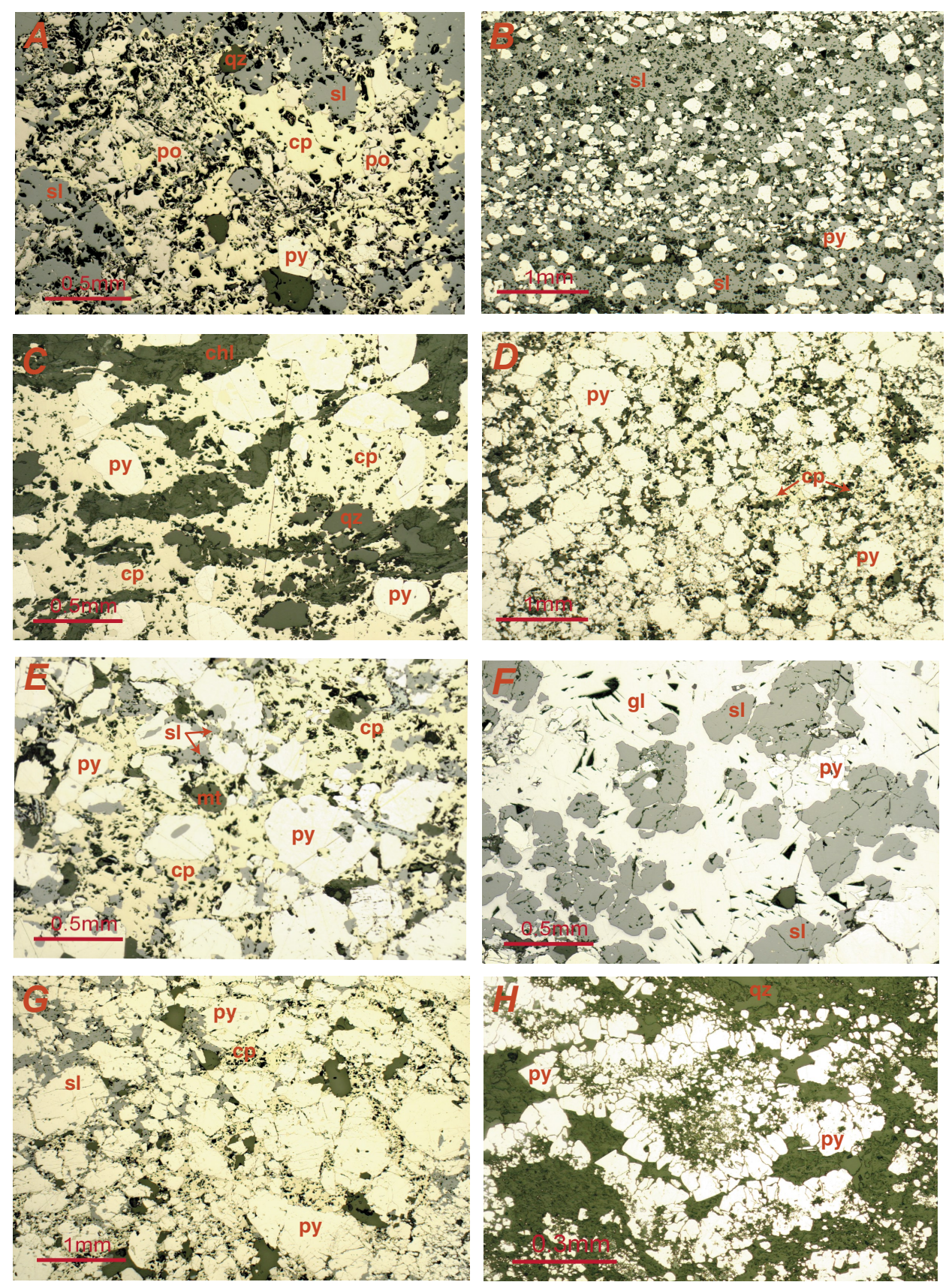

Figure 3. Photomicrographs (all in reflected light) of sulfide-rich samples from the study area (fig. 1). Minerals: chl, chlorite; $c p$, chalcopyrite; gl, galena; mt, magnetite; po, pyrrhotite; py, pyrite; qz, quartz; sl, sphalerite. $A$, Abundant pyrrhotite intergrown with chalcopyrite, sphalerite, and minor pyrite and quartz. Stumble-0n Mine dump, sample JS-00-36D. $B$, Layers of sphalerite- and pyrite-rich massive sulfide. Corbin Mine dump, sample JS-00-56l. $C$, Chalcopyrite and coarse-grained pyrite within a matrix of foliated chlorite and quartz. Big Harbor West deposit, sample JS-00-31C. D, Coarse-grained pyrite within a matrix of finegrained chalcopyrite, quartz, and minor sphalerite. Keete Inlet Mine dump, sample JS-00-53A. $E$, Coarse-grained pyrite within a matrix of chalcopyrite and minor sphalerite and magnetite. Copper City Mine dump, sample JS-00-55C. F, Intergrowths of sphalerite and galena with minor pyrite. Ruby Tuesday (Fish Show) deposit, sample RT-FS-MS. G, Granular pyrite within a matrix of fine-grained sphalerite, chalcopyrite, and quartz. Dama deposit, sample LO-53/624.2. $H$, Fine-grained anhedral and coarse-grained euhedral pyrite in quartz. Barrier Islands No. 2 occurrence, sample BI-2-MS. 
presence of barite, although this element could also reside in Ba-rich feldspar and (or) mica. The deposit contains zones of abundant Mn oxides, as much as $1 \mathrm{~m}$ thick (Hattie and others, 1996).

The small Hozer deposit (HZ, fig. 1) occurs south of the Nutkwa deposits on the south side of Keete Inlet. Host rocks are mainly felsic schist, quartz-rich metatuff, and greenstone breccia, all of which are metamorphosed to lower-greenschist-facies assemblages. Sulfides consist of disseminated pyrite, minor sphalerite, and sparse chalcopyrite, together with stringers and veinlets of pyrite; no massive sulfide is known from the area (Maas and others, 1991). This mineralized sequence may be part of the same stratigraphic section that contains the Nutkwa deposits to the north.

Four small stratiform sulfide occurrences in the Wales Group probably represent exhalative VMS deposits. Such exhalites are believed to form by chemical precipitation of sulfide and other minerals from hydrothermal plumes distal from high-temperature sea-floor vent sources (for example, Spry and others, 2000). The Deer Bay exhalite (DB, fig. 1), on the west side of Hetta Inlet, consists of disseminated pyrite, minor chalcopyrite, and sparse sphalerite in a pyritic quartz-sericite-chlorite schist (Maas and others, 1995). To the northwest, the Cable Creek roadcut occurrence (CCR, fig. 1; Maas and others, 1995) contains disseminated to semimassive pyrite with minor sphalerite and chalcopyrite; barren pyritic schist to the east, termed the "Trocadero Bay exhalite," is probably a lateral facies equivalent. A similar sulfide occurrence at Security Cove (SC, fig. 1), on the southwest side of Dall Island, consists of thin $(<20 \mathrm{~cm}$ thick) layers of massive pyrite and locally abundant sphalerite and galena with sparse chalcopyrite; accessory barite is implied by the presence of as much as 2.3 weight percent Ba (Berg, 1984; Maas and others, 1995).

One stratabound barite deposit is known on the south end of the Lime Point peninsula (fig. 1). Although it lacks associated sulfide minerals, the Lime Point deposit (LP, fig. 1) is important metallogenically because it occurs in the same metavolcanic and metasedimentary sequence that hosts the Copper City ore body $8 \mathrm{~km}$ to the north (CC, fig. 1; Maas and others, 1995). The Lime Point deposit differs, however, in being localized within a unit of calcite marble and minor interbedded talc schist. Barite there consists of massive, essentially pure bodies, 3 to $12 \mathrm{~m}$ thick and $\sim 30 \mathrm{~m}$ long, that are discordant to bedding in the host marble (Elmendorf, 1920; Fowler, 1948; Twenhofel and others, 1949). In outcrop and underground in the adit, the barite shows abundant evidence of an early, pretectonic replacement of the precursor limestone, including the presence of tightly folded barite lenses in marble. It is unknown, however, whether this barite formed mainly on the sea floor contemporaneously with carbonate sediment, as a broadly synsedimentary (early diagenetic) replacement of limestone, like some stratabound barite deposits elsewhere (for example, Ketner, 1975; Ahsan and Mallick, 1999; Kelley and others, 2004), or as a late diagenetic replacement deep in the subsurface.

\section{Deposits in the Moira Sound Unit and Correlatives}

Several VMS deposits are known in the Niblack anchorage area (fig. 1; table 1). Massive sulfides and local stringer sulfides there occur in a sequence composed dominantly of felsic metavolcanic and tuffaceous metasedimentary rocks that traditionally have been assigned to the Wales Group (for example, Peek, 1975; Gehrels and Berg, 1992; Maas and others, 1995). These assignments are supported by a U-Pb zircon age of $595 \pm 20$ m.y. determined by Gehrels and others (1996) on a massive rhyolite at Lookout Mountain. This Late Proterozoic age is inconsistent, however, with various geologic data which suggest that the host rocks of these VMS deposits belong to the younger Moira Sound unit and not to the older Wales Group (see Karl and others, this volume).

The Niblack deposit (NL, fig. 1) consists of a series of irregular lenses of massive sulfide, as much as $9 \mathrm{~m}$ thick and 60 $\mathrm{m}$ long, within a host sequence of tuffaceous metarhyolite and minor interbedded clastic sedimentary rocks (Brooks, 1902; Wright and Wright, 1908; Herreid, 1964; Peek, 1975). Footwall rocks stratigraphically below the mineralized sequence comprise metadacite and metabasaltic greenstone; hangingwall rocks above this sequence consist largely of metabasalt (Niblack Mining Corp., 2006, URL http://www.niblackmining. $\mathrm{com} /$ ). Regional metamorphic grade is lower greenschist facies. The massive sulfides consist of pyrite and chalcopyrite, generally minor sphalerite, and sparse galena. Disseminated and stringer sulfides also occur nearby, the stringers probably representing part of a footwall feeder zone to the massive sulfides stratigraphically above. Related hydrothermal sedimentary rocks present in the mine area include jasper, magnetite ironformation, metachert, and quartz-piemontite-spessartine (Peek, 1975; Adamson and Gray, 1995).

Several other significant VMS deposits occur in the Niblack area, the largest of which is the Lookout Mountain deposit (LO, fig. 1), about 1,300 m south-southeast of the Niblack Mine (NL, fig. 1). Host rocks to this deposit consist of a deformed sequence of pyritic rhyolite metatuff that locally contains sulfide-rich clasts; a Mn-rich piemontite-spessartine-rhodonite layer occurs in the stratigraphic hanging wall (Adamson and Gray, 1995). Footwall rocks are mainly metabasaltic amygdaloidal greenstone that in places displays relict pillow structures. The massive sulfides on Lookout Mountain form three stacked lenses separated by zones of disseminated and stringer sulfides with an aggregate thickness of about $60 \mathrm{~m}$; individual massive sulfides lenses are as much as $14 \mathrm{~m}$ thick (Green, 2006; Niblack Mining Corp., 2006, URL http://www.niblackmining.com/). Comparable thicknesses of mineralized rock have been intersected in drilling at the nearby Dama (DM, fig. 1), Lindsy/88 (LS, fig. 1), and Trio/Broadgauge deposits (Adamson and Gray, 1995). In all of these deposits, pyrite is the chief sulfide mineral, accompanied by varying amounts of sphalerite and chalcopyrite with appreciable gold in places. The sulfides form massive zones and seams within strongly sericite altered rhyolite tuff or, less 
commonly, alternating layers composed dominantly of pyrite and sphalerite (fig. $2 G$ ). Some samples show relatively coarse grained pyrite with interstitial sphalerite and chalcopyrite (figs. $2 G, 3 G$ ).

The Moira Copper deposit (MC, fig. 1), also known as the Wakefield group of claims (Wright and Wright, 1908; Maas and others, 1995), occurs about $2 \mathrm{~km}$ west-northwest of the Niblack Mine (NL, fig. 1). This small VMS deposit forms a lens of sulfides, as much as $3 \mathrm{~m}$ thick, within a sequence of metabasaltic greenstone and metarhyolitic rocks that also includes interbedded volcaniclastic sedimentary rocks. Similar to the deposits in the Niblack area, the Moira Copper deposit is hosted in weakly deformed rocks that have been regionally metamorphosed to lower greenschist facies. The sulfide body consists of semimassive pyrite and chalcopyrite with trace sphalerite.

Small VMS deposits and occurrences are known in several places along the southwest and south ends of Prince of Wales Island (fig. 1). Dominantly volcanic and lesser sedimentary host rocks in these areas are correlated with the Moira Sound unit by Karl and others (this volume). Occurrences on the Barrier Islands are mainly within rhyolitic tuff and siliceous black slate and are surrounded by a sequence composed dominantly of pillow basalt and pyroclastic breccia (Gehrels and others, 1983); rhyolite domes are present locally. Thin stratiform lenses of barren semimassive to massive pyrite are common, associated with lenses of sericite schist (fig. $2 H$ ). Textures of the pyrite are distinctive and differ from those in all other VMS deposits of the region, in which aggregates of fine-grained anhedral pyrite and rare framboidal pyrite are intergrown with coarse-grained euhedral pyrite (fig. $3 H$ ). Some sulfide-rich samples include sparse sphalerite and chalcopyrite and traces of galena. One pyritic lens in black slate at the Barrier Islands No. 1 deposit (BI-1, fig. 1) contains $>5,000$ ppm Ba (Gehrels and others, 1983, table 1), probably in barite or Ba-rich mica.

VMS deposits and occurrences are also known in the Nichols Bay area (fig. 1), the largest of which, at the northeast end of the bay, is the Nichols Bay Shaft deposit (NB, fig. 1; Chapin, 1918; Gehrels and others, 1983; Maas and others, 1995). Host rocks consist of interbedded slate, graywacke, and siliceous volcanic rocks, including chert. This deposit is within the contact aureole of a large granitic pluton of Devonian or Silurian age (Gehrels, 1992; see Karl and others, this volume). Sulfides form lenses and layers, several centimeters thick, composed of pyrite, pyrrhotite, minor sphalerite and magnetite, and sparse chalcopyrite; garnet porphyroblasts also occur in the massive sulfide. Other VMS occurrences in the Nichols Bay area are small and consist chiefly of pyrite with trace sphalerite (Gehrels and others, 1983; Maas and others, 1995).

A small VMS occurrence on the southeast side of Dall Island at Datzkoo Harbor (DH, fig. 1) consists of thin $(<10 \mathrm{~cm}$ thick) lenses within quartz-sericite phyllite of probable felsic volcanic or volcaniclastic origin, associated with hornblende schist, talc schist, and felsic schist (Maas and others, 1995). Metamorphic grade is upper greenschist or, possibly, lower amphibolite facies. The sulfide lenses are composed almost wholly of coarse-grained pyrite with only sparse sphalerite and trace chalcopyrite. Accessory barite is suggested by the presence of 1.3 weight percent $\mathrm{Ba}$ in one sample analyzed by Maas and others (1995).

\section{Bulk Geochemistry of Sulfide-Rich Samples}

\section{Sampling and Data Compilation}

The limited number of samples collected during this study provides only a reconnaissance coverage of VMS deposits in the region. Although care was taken to obtain representative samples from mine dumps, adits, and drill cores, these samples do not necessarily reflect the true mineralogic and chemical variations in a given deposit, especially in mine dumps that were previously sampled-some extensively-by earlier workers. Moreover, before 1910 and the widespread use of froth-flotation technology for efficiently separating $\mathrm{Zn}$ from $\mathrm{Cu}$ and $\mathrm{Pb}$ in polymetallic ores, sphalerite commonly was not recovered; sphalerite also was a penalty in the ores during smelting. Thus, a disproportionate amount of this mineral may have been left on the mine dumps during early mining operations.

For compilation purposes here, geochemical data for base and precious metals acquired during this study are combined with those of Maas and others (1995, table A-2) and several exploration and mining company reports. The mining-company data were obtained in the 1980 s and 1990s on a diverse suite of sulfide-rich samples from mine dumps, underground workings, and drill cores. Because of proprietary issues, these data are not individually cited here but, instead, are included with those of Maas and others (1995) and this study to permit calculation of more meaningful averages for $\mathrm{Cu}, \mathrm{Zn}, \mathrm{Pb}, \mathrm{Ag}$, and $\mathrm{Au}$ contents in the deposits under consideration.

\section{Base and Precious Metals}

Average base- and precious-metal contents in the major VMS deposits of the study area (fig. 1) are listed in table 2, and representative analyses of individual samples are listed in table 3 (Wales Group) and table 4 (Moira Sound unit). Overall, the sulfide-rich ( $>10$ volume percent) samples contain proportionately much more $\mathrm{Cu}$ and $\mathrm{Zn}$ than $\mathrm{Pb}$ (fig. $4 A$ ). Elemental data in samples from the VMS deposits in the Wales Group deposits display a similar distribution to those from the Moira Sound unit, which are dominated by more $\mathrm{Zn}$ rich bulk compositions. We note, however, that this difference may be only an artifact of sampling density. The maximum average $\mathrm{Pb}$ content was measured in samples from the Ruby Tuesday (Fish Show) deposit (table 2). One relatively $\mathrm{Pb}$ rich sample from the Nutkwa North deposit (NKN, fig. 1), in the Wales 
$A$ $\mathrm{Cu}$ (wt pct)

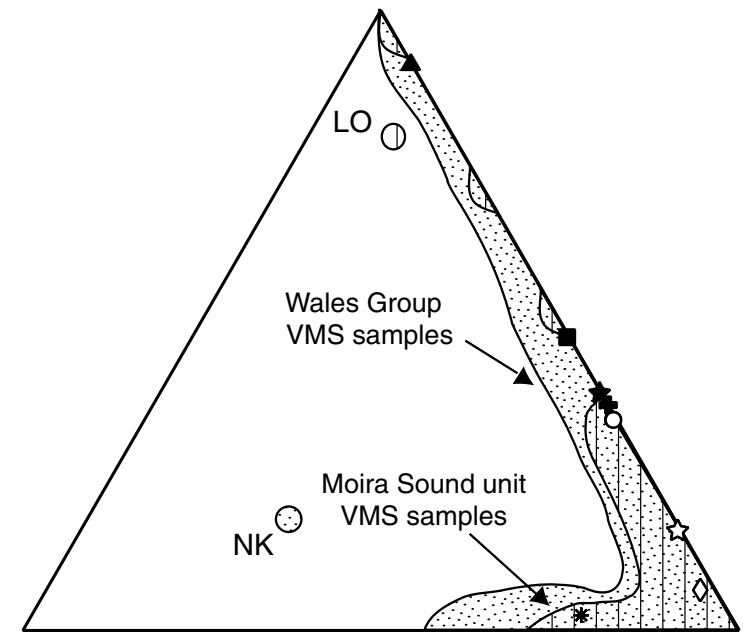

$\mathrm{Pb}$ (wt pct)

Zn (wt pct)

$B$

$\mathrm{Au}(\mathrm{ppm})$

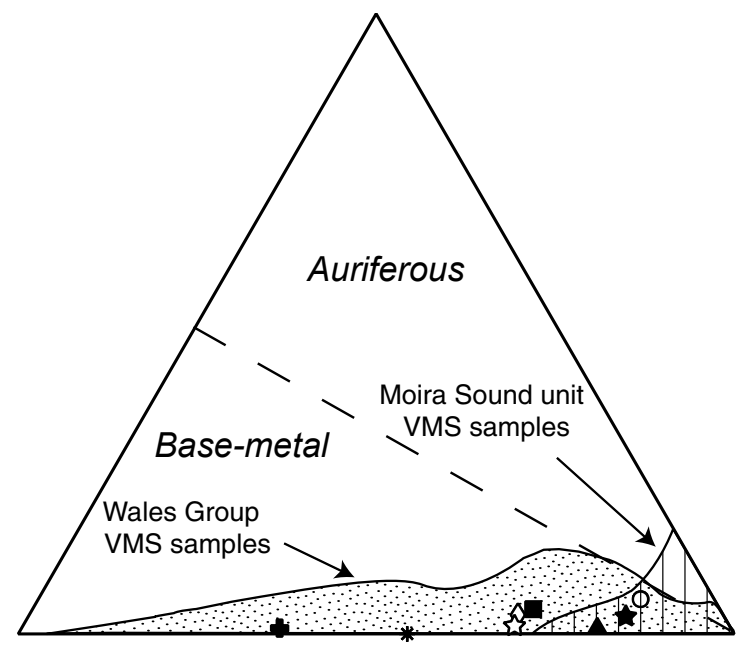

$\mathrm{Cu}+\mathrm{Pb}+\mathrm{Zn}$ (percent)

$\mathrm{Ag}(\mathrm{ppm})$

EXPLANATION

○ Lookout Mountain

« Corbin

$\Delta$ Big Harbor West

$\diamond$ Nutkwa area

- Khayyam

* Ruby Tuesday

$\star$ Copper City

+ Keete Inlet

Figure 4. Ternary plots of average whole-rock compositions of sulfiderich samples from significant volcanogenic massive sulfide (VMS) deposits in study area (fig. 1). Separate fields for samples from Wales Group deposits (stippled) and Moira Sound unit deposits (hachured) are compiled from data of Barrie (1984), Thurston (1994), Maas and others (1995), Terry and Gibson (1998), Abacus Mining and Exploration Corp. (2003, URL http://www.amemining.com/), and this study (tables 3, 4). A, Cu-PbZn ternary plot. LO, Lookout Mountain (including the Dama deposit); NK, Nutkwa area. Data for two samples of base-metal-poor massive pyrite from the Barrier Islands are omitted. $B,(\mathrm{Cu}+\mathrm{Pb}+\mathrm{Zn})-\mathrm{Au}-\mathrm{Ag}$ ternary plot. Auriferous and base-metal fields for ancient VMS deposits $(n=370)$ from Hannington and others (1999). 
Table 2. Average base- and precious-metal contents in sulfide-rich samples from major volcanogenic massive sulfide deposits on southern Prince of Wales Island, southeastern Alaska.

[Data are compiled only for mineralized samples containing $>3$ weight percent $\mathrm{Cu}+\mathrm{Pb}+\mathrm{Zn}$; data sources: Barrie (1984),

Thurston (1994), Maas and others (1995), Terry and Gibson (1998), and this study]

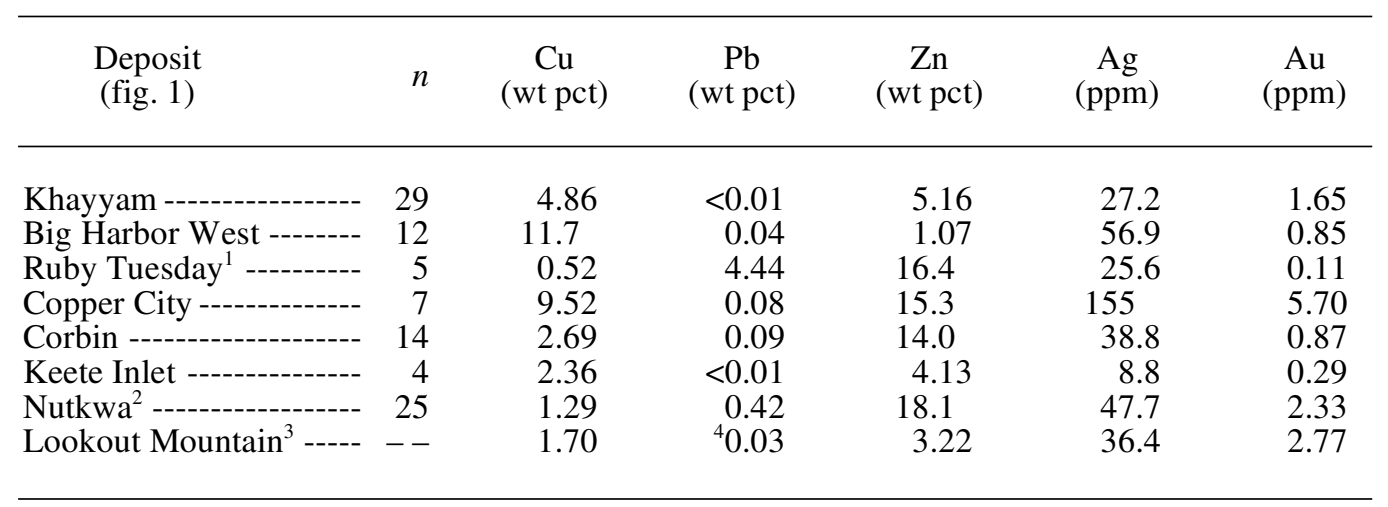

${ }^{1}$ Includes both the Fish Show and Polymetal Lode deposits.

${ }^{2}$ Includes both the Nutkwa Main and Nutkwa North deposits.

${ }^{3}$ Inferred geologic resource from Niblack Mining Corp. (2006, URL http://www.niblackmining.com/).

${ }^{4}$ Estimated from analyses of four U.S. Geological Survey samples.

Group, is compositionally distinct from the other samples (fig. $4 A$ ), probably because of its very low base-metal contents.

Average proportions of base and precious metals in major VMS deposits of the study area (fig. 1), including the fields defined by individual samples from the VMS deposits in the Wales Group and Moira Sound unit, are plotted in figure $4 B$. In contrast to the pattern shown by base metals only (fig. $4 A$ ), figure $4 B$ suggests that the samples from the Moira Sound unit are slightly Ag rich relative to those from the Wales Group. Sulfide-rich samples from the Wales Group generally contain proportionately more $\mathrm{Cu}+\mathrm{Pb}+\mathrm{Zn}$ and less $\mathrm{Ag}$ relative to those from the Moira Sound unit. We do not consider this difference to be an artifact of sampling density because the Ag-poor compositions of samples from the Wales Group are distinct from those of samples from the Moira Sound unit. Au proportions are broadly similar in both sample groups. We note, however, that the Au proportions in individual samples vary considerably, with the maximum values occurring in samples from the Copper City, Lookout Mountain, and Nutkwa deposits (table 2), possibly reflecting isolated gold grains in single samples rather than a homogeneous distribution of Au.

\section{Trace Metals}

Bulk compositions of sulfide-rich rocks vary widely for many metals. Among the trace metals, Co content ranges from $<10$ to $398 \mathrm{ppm}$ and broadly correlates with $\mathrm{Ni}$ content $(<10-253 \mathrm{ppm})$; maximum contents of both $\mathrm{Co}$ and $\mathrm{Ni}$ occur mostly in samples from the Khayyam and Stumble-On deposits (fig. 5A). Samples containing more than 1 weight percent $\mathrm{Cu}$ show an overall positive correlation of $\mathrm{Cu}$ with $\mathrm{Ag}$ contents; maximum $\mathrm{Ag}$ contents were measured in samples from the Copper City and Niblack-Lookout Mountain deposits (fig. $5 B$ ). A positive correlation between $\mathrm{Pb}$ and $\mathrm{Sb}$ in some samples (fig. 5C) suggests the presence of one or more $\mathrm{Pb}-\mathrm{Sb}$ sulfosalt minerals, such as boulangerite $\left(\mathrm{Pb}_{5} \mathrm{Sb}_{4} \mathrm{~S}_{11}\right)$ or bournonite $\left(\mathrm{PbCuSbS}_{3}\right)$, particularly in galena-rich samples from the Ruby Tuesday (Fish Show) deposit. Somewhat high contents of $\mathrm{Sb}(\max 77 \mathrm{ppm})$ and $\mathrm{Ag}(\max 310 \mathrm{ppm})$ may reflect, respectively, Sb-rich pyrite in one sample from the Barrier Islands No. 2 deposit and minor tetrahedrite $\left[(\mathrm{Cu}, \mathrm{Fe}, \mathrm{Ag})_{12}(\mathrm{Sb}\right.$, As) $\left.{ }_{4} \mathrm{~S}_{13}\right]$ in one sample from the Copper City deposit (fig. $5 D$ ). Overall, $\mathrm{Zn}$ and $\mathrm{Hg}$ contents show a positive correlation, with samples from the Khayyam and Stumble-On deposits yielding the maximum $\mathrm{Hg}$ content for a given $\mathrm{Zn}$ content (fig. $5 E$ ). Au and As contents are uncorrelated, even for Au-rich (4.4-9.3 ppm) samples from the Copper City, Khayyam, Lookout Mountain, and Niblack deposits (fig. $5 F$ ).

\section{Sulfide Mineral Chemistry}

LA-ICP-MS analyses of different sulfide minerals show a range of nonessential-element contents that reflects both mineral inclusions and crystallographic substitutions (for example, Huston and others, 1995), where "nonessential elements" are defined as metals and nonmetals that are not required for the formation of a specific sulfide mineral, such as $\mathrm{Cu}$ and $\mathrm{Pb}$ in pyrite and $\mathrm{Sb}$ and $\mathrm{Ag}$ in galena. Mineral inclusions containing nonessential elements are easily observed microscopically in reflected light, although some are too small $(<1 \mu \mathrm{m}$ diam $)$ to be visible even at $500 \times$ magnification. The 
Table 3. Representative whole-rock analyses of sulfide-rich samples from volcanogenic massive sulfide deposits in the Wales Group on southern Prince of Wales Island and vicinity, southeastern Alaska.

[Major-element analyses in weight percent; minor- and trace-element analyses in parts per million. All analyses were performed at XRAL Laboratories in Denver, Colo., by inductively coupled plasma atomic-emission spectrometry, atomic-absorption spectrometry, and fire-assay methods. Total $\mathrm{Fe} a \mathrm{Fe}_{2} \mathrm{O}_{3}$. Elements analyzed for but not measured above their lower limits of detection (in parentheses): Be $(1 \mathrm{ppm}), \mathrm{U}(100 \mathrm{ppm})]$

\begin{tabular}{|c|c|c|c|c|c|c|c|c|c|c|c|c|c|c|c|}
\hline Sample ---- & --1 & 2 & 3 & 4 & 5 & 6 & 7 & 8 & 9 & 10 & 11 & 12 & 13 & 14 & 15 \\
\hline \multicolumn{16}{|c|}{ Major elements } \\
\hline$\overline{\mathrm{Al}_{2} \mathrm{O}_{3}-\cdots--}$ & 0.18 & 0.72 & 0.12 & 0.24 & 0.13 & 6.40 & 5.45 & 3.66 & 0.35 & 0.43 & 0.12 & 1.27 & 2.71 & 5.53 & 8.65 \\
\hline $\mathrm{TiO}_{2}$ & $<0.01$ & 0.04 & 0.01 & $<0.01$ & $<0.01$ & 0.03 & 0.03 & 0.13 & $<0.01$ & $<0.01$ & $<0.1$ & 0.01 & 0.02 & 0.09 & 0.10 \\
\hline $\mathrm{Fe}_{2} \mathrm{O}_{3}$ & 43.6 & 41.3 & 37.2 & 15.2 & 43.9 & 29.0 & 31.0 & 16.0 & 33.6 & 43.8 & 23.0 & 40.0 & 29.0 & 45.5 & 11.6 \\
\hline $\mathrm{MnO}-----$ & 0.006 & 0.012 & 0.002 & 0.029 & 0.005 & 0.137 & 0.284 & 0.019 & 0.063 & 0.016 & 0.023 & 0.556 & 0.025 & 0.008 & 0.007 \\
\hline MgO ----- & 0.09 & 0.36 & 0.06 & 0.22 & 0.09 & 3.83 & 5.78 & 0.02 & 0.08 & 0.42 & 0.09 & 1.28 & 0.58 & 1.25 & 0.72 \\
\hline $\mathrm{CaO}$ & 0.08 & 0.04 & 0.08 & 0.03 & 0.03 & 0.13 & 0.27 & 0.01 & 0.26 & 0.03 & 0.11 & 2.11 & 0.03 & 0.03 & 0.13 \\
\hline $\mathrm{Na}_{2} \mathrm{O}$----- & $<0.01$ & $<0.01$ & 0.01 & 0.01 & $<0.01$ & 0.04 & $<0.01$ & 0.25 & 0.01 & $<0.01$ & $<0.01$ & $<0.01$ & 0.12 & 0.26 & 0.15 \\
\hline $\mathrm{K}_{2} \mathrm{O}$ & $<0.01$ & 0.01 & $<0.01$ & $<0.01$ & 0.01 & 0.06 & 0.11 & 2.41 & $<0.01$ & $<0.01$ & $<0.01$ & $<0.01$ & 0.64 & 1.34 & 2.71 \\
\hline $\mathrm{P}_{2} \mathrm{O}_{5}$ & 0.03 & 0.03 & 0.01 & 0.02 & 0.02 & 0.09 & 0.17 & 0.01 & 0.16 & 0.03 & 0.02 & 0.04 & 0.03 & 0.03 & 0.04 \\
\hline $\mathrm{S}^{2-}$ & 50.4 & 43.6 & 34.7 & 34.3 & 37.0 & 18.9 & 26.6 & 27.1 & 41.2 & 42.1 & 36.9 & 37.4 & 38.0 & 41.8 & 9.04 \\
\hline \multicolumn{16}{|c|}{ Minor and trace elements } \\
\hline Li------- & $<2$ & $<2$ & $<2$ & $<2$ & $<2$ & 20 & 16 & $<2$ & $<2$ & $<2$ & $<2$ & $<2$ & $<2$ & $<2$ & 3 \\
\hline Sr------- & $<2$ & $<2$ & $<2$ & $<2$ & $<2$ & 5 & 3 & 7 & 15 & $<2$ & 109 & 130 & 50 & 7 & 8 \\
\hline Ga -------- & 48 & 40 & 30 & 121 & 48 & 63 & 38 & 25 & 60 & 39 & 76 & 50 & 39 & 39 & 19 \\
\hline V --------- & 74 & 86 & 27 & 67 & 85 & 96 & 19 & 16 & 24 & 34 & 15 & 158 & 44 & 90 & 39 \\
\hline Sc-------- & $<2$ & $<2$ & 2 & $<2$ & $<2$ & $<2$ & $<2$ & 3 & $<2$ & $<2$ & $<2$ & $<2$ & $<2$ & 4 & 4 \\
\hline Co------ & 78 & 146 & 19 & 45 & 112 & 39 & 16 & 4 & 19 & 157 & 40 & 24 & 19 & 182 & 61 \\
\hline Ni-------- & 14 & 16 & 11 & 4 & 42 & 8 & 7 & 14 & 15 & 15 & 7 & 12 & 12 & 37 & 5 \\
\hline Mo ------- & 26 & 56 & 8 & 14 & 26 & 20 & 8 & 111 & 46 & 46 & 27 & 24 & 45 & 18 & 39 \\
\hline $\mathrm{Cu}$------- 1 & 3,910 & 63,850 & 342,000 & 386 & 18,950 & 45,160 & 233,700 & 700 & 69,780 & 107,800 & 588 & 13,830 & 3,270 & 298 & 15,210 \\
\hline $\mathrm{Pb}$--------- & 19 & 41 & 50 & 12 & & 37 & 620 & 63,440 & 205 & 205 & 5,600 & 69 & 4,630 & 30 & 16 \\
\hline $\mathrm{Zn}$------- 3 & 0,530 & 113,100 & 19,140 & 566,700 & 124,100 & 490 & 2,840 & 248,300 & 251,200 & 2,420 & 426,100 & 71,340 & 297,500 & 804 & 238 \\
\hline Cd-------- & 72 & 269 & 80 & 2,160 & 422 & $<2$ & 13 & 806 & 763 & 4 & 1,600 & 173 & 909 & $<2$ & $<2$ \\
\hline Bi--------- & $<50$ & $<50$ & $<50$ & $<50$ & $<50$ & $<50$ & $<50$ & $<50$ & $<50$ & $<50$ & 95 & $<50$ & $<50$ & $<50$ & $<50$ \\
\hline Ag------- & 9 & 35 & 136 & 4 & 22 & 17 & 97 & 62 & 127 & 70 & 81 & 7 & 19 & $<2$ & 31 \\
\hline Au------- & 0.60 & 1.65 & 1.37 & 0.09 & 0.10 & 1.08 & 1.49 & 0.15 & 5.38 & 1.48 & 0.30 & 0.41 & 0.09 & $<0.01$ & 0.17 \\
\hline Sb -------- & $<0.60$ & $<0.60$ & $<0.60$ & 0.70 & $<0.60$ & 2.00 & 1.00 & 56.2 & 10.8 & 11.0 & 3.80 & $<0.60$ & 4.30 & $<0.60$ & $<0.60$ \\
\hline As -------- & 64.1 & 59.0 & 6.50 & 4.70 & 37.9 & 41.8 & 11.8 & 250 & 21.2 & 591 & 11.0 & 12.2 & 6.30 & 5.70 & 12.0 \\
\hline Se-------- & 11.5 & 39.3 & $<0.20$ & 1.50 & 4.50 & 4.60 & 3.50 & 13.3 & 0.20 & 168 & 6.30 & 1.70 & 1.10 & 16.4 & 15.3 \\
\hline Te -------- & 2.30 & 53.8 & $<0.10$ & 0.40 & 2.30 & 8.10 & 0.40 & 5.90 & 5.70 & 37.7 & 36.3 & 1.00 & 0.10 & 6.70 & 5.80 \\
\hline Hg-------- & 0.38 & 1.14 & 0.40 & 8.71 & 1.94 & 0.14 & 0.56 & 8.46 & 15.9 & 1.2 & 31.3 & 1.17 & 14.0 & 0.08 & 0.14 \\
\hline Tl-------- & $<0.1$ & $<0.1$ & $<0.1$ & $<0.1$ & $<0.1$ & $<0.1$ & $<0.1$ & 0.2 & $<0.1$ & 2.1 & $<0.1$ & 0.2 & 0.6 & $<0.1$ & 0.2 \\
\hline
\end{tabular}

Samples:

1. JS-00-33H, upper Khayyam Mine dump; granoblastic pyritic sulfide with minor matrix chalcopyrite and sphalerite.

2. JS-00-62E, lower Khayyam Mine dump; granoblastic pyritic sulfide with abundant matrix sphalerite and chalcopyrite.

3. JS-00-62F, lower Khayyam Mine dump; massive fine-grained chalcopyrite with sparse sphalerite and quartz.

4. JS-00-36C, Stumble-On Mine dump; granoblastic sphalerite with minor pyrite.

5. JS-00-36D, Stumble-On Mine dump; massive fine-grained pyrrhotite with sphalerite and minor pyrite.

6. JS-00-29C, Big Harbor East Mine adit; semimassive pyritic sulfide in quartz-chlorite schist with abundant chalcopyrite.

7. JS-00-31D, Big Harbor West Mine outcrop; semimassive chalcopyrite in chlorite schist with minor pyrite and sparse sphalerite.

8. RT-FS-MS, Ruby Tuesday (Fish Show) Mine dump; semimassive sphalerite in felsic tuff with abundant galena and sparse chalcopyrite.

9. JS-00-55C, Copper City Mine dump; massive fine-grained chalcopyrite with abundant pyrite and minor chalcopyrite and quartz.

10. JS-00-56D, Corbin Mine dump; massive fine-grained pyritic sulfide with abundant chalcopyrite and trace sphalerite.

11. JS-00-56J, Corbin Mine dump; layered massive sphalerite and pyrite with sparse quartz and trace galena.

12. JS-00-53D, Keete Inlet Mine dump; massive pyritic sulfide with minor chalcopyrite, sphalerite, quartz, magnetite, and carbonate.

13. JS-00-39A, Nutkwa Mine dump; massive pyritic sulfide with abundant sphalerite, minor quartz, chlorite, and sericite, and sparse chalcopyrite and galena

14. JS-00-42A, Trocadero Bay "exhalite" outcrop; coarse-grained pyritic sulfide with minor quartz, sericite, and chlorite and trace chalcopyrite and sphalerite.

15. JS-00-66, Deer Bay "exhalite" outcrop; quartz-sericite-chlorite schist with disseminated pyrite and sparse chalcopyrite. 
Table 4. Representative whole-rock analyses of sulfide-rich samples from volcanogenic massive sulfide deposits in the Moira Sound unit on southern Prince of Wales Island and vicinity, southeastern Alaska.

[Major-element analyses in weight percent; minor- and trace-element analyses in parts per million. All analyses were performed at XRAL Laboratories in Denver, Colo., by inductively coupled plasma atomic-emission spectrometry, atomic-absorption spectrometry, and fire-assay methods. Total $\mathrm{Fe}_{\mathrm{as}} \mathrm{Fe}_{2} \mathrm{O}_{3}$. Elements analyzed for but not measured above their lower limits of detection (in parentheses): Be (1 ppm), $\mathrm{U}$ (100 ppm)]

\begin{tabular}{|c|c|c|c|c|c|c|c|c|c|c|c|c|c|c|c|}
\hline Sample -- & --- & 2 & 3 & 4 & 5 & 6 & 7 & 8 & 9 & 10 & 11 & 12 & 13 & 14 & 15 \\
\hline \multicolumn{16}{|c|}{ Major elements } \\
\hline $\mathrm{Al}_{2} \mathrm{O}_{3}$ & 0.48 & 4.77 & 4.79 & 0.23 & 0.29 & 2.11 & 5.88 & 1.87 & 3.53 & 5.87 & 1.33 & 14.3 & 3.14 & 0.93 & 6.38 \\
\hline $\mathrm{TiO}_{2}$ & $<0.008$ & 0.045 & 0.008 & $<0.008$ & $<0.008$ & $<0.008$ & 0.008 & 0.018 & 0.017 & 0.025 & 0.13 & 0.42 & 0.08 & 0.04 & 0.04 \\
\hline $\mathrm{Fe}_{2} \mathrm{O}_{3}$ & 44.3 & 26.9 & 39.9 & 46.2 & 40.3 & 34.0 & 39.5 & 43.5 & 40.5 & 35.6 & 47.8 & 30.3 & 47.3 & 51.9 & 37.3 \\
\hline $\mathrm{MnO}$ & 0.019 & 0.002 & 0.065 & 0.048 & 0.011 & 0.080 & 0.081 & 0.004 & 0.052 & 0.003 & 0.006 & 0.032 & 0.094 & 18.40 & 0.048 \\
\hline MgO ----- & 0.35 & 0.26 & 3.56 & 0.29 & 0.24 & 1.28 & 4.91 & 0.14 & 2.29 & 0.11 & 0.64 & 0.99 & 2.38 & 0.81 & 3.73 \\
\hline $\mathrm{CaO}$ & 0.04 & 0.02 & 0.27 & 1.10 & 0.20 & 1.99 & 0.04 & 0.03 & 0.01 & 0.01 & 0.14 & 0.22 & 0.03 & 0.52 & 0.07 \\
\hline $\mathrm{Na}_{2} \mathrm{O}$----- & 0.01 & 0.03 & 0.01 & 0.02 & $<0.01$ & $<0.01$ & $<0.01$ & 0.61 & 0.09 & 0.20 & 0.03 & 0.27 & 0.02 & $<0.01$ & 0.11 \\
\hline $\mathrm{K}_{2} \mathrm{O}$ & $<0.01$ & 1.64 & $<0.01$ & $<0.01$ & $<0.01$ & $<0.01$ & $<0.01$ & 0.25 & 0.13 & 1.63 & 0.19 & 4.06 & 0.17 & 0.01 & 0.92 \\
\hline $\mathrm{P}_{2} \mathrm{O}_{5}$ & 0.02 & 0.02 & 0.19 & 0.11 & 0.03 & 0.01 & 0.03 & 0.02 & 0.01 & $<0.01$ & 0.01 & 0.01 & 0.01 & 0.06 & 0.04 \\
\hline $\mathrm{S}^{2}--------$ & 41.9 & 23.8 & 34.5 & 18.1 & 45.5 & 32.1 & 33.7 & 44.2 & 29.9 & 26.4 & 37.5 & 23.0 & 35.2 & 23.3 & 33.0 \\
\hline \multicolumn{16}{|c|}{ Minor and trace elements } \\
\hline Li--------- & $<2$ & $<2$ & 7 & $<2$ & $<2$ & $<2$ & 8 & $<2$ & 12 & $<2$ & 9 & 10 & 5 & 3 & 11 \\
\hline Sr-------- & $<2$ & 4 & 4 & 16 & 3 & 22 & $<2$ & 10 & 5 & 17 & 4 & 17 & $<2$ & 8 & 9 \\
\hline Ga-------- & 40 & 24 & 41 & 124 & 65 & 37 & 40 & 40 & 6 & 13 & $<4$ & 13 & 8 & $<4$ & 32 \\
\hline V -------- & 33 & 16 & 31 & 74 & 39 & 77 & 68 & 34 & 12 & 13 & 26 & 260 & 54 & 22 & 26 \\
\hline Sc--------- & $<2$ & 2 & 2 & $<2$ & $<2$ & 4 & 3 & $<2$ & $<2$ & 6 & $<2$ & 37 & 2 & $<2$ & $<2$ \\
\hline Co -------- & 26 & 12 & 29 & 19 & 23 & 19 & 26 & 23 & 55 & 22 & 55 & 28 & 102 & 11 & 37 \\
\hline Ni-------- & 24 & 6 & 12 & 13 & 10 & 8 & 15 & 13 & $<3$ & $<3$ & 253 & 47 & $<3$ & 4 & 15 \\
\hline Мo ------- & 16 & 40 & 105 & 36 & 44 & 104 & 88 & 9 & 146 & 16 & 58 & 13 & 13 & 6 & 12 \\
\hline $\mathrm{Cu}$-------- & 31,540 & 16,200 & 42,530 & 31,990 & 57,010 & 290,700 & 17,130 & 4,310 & 1,100 & 11,310 & 45 & 71 & 12 & 63 & 207 \\
\hline $\mathrm{Pb}$------- & 146 & 19 & 32 & 4220 & 29 & 35 & 20 & 423 & 12 & 10 & 25 & 1,230 & 22 & 42 & 10 \\
\hline Zn -------- & 9,870 & 152 & 8,660 & 65,750 & 134,400 & 1,740 & 15,930 & 785 & 496 & 30 & 56 & 153 & 143 & 6,390 & 898 \\
\hline Cd -------- & 51 & $<2$ & 18 & 170 & 493 & 10 & 62 & $<2$ & 3 & $<2$ & $<2$ & $<2$ & $<2$ & 55 & $<2$ \\
\hline Bi--------- & $<50$ & $<50$ & 51 & $<50$ & $<50$ & $<50$ & $<50$ & $<50$ & $<50$ & $<50$ & $<50$ & $<50$ & $<50$ & $<50$ & $<50$ \\
\hline Ag------- & 78 & 8 & 42 & 116 & 62 & 150 & 47 & 112 & 4 & 29 & $<2$ & 30 & $<2$ & 4 & $<2$ \\
\hline Au-------- & 4.62 & 0.53 & 1.09 & 11.0 & 0.66 & 0.30 & 0.34 & 4.39 & 0.76 & 2.15 & 0.03 & 0.47 & 0.03 & 0.01 & $<0.01$ \\
\hline Sb ------- & 5.80 & 0.80 & 1.00 & 1.80 & $<0.60$ & $<0.60$ & $<0.60$ & 0.90 & $<0.60$ & 0.80 & 23 & 77 & $<0.60$ & 5.50 & $<0.60$ \\
\hline As -------- & 257 & 23.7 & 85.5 & 94.2 & 14.5 & 3.90 & 41.9 & 8.80 & 7.10 & 2.90 & 248 & 1,820 & 6.40 & 92.9 & 62.3 \\
\hline Se-------- & 3.90 & 2.10 & 19.0 & 0.40 & 1.10 & 0.40 & 4.70 & 5.20 & 19.5 & 4.00 & 3.40 & $<0.20$ & 8.80 & 3.00 & 24.5 \\
\hline Te -------- & 29.7 & 9.60 & 66.2 & 50.0 & 22.2 & $<0.10$ & 18.5 & 59.6 & 9.00 & 49.6 & $<0.10$ & 0.10 & 5.80 & 2.20 & 7.80 \\
\hline Hg ------- & 2.81 & 0.07 & 1.12 & 9.11 & 4.39 & 0.26 & 0.53 & 0.14 & 0.40 & 0.84 & 0.07 & 1.53 & 0.09 & 0.09 & 0.05 \\
\hline Tl--------- & 0.3 & 0.2 & $<0.1$ & $<0.1$ & $<0.1$ & $<0.1$ & 0.1 & 0.2 & $<0.1$ & 0.2 & 0.6 & 72 & 0.3 & $<0.1$ & 0.2 \\
\hline
\end{tabular}

Sampıes: 1 . JS-00-28A, lower Niblack Mine dump; weakly layered massive pyritic sulfide with minor chalcopyrite and sparse sphalerite.

2. JS-00-28C, lower Niblack Mine dump; siliceous rocks with abundant disseminated pyrite, lesser chalcopyrite, and minor sericite.

3. JS-00-28I, upper Niblack Mine dump; semimassive pyrite and chalcopyrite in quartz-bearing chlorite schist.

4. 84AGK053C, upper Niblack Mine dump; massive magnetite iron-formation with abundant pyrite and chalcopyrite and angular clasts of jasper.

5. LO-53/624.2, Dama Prospect drill core, Niblack area; layered pyrite, sphalerite, and minor chalcopyrite.

6. LO-61/573.0, Dama Prospect drill core, Niblack area; massive fine-grained chalcopyrite with minor pyrite and sparse sphalerite.

7. LO-61/577.5, Dama Prospect drill core, Niblack area; semimassive pyritic sulfide in chloritic tuff(?) with sparse chalcopyrite and sphalerite.

8. LO-99/367, Lookout Mountain Prospect drill core, Niblack area; massive pyritic sulfide with minor quartz and sericite and trace chalcopyrite and sphalerite.

9. MC-MS-2, Moira Copper Mine dump; semimassive pyritic sulfide with abundant quartz, minor chlorite, and trace chalcopyrite.

10. MC-MS2, Moira Copper Mine dump; semimassive pyritic sulfide with minor quartz, chlorite, and sericite and sparse chalcopyrite.

11. BI1-MS, Barrier Islands Prospect No. 1; brecciated massive fine-grained pyrite with sparse quartz and chlorite.

12. BI2-MS, Barrier Islands Prospect No. 2; semimassive pyritic sulfide with abundant sericite and sparse quartz.

13. BI7-MS, Barrier Islands Prospect No. 7; semimassive pyritic sulfide with minor quartz and chlorite.

14. BI9-MS-1, Nichols Bay Mine dump; massive fine-grained pyrrhotite (partially oxidized) with abundant disseminated Mn-rich garnet, minor pyrite, and sparse sphalerite.

15. JS-00-57A, Datzkoo Harbor occurrence, southeastern Dall Island; massive pyritic sulfide with minor quartz and chlorite and trace sphalerite. 

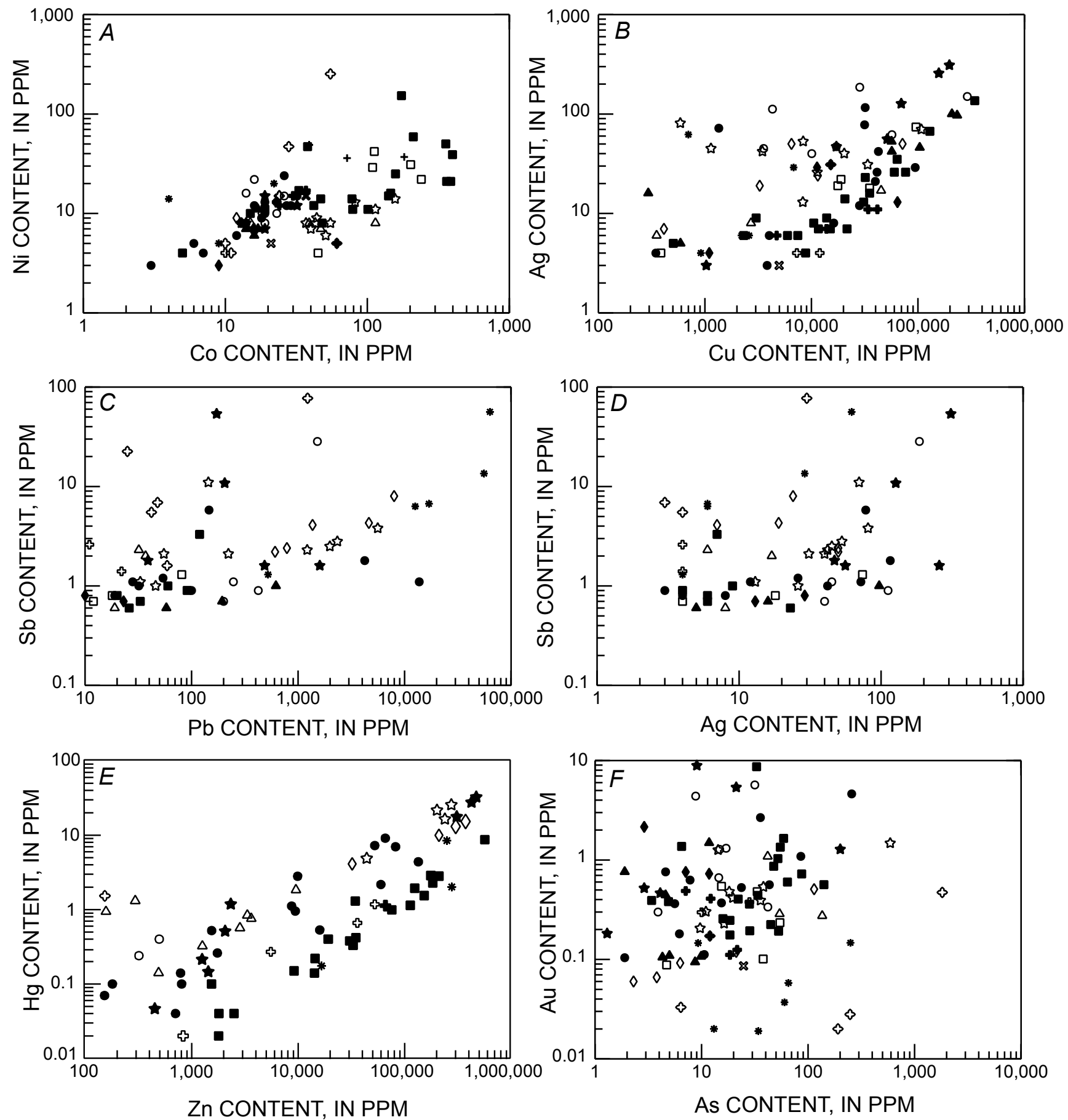

EXPLANATION
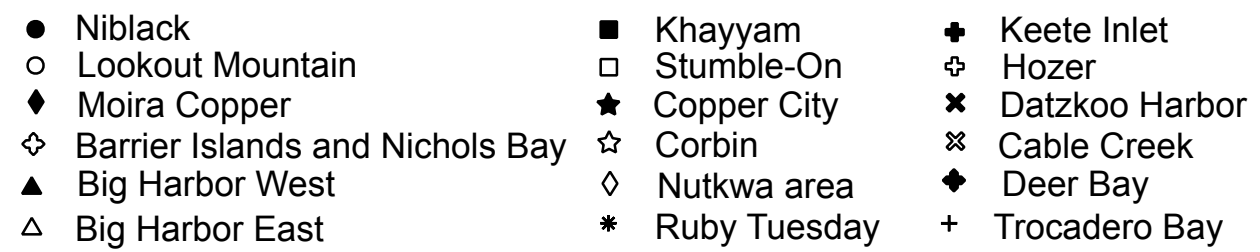

Figure 5. Binary plots of whole-rock compositions of sulfide-rich samples from study area (fig. 1). $A$, Co versus Ni contents. $B$, Cu versus $\mathrm{Ag}$ contents. $C$, Pb versus Sb contents. $D, A g$ versus Sb contents. $E, \mathrm{Zn}$ versus $\mathrm{Hg}$ contents. $F$, As versus Au contents. Lookout Mountain includes the Dama deposit. 
very high nonessential-element contents determined from some LA-ICP-MS spectra of apparently inclusion free spots probably record the presence of mineral inclusions on the surface of the sample that were too small to be easily visible, or were intersected by the laser beam during penetration as much as 10 $\mu \mathrm{m}$ below the surface. In our study, very large spectral peaks for nonessential elements (for example, $\mathrm{Bi}$ in pyrite, $\mathrm{Sn}$ in chalcopyrite) were screened during data reduction of the LA-ICP-MS analyses, such that the high contents of these elements were excluded from the calculated compositions. In some samples, such as those from the Big Harbor and Copper City deposits, meaningful analyses of sphalerite were unobtainable, owing to myriad small inclusions of chalcopyrite and (or) pyrite.

\section{Pyrite}

High nonessential-element contents in pyrite are dominated by $\mathrm{Cu}, \mathrm{Zn}$, and $\mathrm{Pb}$ contents that correlate with inclusions of chalcopyrite, sphalerite, and galena, respectively. Absolute abundances of these elements are unknown but estimated to range from several thousand parts per million to as much as several weight percent. Excluding base metals and trace elements that are unlikely to substitute for Fe within the pyrite lattice, the largest LA-ICP-MS spectral peaks are dominated by Mo, which likely reflects inclusions of molybdenite, although possible stoichiometric substitution of Mo for Fe cannot be ruled out (see Huston and others, 1995). High Mo contents were measured in pyrite grains from the VMS deposits in both the Wales Group (Corbin, Keete Inlet, Nutkwa Main) and the Moira Sound unit (Copper City, Dama). Some pyrite grains from the Corbin deposit also have high $\mathrm{Bi}$, As, and $\mathrm{Sb}$ contents in the same analytical spots, suggesting residence in one or more sulfosalt minerals. Very high Bi contents unaccompanied by high $\mathrm{Cu}, \mathrm{Zn}, \mathrm{Pb}$, As, or Sb contents in several pyrite grains from the Lookout Mountain and Niblack deposits may reflect the presence of native bismuth, which occurs in massive sulfide deposits elsewhere (for example, Craig, 1980; Callaghan, 2001). The high Sn content in some pyrite samples from the Moira Copper deposit suggests a host in either cassiterite or stannite. Detailed microbeam studies involving scanning electron microscopy and electron-microprobe analysis will be required to identify the mineralogic residence of these high metal contents.

Analyses of inclusion-free spots in pyrite $(n=170)$ indicate mostly low contents of such elements as $\mathrm{Co}, \mathrm{Ni}, \mathrm{Mn}, \mathrm{Tl}$, $\mathrm{As}, \mathrm{Sb}$, and $\mathrm{Se}$ (figs. $6 A, 6 B$; tables 5,6 ), any of which may replace $\mathrm{Fe}(\mathrm{Co}, \mathrm{Ni}, \mathrm{Mn}, \mathrm{Tl})$ or $\mathrm{S}(\mathrm{As}, \mathrm{Sb}, \mathrm{Se})$ within the pyrite lattice by either stoichiometric or nonstoichiometric substitution (Huston and others, 1995). With few exceptions, maximum contents are 200 ppm As, 30 ppm Sb, 200 ppm Co, 150 ppm Ni, 100 ppm Mn, 200 ppm Se, and 1 ppm Tl. As contents are relatively high in some pyrite samples from the Big Harbor East deposit ( $\max 1,848 \mathrm{ppm}$ ) and the Ruby Tuesday (Fish Show) deposit (max 3,050 ppm), suggesting the presence of an $\mathrm{Fe}(\mathrm{As}, \mathrm{S})_{2}$ solid solution, as discussed for pyrite samples from other VMS deposits by Huston and others (1995). Pyrite samples from the Khayyam and Stumble-On deposits are Co rich (max 1,436 and 2,057 ppm, respectively). Pyrite samples from the Barrier Islands deposits are distinctive in their extremely high contents of several trace elements, including maximum contents of 1.44 weight percent As, 283 ppm Sb, 3,552 ppm Mn, and 274 ppm Tl (figs. 6A, 6B; table 6). Pyrite from the Barrier Islands No. 2 deposit has the highest contents of these elements among the three localities sampled. Overall, pyrite samples from the Barrier Islands VMS deposits are chemically unlike those from other VMS deposits in the study area (fig. 1), suggesting different conditions of formation or preservation. The very high $\mathrm{As}, \mathrm{Sb}, \mathrm{Mn}$, and $\mathrm{Tl}$ contents in pyrite samples from the Barrier Islands deposits do not require separate mineralogic residence but, instead, probably reflect substitution by these elements within the pyrite lattice (see Huston and others, 1995).

\section{Pyrrhotite}

Six analyses of inclusion-free pyrrhotite in a sample of massive coarse-grained pyrrhotite-pyrite-chalcopyrite ore from the Stumble-On Mine generally indicate low contents $(<30$ ppm) of a broad suite of trace elements (table 5), except for maximum contents of $86.6 \mathrm{ppm} \mathrm{Ni}$ and 1,147 ppm Se, which were measured in different analytical spots. Ni can substitute for Fe within the pyrrhotite lattice; however, it is unclear whether the high Se content reflects crystallographic substitution (that is, of Se for $\mathrm{S}$ ) or the presence of a small Se-rich mineral inclusion.

\section{Sphalerite}

In hand specimens, sphalerite in the VMS deposits of the study area (fig. 1) varies widely in color, ranging from yellow at the Niblack area and Nutkwa deposits to black at the Khayyam and Stumble-On deposits. Sphalerite in all of these deposits is unzoned, as observed in polished and doubly polished thin sections. Some deposits (for example, Corbin, Khayyam, Ruby Tuesday) contain sphalerite with abundant small chalcopyrite inclusions. Galena inclusions are also common in sphalerite grains from the Corbin, Dama, Lookout Mountain, and Ruby Tuesday (Fish Show) deposits. During data reduction, large spectral peaks for $\mathrm{Hg}$ were identified in some sphalerite grains from the Khayyam deposit, and large peaks for In were measured in some sphalerite grains from the Dama and Nutkwa Main deposits, but because the size of these peaks implied contamination by inclusions (for example In in chalcopyrite), elemental contents were not determined.

Analyses of inclusion-free spots in sphalerite $(n=35)$ show the presence of various trace elements (tables 7,8 ) with generally dispersed patterns (figs. $6 C-6 F$ ). These elements substitute for either $\mathrm{Zn}$ or $\mathrm{S}$ within the sphalerite lattice (for example, Huston and others, 1995). Overall, Fe contents range from 330 ppm in the Nutkwa Main deposit to 7.46 weight percent in the Khayyam deposit. Mn contents are relatively 

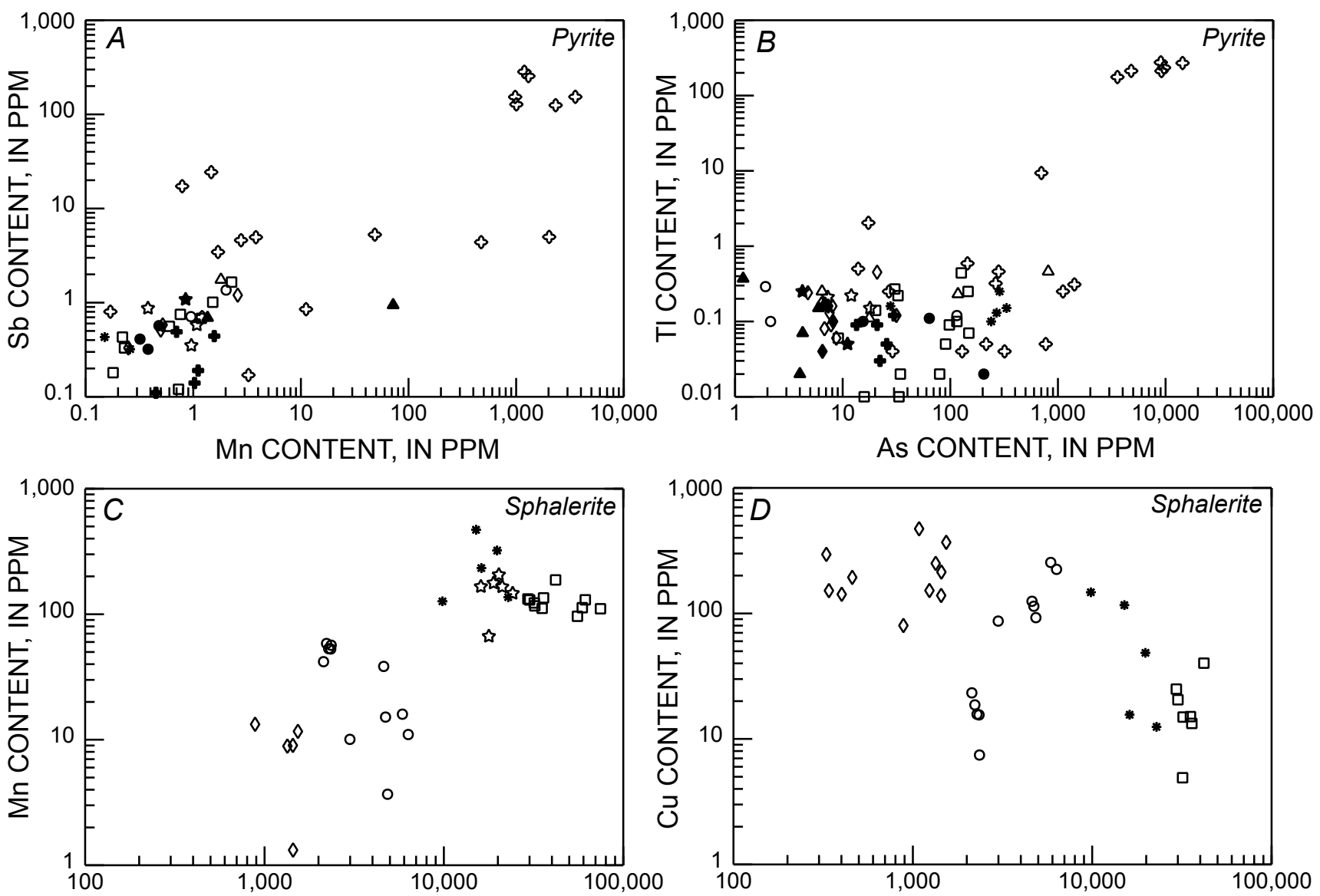

Fe CONTENT, IN PPM

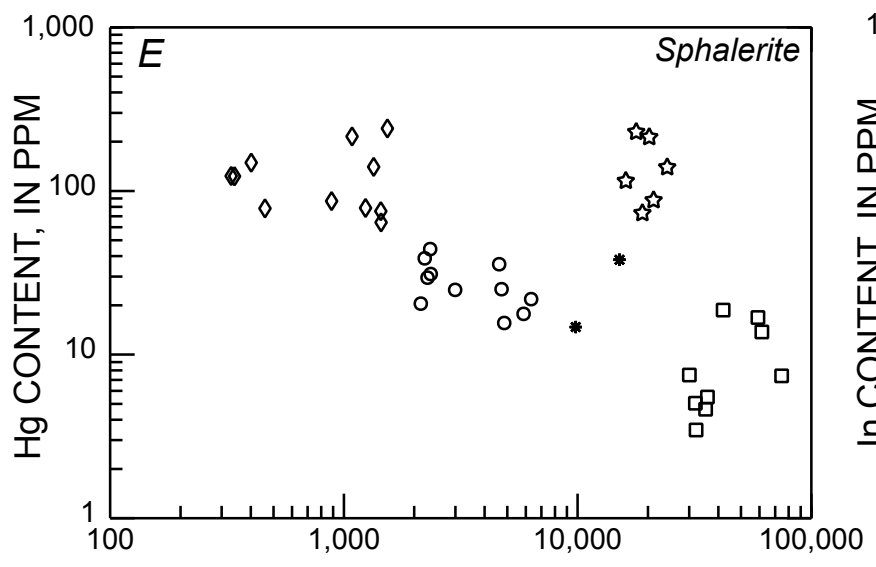

Fe CONTENT, IN PPM

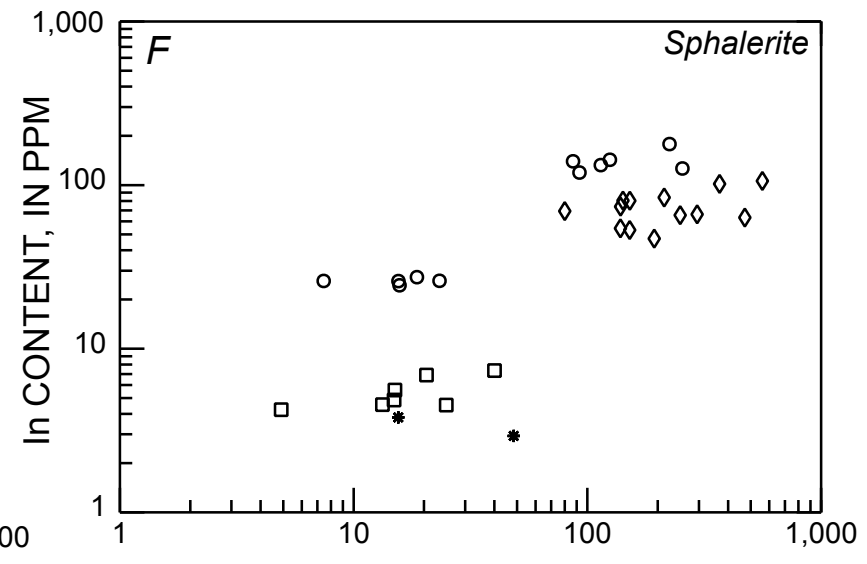

Cu CONTENT, IN PPM

\section{EXPLANATION}

- Niblack

- Lookout Mountain

- Moira Copper

\& Barrier Islands and Nichols Bay
- Big Harbor West
¿ Corbin
$\triangle$ Big Harbor East
+ Keete Inlet
Khayyam and Stumble-On
$\diamond \quad$ Nutkwa area
$\star$ Copper City

Figure 6. Binary plots of laser-ablation inductively coupled plasma mass-spectrometric analyses of sulfide-rich samples from study area (fig. 1). $A, \mathrm{Mn}$ versus Sb contents in pyrite. $B$, As versus Tl contents in pyrite. $C$, Fe versus Mn contents in sphalerite. $D$, Fe versus $C$ u contents in sphalerite. $E$, Fe versus $\mathrm{Hg}$ contents in sphalerite. $F$, Cu versus In contents in sphalerite. Lookout Mountain includes the Dama deposit. 
[Laser-ablation inductively coupled plasma mass-spectrometric analyses at the USGS laboratory in Denver, Colo. N.r., not reported. Minerals: po, pyrrhotite; py, pyrite. All samples contain minor to major amounts of quartz, and some also contain a minor amount of sericite. Fe content not reported]

\begin{tabular}{|c|c|c|c|c|c|c|c|c|c|c|c|c|c|c|c|}
\hline Sample ----- & 1 & 2 & 3 & 4 & 5 & 6 & 7 & 8 & 9 & 10 & 11 & 12 & 13 & 14 & 15 \\
\hline Mineral----- & py & py & py & py & py & py & py & py & py & py & py & py & py & po & po \\
\hline Mn --------- & 2.90 & 2.02 & $<0.01$ & 3,550 & $<0.01$ & $<0.01$ & $<0.01$ & 0.29 & $<0.01$ & 0.85 & 0.38 & 1.03 & $<0.01$ & 4.08 & $<0.01$ \\
\hline Cu ----------- & 1.52 & 8.66 & 8.57 & 56.4 & 9.64 & n.r. & 4.01 & 2.90 & $<0.01$ & n.r. & n.r. & 1.58 & 3.65 & n.r. & n.r. \\
\hline Pb ----------- & 0.02 & 0.27 & $<0.01$ & 3.23 & $<0.01$ & $<0.01$ & 0.07 & 3.20 & 0.31 & $<0.01$ & $<0.01$ & 0.22 & $<0.01$ & $<0.01$ & $<0.01$ \\
\hline Zn ----------- & 3.22 & $<0.01$ & 18.1 & 58.7 & $<0.01$ & 12.5 & 5.40 & 7.66 & 0.85 & 8.30 & 8.61 & 6.29 & 18.3 & 21.9 & $<0.01$ \\
\hline Sn ----------- & $<0.01$ & $<0.01$ & $<0.01$ & 1.25 & 3.87 & 1.01 & 1.49 & 2.30 & 0.44 & 1.59 & 2.77 & $<0.01$ & $<0.01$ & 12.8 & 1.90 \\
\hline Co---------- & 1.25 & 152 & 8.34 & 62.1 & 698 & 3.46 & 2,060 & 104 & 9.37 & 0.96 & 37.7 & 96.5 & 1.67 & $<0.01$ & 2.75 \\
\hline Ni----------- & 12.4 & 4,600 & 131 & 32.3 & 6.65 & 271 & 1.22 & 55.4 & 79.4 & 35.0 & 22.2 & 29.5 & 5.00 & 6.37 & 25.2 \\
\hline Mo --------- & 1.10 & 3.18 & $<0.01$ & 2.40 & $<0.01$ & 2.16 & 0.15 & $<0.01$ & 0.78 & $<0.01$ & 0.42 & 1.25 & $<0.01$ & $<0.01$ & $<0.01$ \\
\hline In ----------- & 0.05 & $<0.01$ & $<0.01$ & 0.12 & $<0.01$ & $<0.01$ & $<0.01$ & 0.74 & 0.11 & 0.10 & 0.13 & 0.14 & $<0.01$ & 0.36 & $<0.01$ \\
\hline Cd ---------- & 2.60 & $<0.01$ & 1.42 & $<0.01$ & $<0.01$ & $<0.01$ & $<0.01$ & 3.82 & 3.91 & 0.51 & $<0.01$ & 0.68 & 2.07 & 6.94 & 29.4 \\
\hline Bi------------ & $<0.01$ & $<0.01$ & 0.02 & $<0.01$ & $<0.01$ & $<0.01$ & $<0.01$ & 0.15 & $<0.01$ & 0.01 & $<0.01$ & $<0.01$ & $<0.01$ & $<0.01$ & $<0.01$ \\
\hline Ag--------- & $<0.01$ & 2.29 & 2.01 & 4.67 & $<0.01$ & $<0.01$ & 1.02 & $<0.01$ & $<0.01$ & 0.09 & 0.62 & 2.02 & 0.69 & 22.9 & 3.31 \\
\hline Sb ----------- & $<0.01$ & 1.36 & $<0.01$ & 154 & 0.31 & 1.01 & $<0.01$ & $<0.01$ & 0.91 & 1.08 & 0.87 & 0.14 & 0.94 & $<0.01$ & $<0.01$ \\
\hline As ---------- & 28.1 & 1.92 & 8.16 & 4,800 & 127 & $<0.01$ & 64.7 & 813 & 360 & 28.8 & 30.1 & 9.68 & 1.42 & 5.94 & 9.40 \\
\hline Se------------ & 42.3 & 24.0 & 40.4 & $<0.01$ & 38.9 & $<0.01$ & $<0.01$ & $<0.01$ & $<0.01$ & $<0.01$ & 8.81 & 24.2 & $<0.01$ & $<0.01$ & 1,150 \\
\hline Te --------- & $<0.01$ & $<0.01$ & 1.50 & $<0.01$ & 5.47 & 6.89 & $<0.01$ & $<0.01$ & $<0.01$ & 0.58 & 1.89 & 0.62 & 1.34 & $<0.01$ & 3.40 \\
\hline Hg ---------- & $<0.01$ & 0.51 & $<0.01$ & 3.61 & $<0.01$ & 0.31 & 0.09 & 0.33 & $<0.01$ & 0.64 & 0.50 & $<0.01$ & $<0.01$ & 3.21 & 11.0 \\
\hline Tl------------ & $<0.01$ & 0.29 & 0.10 & 212 & 0.44 & $<0.01$ & $<0.01$ & 0.46 & $<0.01$ & $<0.01$ & $<0.01$ & $<0.01$ & $<0.01$ & 1.33 & $<0.01$ \\
\hline
\end{tabular}

Samples:

1. JS-00-28A, lower Niblack Mine dump; pyrite with minor sphalerite and chalcopyrite.

2. LO-99/290, Lookout Mountain Prospect drill core; pyrite with minor chalcopyrite and sphalerite in fine-grained rhyolite.

3. MC-MS, Moira Copper Mine dump; pyrite and chalcopyrite.

4. BI-2-MS, Barrier Islands occurrence No. 2 (Gehrels and others, 1983); pyrite with trace sphalerite.

5, 6. JS-00-62E, upper Khayyam Mine dump; pyrite with sphalerite and chalcopyrite.

7. JS-00-36C, Stumble-On Mine dump; pyrite porphyroblasts in massive granular sphalerite.

8. JS-00-29C, Big Harbor East Mine adit; pyrite with abundant chalcopyrite.

9. RT-FS-MS2, Ruby Tuesday (Fish Show) Mine dump; pyrite with sphalerite, galena, and minor chalcopyrite

10. JS-00-55C, Copper City Mine dump; pyrite with abundant chalcopyrite, minor magnetite, and trace sphalerite.

11. JS-00-56I, Corbin Mine dump; pyrite with abundant sphalerite.

12. JS-00-53D, Keete Inlet Mine dump; pyrite with abundant chalcopyrite and minor sphalerite.

13. JS-00-39A, Nutkwa Main Mine dump; pyrite with abundant sphalerite, minor chalcopyrite, and trace galena.

14, 15. JS-00-36D, Stumble-On Mine dump; pyrrhotite with abundant pyrite and sphalerite and minor chalcopyrite. 
Table 6. Average composition and ranges in composition of pyrite in sulfide-rich samples from southern Prince of Wales Island and vicinity, southeastern Alaska.

[Minor- and trace-element analyses in parts per million by laser-ablation inductively coupled plasma mass spectrometry at the USGS laboratory in Denver, Colo. the Standard deviation (s.d.) is $1 \sigma$ value. Grouping of deposits (see table 1) is based on stratigraphic, structural, and metamorphic parameters. Wales Group deposits comprise two samples each from the Khayyam, Ruby Tuesday (Fish Show), and Stumble-On deposits and one sample each from the Big Harbor East, Big Harbor West, Copper City, Corbin, Keete Inlet, Nutkwa Main, and Nutkwa North deposits]

\begin{tabular}{|c|c|c|c|c|c|c|c|c|c|}
\hline \multirow{3}{*}{$n$ n----------- } & \multicolumn{3}{|c|}{ Wales Group deposits } & \multicolumn{3}{|c|}{ Moira Sound unit deposits } & \multicolumn{3}{|c|}{ Barrier Islands deposits } \\
\hline & & 113 & & & 27 & & & 30 & \\
\hline & Mean & S.d. & Range & Mean & S.d. & Range & Mean & S.d. & Range \\
\hline Mn -------- & 1.53 & 7.75 & $0.0-72.0$ & 0.44 & 0.76 & $0.0-2.90$ & 445 & 864 & $0.0-3,552$ \\
\hline Co--------- & 203 & 366 & $0.0-2,057$ & 21.6 & 31.8 & $0.0-152$ & 46.0 & 77.8 & $0.0-315$ \\
\hline Ni --------- & 34.5 & 71.2 & $0.0-468$ & 288 & 968 & $0.42-4,593$ & 132 & 220 & $0.0-874$ \\
\hline $\mathrm{Cu}$--------- & 5.72 & 7.68 & $0.0-47.5$ & 7.77 & 7.97 & $0.58-31.1$ & 28.5 & 44.7 & $0.0-191$ \\
\hline In----------- & 0.11 & 0.18 & $0.0-0.97$ & 0.16 & 0.33 & $0.0-1.32$ & 0.11 & 0.14 & $0.0-0.44$ \\
\hline Zn---------- & 11.2 & 29.3 & $0.0-290$ & 8.99 & 12.6 & $0.0-55.1$ & 34.6 & 76.5 & $0.0-380$ \\
\hline Cd--------- & 1.07 & 1.67 & $0.0-7.58$ & 0.95 & 1.47 & $0.0-5.71$ & 1.11 & 1.73 & $0.0-6.36$ \\
\hline $\mathrm{Pb}$---------- & 0.18 & 0.36 & $0.0-3.20$ & 0.18 & 0.22 & $0.0-0.84$ & 1.24 & 1.81 & $0.0-8.41$ \\
\hline Ag -------- & 0.77 & 1.11 & $0.0-5.93$ & 2.53 & 5.01 & $0.0-18.3$ & 2.67 & 4.81 & $0.0-19.1$ \\
\hline As --------- & 124 & 382 & $0.0-3,050$ & 20.8 & 44.1 & $0.0-204$ & 1,979 & 3,679 & $0.0-14,412$ \\
\hline $\mathrm{Sb}---------$ & 0.39 & 0.62 & $0.0-4.03$ & 0.38 & 0.50 & $0.0-2.12$ & 39.2 & 78.6 & $0.0-283$ \\
\hline Bi --------- & 0.02 & 0.05 & $0.0-0.32$ & 0.06 & 0.12 & $0.0-0.54$ & 0.02 & 0.02 & $0.0-0.10$ \\
\hline Hg -------- & 0.67 & 1.08 & $0.0-8.79$ & 0.34 & 0.52 & $0.0-1.85$ & 2.21 & 3.79 & $0.0-14.9$ \\
\hline Tl --------- & 0.08 & 0.14 & $0.0-0.69$ & 0.09 & 0.14 & $0.0-0.65$ & 46.4 & 94.5 & $0.0-275$ \\
\hline Se --------- & 48.0 & 143 & $0.0-1,134$ & 34.1 & 50.7 & $0.0-204$ & 45.8 & 66.0 & $0.0-224$ \\
\hline Te---------- & 1.20 & 2.98 & $0.0-27.3$ & 0.48 & 0.65 & $0.0-2.38$ & 0.68 & 1.37 & $0.0-7.23$ \\
\hline Mo --------- & 2.90 & 21.1 & $0.0-225$ & 88.8 & 420 & $0.0-2,186$ & 12.4 & 46.3 & $0.0-251$ \\
\hline Sn --------- & 0.73 & 0.94 & $0.0-4.79$ & 0.42 & 0.62 & $0.0-2.23$ & 0.96 & 1.29 & $0.0-6.30$ \\
\hline
\end{tabular}

high (100-500 ppm) only in spots containing $>1$ weight percent $\mathrm{Fe}$. An opposite trend is apparent for $\mathrm{Cu}$, with maximum $\mathrm{Cu}$ contents $(>100 \mathrm{ppm})$ measured in the most $\mathrm{Fe}$ poor $(<0.2$ weight percent) spots. Results for $\mathrm{Hg}$ are clustered mainly by deposit, with minimum $\mathrm{Hg}$ contents $(<10 \mathrm{ppm})$ measured in Fe-rich ( $>3$ weight percent) spots in sphalerite samples from the Khayyam deposit but maximum $\mathrm{Hg}$ contents ( $>100$ ppm) measured in sphalerite samples from the Nutkwa Main and Corbin deposits. Significantly, the lowest $\mathrm{Hg} / \mathrm{Fe}$ ratios in sphalerite were determined in samples from the Khayyam and Stumble-On deposits, which are the most highly metamorphosed, to upper amphibolite grade.

\section{Chalcopyrite}

Inclusions of native bismuth in chalcopyrite are inferred by the very high spectral peaks measured for $\mathrm{Bi}$ in some samples from the Moira Copper and Niblack deposits. These peaks lack associated $\mathrm{As}, \mathrm{Sb}, \mathrm{Pb}$, or $\mathrm{Ag}$ peaks and so apparently do not reflect residence in a Bi-rich sulfosalt mineral. Native bismuth is considered the likely host, although microbeam techniques, such as scanning electron microscopy, would be required to confirm this hypothesis. Chalcopyrite from the Moira Copper deposit also has a very high Sn content but not a low $\mathrm{Cu}$ or $\mathrm{S}$ content, suggesting the presence of stannite or a similar Sn-rich sulfosalt mineral.

Analyses of inclusion-free spots in chalcopyrite $(n=40)$ show relatively low contents $(<100 \mathrm{ppm})$ of most of the trace elements analyzed (tables 7, 9). However, samples from the Khayyam deposit, in particular, are metal rich, including maximum contents of $252 \mathrm{ppm} \mathrm{Ni}, 437 \mathrm{ppm} \mathrm{Zn,} \mathrm{2,400} \mathrm{ppm} \mathrm{Se,} \mathrm{and}$ $153 \mathrm{ppm} \mathrm{Cd}$. High Zn contents also were measured in some chalcopyrite grains from other VMS deposits in the study area, with maximum contents of $625 \mathrm{ppm} \mathrm{Zn}$ in a sample from the Corbin deposit, $200 \mathrm{ppm}$ As in a sample from the Dama deposit, 1,830 ppm Se in a sample from the Copper City deposit, and $213 \mathrm{ppm}$ In in a sample from the Moira Copper deposit. The high $\mathrm{Zn}$ and $\mathrm{Cd}$ contents may reflect submicroscopic sphalerite inclusions, whereas the high $\mathrm{Ni}, \mathrm{Se}, \mathrm{As}$, and In contents probably reflect substitution by these elements within the chalcopyrite lattice: $\mathrm{Ni}$ and $\mathrm{In}$ for $\mathrm{Cu}$ or $\mathrm{Fe}$, and Se and As for S (see Huston and others, 1995; Axelsson and Rodushkin, 2001).

\section{Galena}

Galena is abundant only in the Ruby Tuesday deposit but also occurs in other deposits as small grains or inclusions in sulfides. Visible inclusions are generally absent in galena from VMS deposits of the study area (fig. 1). However, very high spectral peaks for some elements suggest the presence of submicroscopic inclusions in the galena. For example, galena from the Ruby Tuesday (Fish Show) deposit locally has high $\mathrm{Sb}$ and $\mathrm{Ag}$ contents that together imply residence in a sulfosalt mineral, such as tetrahedrite. One sample from the Dama deposit contained galena grains in sphalerite with high $\mathrm{Ag}$ 
Table 7. Representative minor- and trace-element analyses of sphalerite, chalcopyrite, and galena in sulfide-rich samples from southern Prince of Wales Island and vicinity, southeastern Alaska.

[Minor- and trace-element analyses in parts per million by laser-ablation inductively coupled plasma mass spectrometry at the USGS laboratory in Denver, Colo. N.r., not reported. Minerals: cp, chalcopyrite; gl, galena; sl, sphalerite. All samples contain minor to major amounts of quartz, and some also contain a minor amount of sericite]

\begin{tabular}{|c|c|c|c|c|c|c|c|c|c|c|c|c|c|c|c|}
\hline $\begin{array}{l}\text { Sample ----- } \\
\text { Mineral---- }\end{array}$ & $\begin{array}{c}1 \\
\mathrm{sl}\end{array}$ & $\begin{array}{c}2 \\
\mathrm{sl}\end{array}$ & $\begin{array}{r}3 \\
\text { sl } \\
\end{array}$ & $\begin{array}{c}4 \\
\text { sl }\end{array}$ & $\begin{array}{r}5 \\
\text { sl }\end{array}$ & $\begin{array}{l}6 \\
\text { sl }\end{array}$ & $\begin{array}{c}7 \\
\text { sl }\end{array}$ & $\begin{array}{c}8 \\
\mathrm{sl}\end{array}$ & $\begin{array}{r}9 \\
\mathrm{cp}\end{array}$ & $\begin{array}{l}10 \\
\mathrm{cp}\end{array}$ & $\begin{array}{l}11 \\
\mathrm{cp}\end{array}$ & $\begin{array}{l}12 \\
\mathrm{cp}\end{array}$ & $\begin{array}{l}13 \\
\mathrm{cp}\end{array}$ & $\begin{array}{c}14 \\
\mathrm{gl}\end{array}$ & $\begin{array}{l}15 \\
\mathrm{gl}\end{array}$ \\
\hline Fe----------- & 2,990 & 4,620 & 2,280 & 59,100 & 32,100 & 9,830 & 17,800 & 1,540 & N.r. & N.r. & N.r. & N.r. & N.r. & $<0.01$ & $<0.01$ \\
\hline Mn --------- & 10.1 & 38.4 & 53.2 & 113 & 117 & 127 & 66.6 & 11.6 & 0.50 & $<0.01$ & 6.73 & $<0.01$ & 2.35 & $<0.01$ & $<0.01$ \\
\hline Cu ---------- & 86.8 & 125 & 15.7 & N.r. & 14.9 & 147 & N.r. & 368 & N.r. & N.r. & N.r. & N.r. & N.r. & 15.1 & $<0.01$ \\
\hline Pb --------- & 6.27 & 1.68 & 0.37 & $<0.01$ & $<0.01$ & 7.56 & $<0.01$ & 11.6 & 0.44 & $<0.01$ & $<0.01$ & 0.67 & $<0.01$ & N.r. & N.r. \\
\hline Zn ---------- & N.r. & N.r. & N.r. & N.r. & N.r. & N.r. & N.r. & N.r. & 81.3 & $<0.01$ & 119 & 133 & 5.96 & 7.54 & $<0.01$ \\
\hline Sn ---------- & 3.49 & 14.9 & 4.10 & 6.93 & 2.23 & 10.8 & $<0.01$ & 46.5 & $<0.01$ & 10.3 & 1.55 & 2.44 & 19.8 & 1.81 & 2.25 \\
\hline Co------- & 7.97 & $<0.01$ & 12.9 & 0.64 & 6.04 & $<0.01$ & $<0.01$ & $<0.01$ & $<0.01$ & 0.79 & 4.57 & $<0.01$ & 2.14 & $<0.01$ & $<0.01$ \\
\hline Ni----------- & $<0.01$ & 17.6 & 0.74 & $<0.01$ & $<0.01$ & $<0.01$ & $<0.01$ & 7.23 & $<0.017$ & 17.0 & 1.64 & $<0.01$ & 12.6 & $<0.01$ & $<0.01$ \\
\hline Mo --------- & $<0.01$ & $<0.01$ & 0.44 & 33.9 & 1.08 & 28.3 & 42.9 & 22.1 & 80.8 & 3.45 & $<0.01$ & $<0.01$ & 5.69 & 3.81 & 0.33 \\
\hline In ----------- & 140 & 143 & 24.4 & 12.2 & 4.85 & $<0.01$ & 33.8 & 102 & 64.6 & 213 & 2.56 & 18.1 & 50.5 & 0.14 & $<0.01$ \\
\hline Cd---------- & 2,480 & 2,220 & 1,670 & 1,090 & 1,480 & 898 & 1,520 & 1,760 & $<0.01$ & 10.7 & 6.08 & 16.9 & $<0.01$ & 17.3 & 9.66 \\
\hline Bi------------ & 3.73 & 0.65 & 0.01 & $<0.01$ & $<0.01$ & 0.66 & $<0.01$ & 0.26 & $<0.01$ & 0.23 & 0.12 & 0.18 & 0.12 & 5.94 & 0.02 \\
\hline Ag--------- & 87.5 & $<0.01$ & 5.77 & $<0.01$ & 0.36 & $<0.01$ & 10.0 & 2.50 & 29.1 & $<0.01$ & 17.2 & 5.41 & 16.6 & 453 & 126 \\
\hline Sb -------- & $<0.01$ & 4.23 & $<0.01$ & $<0.01$ & $<0.01$ & $<0.01$ & 38.2 & $<0.01$ & 13.7 & $<0.01$ & $<0.01$ & 3.99 & $<0.01$ & 164 & 81.4 \\
\hline As -------- & 8.52 & $<0.01$ & 4.62 & $<0.01$ & 1.32 & 95.2 & 54.0 & 20.5 & $<0.01$ & $<0.01$ & $<0.01$ & 32.1 & 14.0 & $<0.01$ & 5.23 \\
\hline Se---------- & $<0.01$ & 196 & 102 & 1,040 & 99.1 & 661 & 1,043 & $<0.01$ & 1,370 & $<0.01$ & 646 & $<0.01$ & 1,830 & 247 & 27.3 \\
\hline Te ------ & $<0.01$ & 34.8 & $<0.01$ & 4.22 & 0.06 & 5.70 & 15.5 & $<0.01$ & 21.3 & 13.1 & 3.41 & $<0.01$ & 3.74 & $<0.01$ & 3.98 \\
\hline Hg ---------- & 24.9 & 35.7 & 29.5 & 16.8 & 3.46 & 14.7 & 229 & 241 & $<0.01$ & $<0.01$ & 5.33 & 3.75 & 10.8 & 1.31 & 0.37 \\
\hline Tl------------ & 0.50 & $<0.01$ & 0.52 & 0.43 & $<0.01$ & $<0.01$ & 8.94 & 0.43 & 6.28 & 1.49 & 2.66 & $<0.01$ & $<0.01$ & 2.59 & 1.06 \\
\hline
\end{tabular}

\section{Samples:}

1, 2. LO-53/624.2, Dana Prospect drill core, Niblack area; sphalerite with pyrite and chalcopyrite.

3. LO-99/290, Lookout Mountain Prospect drill core, Niblack area; sphalerite with pyrite and minor chalcopyrite.

4. JS-00-62E, lower Khayyam Mine dump (tram terminal); sphalerite with pyrite and chalcopyrite.

5. JS-00-36C, Stumble-On Mine dump; sphalerite with porphyroblastic pyrite.

6. RT-FS-MS2, Ruby Tuesday (Fish Show) Mine dump; sphalerite with pyrite, galena, and minor chalcopyrite.

7. JS-00-56I, Corbin Mine dump; sphalerite with abundant pyrite.

8. JS-00-39A, Nutkwa Main Prospect dump; sphalerite with pyrite, minor chalcopyrite, and trace galena.

9. LO-53/624.2, Dama Prospect drill core, Niblack area; chalcopyrite with pyrite and minor sphalerite.

10. MC-MS, Moira Copper Mine dump; chalcopyrite with pyrite and trace sphalerite.

11. JS-00-62E, lower Khayyam Mine dump (tram terminal); chalcopyrite with pyrite and minor sphalerite.

12. JS-00-31D, Big Harbor West Mine outcrop; chalcopyrite with pyrite and trace sphalerite.

13. JS-00-55C, Copper City Mine dump; chalcopyrite with pyrite, minor magnetite, and trace sphalerite.

14. JS-00-39A, Nutkwa Main Prospect dump; galena with pyrite and minor sphalerite and chalcopyrite.

15. RT-FS-MS2, Ruby Tuesday (Fish Show) Mine dump; galena with sphalerite, pyrite, and minor chalcopyrite. 
Table 8. Average composition and ranges in composition of sphalerite in sulfide-rich samples from southern Prince of Wales Island and vicinity, southeastern Alaska.

[Minor- and trace-element analyses in parts per million by laser-ablation inductively coupled plasma mass spectrometry at the USGS laboratory in Denver, Colo. Standard deviation (s.d.) is 1 value. Grouping of deposits (see table 1) is based on stratigraphic, structural, and metamorphic parameters. Wales Group deposits comprise one sample each from the Corbin, Khayyam, Nutkwa Main, Nutkwa North, Ruby Tuesday (Fish Show), and Stumble-On deposits; Moira Sound unit deposits comprise two samples from the Lookout Mountain Prospect]

\begin{tabular}{|c|c|c|c|c|c|c|}
\hline \multirow{3}{*}{$n-------$} & \multicolumn{3}{|c|}{ Wales Group deposits } & \multicolumn{3}{|c|}{ Moira Sound unit deposits } \\
\hline & \multicolumn{3}{|c|}{28} & \multicolumn{3}{|c|}{7} \\
\hline & Mean & S.d. & Range & Mean & S.d. & Range \\
\hline Fe---------- & 2.43 & 2.03 & $0.03-7.46$ & 0.30 & 0.12 & $0.21-0.49$ \\
\hline Mn -------- & 121 & 102 & $0.0-470$ & 40.2 & 22.0 & $3.68-58.4$ \\
\hline Co ------- & 4.56 & 6.67 & $0.0-25.4$ & 9.70 & 7.95 & $0.0-22.4$ \\
\hline $\mathrm{Ni}$---------- & 8.44 & 25.4 & $0.0-121$ & 6.85 & 5.37 & $0.74-17.7$ \\
\hline $\mathrm{Cu}$--------- & 83.5 & 127 & $0.0-472$ & 41.0 & 43.3 & $7.44-114$ \\
\hline In ---------- & 29.2 & 30.4 & $0.0-102$ & 54.5 & 49.0 & $24.4-133$ \\
\hline Cd --------- & 1,465 & 336 & $898-2,354$ & 1,928 & 344 & $1,616-2,556$ \\
\hline $\mathrm{Pb}--------$ & 1.21 & 2.65 & $0.0-11.6$ & 1.45 & 1.31 & $0.37-4.16$ \\
\hline Ag --------- & 12.7 & 19.9 & $0.0-74.3$ & 17.7 & 14.3 & $4.00-44.2$ \\
\hline As ------- & 25.9 & 42.9 & $0.0-156$ & 15.0 & 18.0 & $0.0-46.7$ \\
\hline $\mathrm{Sb}-------$ & 3.43 & 8.28 & $0.0-38.2$ & 0.65 & 1.44 & $0.0-3.87$ \\
\hline Bi ---------- & 0.09 & 0.17 & $0.0-0.66$ & 0.65 & 1.43 & $0.0-3.87$ \\
\hline Hg -------- & 71.5 & 80.3 & $0.0-241$ & 29.2 & 9.96 & $15.6-44.2$ \\
\hline Tl ---------- & 0.87 & 1.92 & $0.0-8.94$ & 0.18 & 0.23 & $0.0-0.52$ \\
\hline Se---------- & 311 & 424 & $0.0-1,233$ & 14.6 & 38.6 & $0.0-102$ \\
\hline Te --------- & 3.97 & 8.12 & $0.0-32.8$ & 1.49 & 1.97 & $0.0-5.13$ \\
\hline Mo -------- & 15.4 & 30.5 & $0.0-134$ & 5.68 & 14.3 & $0.0-38.1$ \\
\hline Sn -------- & 11.3 & 14.8 & $0.0-53.8$ & 5.93 & 6.42 & $0.0-19.0$ \\
\hline
\end{tabular}

and $\mathrm{Bi}$ contents, consistent with the presence of other types of sulfosalt inclusion. One galena grain from the Ruby Tuesday (Fish Show) deposit also had a very high Sn content (estimated at $>1$ weight percent) without a concomitant decrease in $\mathrm{S}$ content, implying the presence of stannite or a similar Sn-rich sulfosalt mineral.

Limited data for inclusion-free spots in galena $(n=7)$ show uniformly low contents ( $<20 \mathrm{ppm}$, table 7$)$ of most of the trace elements analyzed, except in galena from the Nutkwa Main deposit, which has maximum contents of $164 \mathrm{ppm} \mathrm{Sb}$, $247 \mathrm{ppm} \mathrm{Se}$, and $609 \mathrm{ppm} \mathrm{Ag}$. High contents of these elements were also measured in galena from the Ruby Tuesday (Fish Show) deposit, with maximum contents of $97.3 \mathrm{ppm} \mathrm{Sb}$, $949 \mathrm{ppm} \mathrm{Se}$, and $132 \mathrm{ppm} \mathrm{Ag}$. These trace elements probably are hosted mainly within the galena lattice, although the high Ag content could reflect residence in one or more sulfosalt minerals (see Watling and others, 1995).

\section{Sulfur Isotopes}

Sulfur-isotopic analyses were performed to determine the sulfur sources of the VMS deposits of the study area (fig. 1) and to assess mineralizing processes. Sulfur-isotopic values of sulfides in the deposits (fig. 7; table 10) mainly range from
-3 to 17 permil, excluding one very low value of -31.1 permil for semimassive pyrite from the Barrier Islands No. 1 deposit. The highest $\delta^{34} \mathrm{~S}_{\text {sulfide }}$ values were measured in samples from the Big Harbor East and West deposits. Two groups of samples form isotopic outliers: one with $\delta^{34} \mathrm{~S}$ values near 0 permil for sulfides in magnetite iron-formation from the Niblack deposit, and the other with a $\delta^{34} S$ value of $\sim 3$ permil for semimassive pyrite from the Barrier Islands deposits. Massive pyrrhotite and pyrite in separate samples from the Nichols Bay deposit have $\delta^{34} \mathrm{~S}$ values of -2.8 and -0.8 permil, respectively. Minor barite in a Mn-rich exhalite associated with the Big Harbor West deposit has a $\delta^{34} \mathrm{~S}$ value of 30.6 permil; a similar $\delta^{34} \mathrm{~S}$ value of 30.4 permil was measured on a pretectonic barite lens in limestone from the Lime Point deposit.

The $\delta^{34} \mathrm{~S}$ values for sulfide minerals in the VMS deposits in the Moira Sound unit (fig. 8) range from -2.8 to 10.4 permil (avg 6.1 \pm 4.0 permil; $n=22$ ), overlapping some of those for sulfide minerals in the VMS deposits in the Wales Group, which range from 5.9 to 17.4 permil (avg $11.5 \pm 2.7$ permil; $n=67$ ). In comparison, modern sea-floor hydrothermal systems with a significant sedimentary component in their footwall sequences have $\delta^{34} S_{\text {sulfide }}$ values averaging -5 to 8 permil, with an overall range of 10 to 15 permil (Shanks, 2001). Sulfur-isotopic values for sulfides in Phanerozoic VMS deposits elsewhere show a comparable spread, with $\delta^{34} \mathrm{~S}_{\text {sulfide }}$ values averaging 5 to 10 permil over a similar range (Ohmoto, 1986). Thus, the VMS depos- 
Table 9. Average composition and ranges in composition of chalcopyrite in sulfide-rich samples from southern Prince of Wales Island and vicinity, southeastern Alaska.

[Minor- and trace-element analyses in parts per million by laser-ablation inductively coupled plasma mass spectrometry at the USGS laboratory in Denver, Colo. Standard deviation (s.d.) is $1 \sigma$ value. Grouping of deposits (see table 1) is based on stratigraphic, structural, and metamorphic parameters. Wales Group deposits comprise one sample each from the Big Harbor East, Big Harbor West, Copper City, Corbin, Keete Inlet, Khayyam, Nutkwa Main, and Ruby Tuesday (Fish Show) deposits; Moira Sound unit deposits comprise three samples from the Lookout Mountain Prospect and one sample from the Moira Copper Prospect]

\begin{tabular}{|c|c|c|c|c|c|c|}
\hline \multirow{3}{*}{$n-\cdots--$} & \multicolumn{3}{|c|}{ Wales Group deposits } & \multicolumn{3}{|c|}{ Moira Sound unit deposits } \\
\hline & & 30 & & & 10 & \\
\hline & Mean & S.d. & Range & Mean & S.d. & Range \\
\hline Zn------- & 88.3 & 133 & $0.0-625$ & 70.1 & 49.0 & $0.0-143$ \\
\hline Mn------ & 5.82 & 15.9 & $0.0-88.1$ & 0.66 & 1.05 & $0.0-3.19$ \\
\hline Co ----- & 1.34 & 2.13 & $0.0-9.60$ & 0.56 & 1.04 & $0.0-3.34$ \\
\hline Ni ------- & 12.4 & 45.8 & $0.0-252$ & 6.81 & 6.63 & $0.0-17.0$ \\
\hline In ------ & 21.3 & 21.2 & $0.0-84.6$ & 42.8 & 63.3 & $6.46-213$ \\
\hline Cd ------ & 9.86 & 27.8 & $0.0-153$ & 8.79 & 9.65 & $0.0-27.4$ \\
\hline $\mathrm{Pb}-------$ & 0.65 & 0.97 & $0.0-3.67$ & 0.37 & 0.42 & $0.0-1.19$ \\
\hline Ag ------ & 14.9 & 18.2 & $0.0-94.5$ & 9.23 & 12.9 & $0.0-30.0$ \\
\hline As------- & 10.7 & 19.2 & $0.0-76.1$ & 46.8 & 73.3 & $0.0-200$ \\
\hline $\mathrm{Sb}-------$ & 2.11 & 3.09 & $0.0-10.1$ & 3.30 & 4.64 & $0.0-13.7$ \\
\hline Bi ------- & 0.13 & 0.21 & $0.0-0.84$ & 0.46 & 0.53 & $0.0-1.45$ \\
\hline Hg ----- & 2.16 & 3.30 & $0.0-11.5$ & 1.28 & 1.34 & $0.0-3.36$ \\
\hline Tl ------- & 0.49 & 0.72 & $0.0-2.66$ & 1.44 & 1.94 & $0.0-6.28$ \\
\hline Se------ & 239 & 563 & $0.0-2,400$ & 258 & 465 & $0.0-1,374$ \\
\hline Te------- & 2.61 & 4.82 & $0.0-21.0$ & 8.17 & 8.57 & $0.0-21.3$ \\
\hline Mo------ & 3.36 & 4.79 & $0.0-15.5$ & 13.3 & 25.1 & $0.0-80.8$ \\
\hline Sn------ & 16.9 & 17.8 & $0.0-68.3$ & 4.48 & 5.44 & $0.0-16.3$ \\
\hline
\end{tabular}

its on Prince of Wales Island and vicinity (fig. 1) display fairly typical $\delta^{34} S$ values for these types of massive sulfide deposit.

Wherever possible, individual sulfide minerals were separated and analyzed for their $\delta^{34} \mathrm{~S}$ value to identify potential mineral-mineral fractionations that might be used for sulfur-isotope geothermometry and for calculating primary or metamorphic temperatures. In table $10, \delta^{34} \mathrm{~S}$ data for sulfide minerals are listed in the expected order of fractionation, from isotopically heaviest to lightest: pyrite $>$ sphalerite pyrrhotite $>$ chalcopyrite $>$ galena. Analysis of these data indicates that most of the sulfide minerals lack significant fractionation, and so sulfur-isotope geothermometry would not be meaningful. The fractionations may be within analytical error because of hightemperature metamorphism. We conclude that the $\delta^{34} S$ values for individual sulfide minerals in the VMS deposits partially to completely reequilibrated during metamorphism, but that the distinct ranges obtained for different samples reflect original, premetamorphic whole-rock values.

Sulfur-isotopic values of bulk sulfide in country rocks of the study area (fig. 1; table 11) were measured to determine whether the sulfur sources of the hydrothermal systems that formed the VMS deposits could be delineated. The wide variation in $\delta^{34} \mathrm{~S}$ values (-10.2 to 19.7 permil) makes source fingerprinting difficult. These $\delta^{34} \mathrm{~S}$ values show some differences that broadly correlate with host lithology (fig. 8) but not with host-rock age. In general, metavolcanic rocks contain sulfides with the highest $\delta^{34} \mathrm{~S}$ values (1.1 to 19.7 permil), followed by carbonates ( -3.7 to 11.3 permil) and siliciclastic metasedimen- tary rocks (-10.2 to 3.2 permil). Probably most of the siliciclastic rocks, many of which are graphitic, and some of the metacarbonate rocks were affected during diagenesis by bacterial sulfate reduction (BSR) that produced negative sulfur-isotopic values (for example, Machel, 2001). The large negative $\delta^{34} S$ value ( -31.1 permil) for pyrite from the Barrier Islands No. 1 deposit probably records extensive BSR, which likely produced the framboidal texture in some of this pyrite. In the metavolcanic rocks (fig. 8), however, no evidence exists for BSR or the introduction of isotopically light sulfur. Instead, the relatively high $\delta^{34} \mathrm{~S}_{\text {sulfide }}$ values of these rocks, far above the typical range for primary sulfide in unaltered volcanic rocks (-1 to 3 permil; Shanks, 2001), probably reflect minor amounts of hydrothermally introduced seawater sulfate that was reduced to sulfide by thermochemical sulfate reduction (TSR). Most likely, these $\delta^{34} \mathrm{~S}$ values represent samples from the low-temperature fringes of sea-floor hydrothermal systems that were only mildly affected by VMS-forming processes.

Additional insight can be gained by comparing the $\delta^{34} S_{\text {sulfide }}$ values of the hydrothermal deposits with those of contemporaneous seawater sulfate (fig. 9). On the basis of the ages of the host rocks, 500-600 m.y. for the Wales Group and 430-480 m.y. for the Moira Sound unit, and the temporal seawater sulfate curve established by analyzing marine evaporates (Claypool and others, 1980; Ross and others, 1995), we conclude that the higher $\delta^{34} S_{\text {sulfide }}$ values obtained for the VMS deposits in the Wales Group reflect higher $\delta^{34} \mathrm{~S}_{\text {sulfate }}$ values in contemporaneous seawater sulfate. Studies of modern sea-floor massive sulfide deposits (Shanks and others, 1995; Shanks, 2001), together with experimental (Shanks and others, 1981; Seyfried and Shanks, 2004) and theoretical (Janecky and Shanks, 1988) studies of sulfide formation, provide a general framework for understanding sea-floor hydrothermal mineralization. These studies have shown that sulfides in VMS deposits, which have long been known to contain volcanic and seawater sulfur components, form as follows. Seawater sulfate is mostly screened from the circulating hydrothermal system by precipitation of anhydrite and $\mathrm{Mg}$ hydroxysulfate at temperatures above $150^{\circ} \mathrm{C}$, and the fraction of seawater sulfate that enters the high-temperature hydrothermal system is quantitatively reduced to sulfide. Simultaneously, the seawater-derived hydrothermal fluids leach and dissolve igneous sulfide from footwall rocks, which is mixed with the reduced seawater sulfate to produce $\delta^{34} \mathrm{~S}_{\text {sulfide }}$ values intermediate between those of igneous rocks $(\sim 0$ permil $)$ and contemporaneous seawater sulfate. Although this process can cause a large variation in $\delta^{34} \mathrm{~S}_{\text {sulfide }}$ value, in practice the systems tend to be self-regulating. Sulfate reduction is accomplished by iron-bearing minerals and the $\mathrm{H}_{2}$ they produce during hydrothermal reactions, and in modern systems that have been studied to date, $\sim 10-40$ percent of the sulfide derives from reduced seawater sulfate that is added to the mix without apparent sulfur-isotope fractionation.

The sulfur-isotopic data for VMS deposits of the study area (fig. 1) provide strong evidence for formation at or near the sea floor by processes much like those in modern subma- 
rine hydrothermal systems. The Wales Group deposits have somewhat higher $\delta^{34} \mathrm{~S}$ values because they formed during a period when seawater sulfate had a $\delta^{34} \mathrm{~S}$ value near 30 permil, whereas the Moira Sound unit deposits formed during a period when seawater sulfate had a $\delta^{34} S$ value of $\sim 25$ permil. Major sulfur sources of the deposits were igneous sulfide and reduced seawater sulfate. The $\delta^{34} \mathrm{~S}$ values of disseminated barite in a Mn-rich exhalite from the Big Harbor West deposit (30.6 permil) and in massive barite from the Lime Point deposit (30.4 permil), both of which are in rocks of the Wales Group, support these conclusions, possibly reflecting the sulfur-isotopic composition of contemporaneous seawater sulfate during Late Proterozoic through Cambrian time.

\section{Discussion}

\section{Primary Textural and Geochemical Signatures}

Whole-rock and mineral compositions of VMS deposits in deformed and metamorphosed sequences reflect various processes, including primary sea-floor mineralization, hydrothermal zone refining in the subsurface, and recrystallization and new-mineral growth during postore deformation and metamorphism (for example, Lydon, 1988; Hannington and others, 1995). In general, sea-floor mineralization in chimney

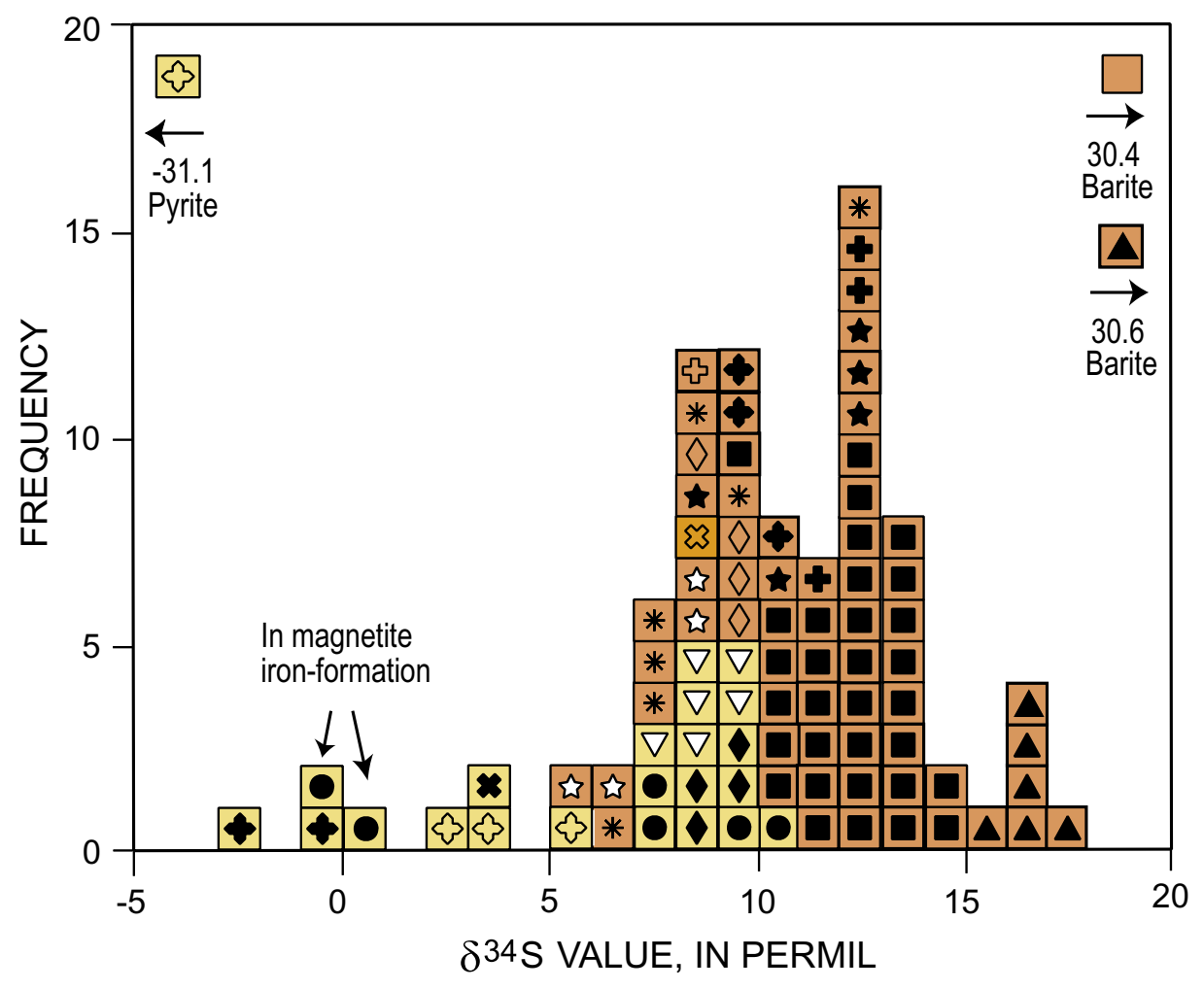

EXPLANATION

\begin{tabular}{|c|c|c|}
\hline Moira Sound unit & \multicolumn{2}{|c|}{ Wales Group } \\
\hline Niblack & $\square$ Khayyam and Stumble-On & $\nabla$ Nutkwa area deposits \\
\hline Barrier Islands & Copper City & $\Delta$ Big Harbor deposits \\
\hline Moira Copper & Corbin & * Ruby Tuesday \\
\hline$\nabla$ Lookout Mountain & $\$$ Keete Inlet & Cable Creek roadcut \\
\hline (జ) Datzkoo Harbor & $\checkmark$ Deer Bay exhalite & Hozer \\
\hline Nichols Bay & Trocadero Bay exhalite & Lime Point \\
\hline
\end{tabular}

Figure 7. Histogram of sulfur-isotopic values for sulfide mineral separates (pyrite, sphalerite, chalcopyrite, galena, pyrrhotite) from volcanogenic massive sulfide deposits in study area (fig. 1). Isotopically light pyrite sample is from the Barrier Islands No. 1 occurrence; barite sample is from the Lime Point barite deposit. All values in permil relative to Cañon Diablo Troilite standard. 
24 Studies by the U.S. Geological Survey in Alaska, 2005

Table 10. Sulfur-isotopic analyses of sulfide minerals and barite in stratabound mineral deposits on southern Prince of Wales Island and vicinity, southeastern Alaska.

[Minerals: cp, chalcopyrite; po, pyrrhotite; py, pyrite; sl, sphalerite]

\begin{tabular}{|c|c|c|c|c|c|c|c|}
\hline Sample & Description & $\begin{array}{c}\delta^{34} S \\
\text { value } \\
\text { (permil) }\end{array}$ & $\begin{array}{c}\delta^{34} S \\
\text { value } \\
\text { (permil) }\end{array}$ & $\begin{array}{c}\delta^{34} S \\
\text { value } \\
\text { (permil) }\end{array}$ & $\begin{array}{c}\delta^{34} S \\
\text { value } \\
\text { (permil) }\end{array}$ & $\begin{array}{c}\delta^{34} S \\
\text { value } \\
\text { (permil) }\end{array}$ & $\begin{array}{c}\delta^{34} S \\
\text { value } \\
\text { (permil) }\end{array}$ \\
\hline Mineral-------- & - & py & sl & po & cp & Bulk & Barite \\
\hline \multicolumn{8}{|c|}{ Moira Sound unit } \\
\hline \multicolumn{8}{|c|}{ Niblack deposit: } \\
\hline JS-00-28A & $\begin{array}{l}\text { Weakly layered pyritic massive sulfide with } \\
\text { minor sphalerite and chalcopyrite. }\end{array}$ & -- & -- & -- & -- & 7.0 & -- \\
\hline JS-00-28C & $\begin{array}{l}\text { Siliceous rock with abundant disseminated } \\
\text { fine-grained pyrite and minor chalco- } \\
\text { pyrite. }\end{array}$ & -- & -- & -- & -- & 10.4 & -- \\
\hline JS-00-28F & $\begin{array}{l}\text { Massive fine-grained magnetite and hema- } \\
\text { tite with abundant seams of pyrite and } \\
\text { chalcopyrite. }\end{array}$ & -0.5 & -- & -- & 0.8 & -- & -- \\
\hline JS-00-28G & $\begin{array}{l}\text { Complex mixture of fine-grained magne- } \\
\text { tite with carbonate, quartz, pyrite, and } \\
\text { chalcopyrite. }\end{array}$ & -- & -- & -- & -- & 7.9 & -- \\
\hline JS-00-28I & $\begin{array}{l}\text { Semimassive sulfide (pyrite and subequal } \\
\text { chalcopyrite) in chlorite schist with } \\
\text { minor quartz and sphalerite. }\end{array}$ & -- & -- & -- & -- & 9.9 & -- \\
\hline \multicolumn{8}{|c|}{ Moira Copper deposits: } \\
\hline MC-MS-1 & $\begin{array}{l}\text { Semimassive pyritic sulfide with abundant } \\
\text { chalcopyrite and quartz and minor chlo- } \\
\text { rite and sericite. }\end{array}$ & -- & -- & -- & -- & 8.8 & -- \\
\hline MC-MS-2 & $\begin{array}{l}\text { Semimassive pyrite with abundant quartz, } \\
\text { minor chlorite and sericite, and sparse } \\
\text { chalcopyrite. }\end{array}$ & 9.6 & -- & -- & -- & -- & -- \\
\hline MC-MS-3 & $\begin{array}{l}\text { Semimassive pyrite with quartz, minor } \\
\text { chlorite and sericite, and trace chalcopy- } \\
\text { rite and sphalerite. }\end{array}$ & 9.0 & -- & -- & -- & 8.7 & -- \\
\hline \multicolumn{8}{|c|}{ Lookout Mountain and Dama deposits: } \\
\hline LO-53/624.2 & $\begin{array}{l}\text { Layered massive sulfide composed of py- } \\
\text { rite, sphalerite, and minor chalcopyrite. }\end{array}$ & -- & -- & -- & -- & 9.3 & -- \\
\hline LO-61/573.0 & $\begin{array}{l}\text { Massive sulfide composed of fine-grained } \\
\text { chalcopyrite with minor pyrite and ma- } \\
\text { trix quartz and chlorite. }\end{array}$ & -- & -- & -- & 9.5 & -- & -- \\
\hline LO-99/290 & $\begin{array}{l}\text { Fine-grained metarhyolite with dissemina- } \\
\text { tions and veinlets of chalcopyrite and } \\
\text { pyrite, abundant fine-grained sericite, } \\
\text { minor sphalerite, and trace galena. }\end{array}$ & -- & -- & -- & 7.5 & -- & -- \\
\hline LO-99/367 & $\begin{array}{l}\text { Massive pyritic sulfide with matrix quartz } \\
\text { and sericite and trace sphalerite and } \\
\text { chalcopyrite. }\end{array}$ & 8.5 & -- & -- & -- & -- & -- \\
\hline LO-99/378 & $\begin{array}{l}\text { Altered rhyolite metatuff with abundant } \\
\text { disseminated pyrite and minor sphalerite } \\
\text { and chalcopyrite. }\end{array}$ & -- & -- & -- & 8.6 & -- & -- \\
\hline
\end{tabular}


Table 10. Sulfur-isotopic analyses of sulfide minerals and barite in stratabound mineral deposits on southern Prince of Wales Island and vicinity, southeastern Alaska.-Continued

\begin{tabular}{|c|c|c|c|c|c|c|c|}
\hline Sample & Description & $\begin{array}{c}\delta^{34} S \\
\text { value } \\
\text { (permil) }\end{array}$ & $\begin{array}{c}\delta^{34} S \\
\text { value } \\
\text { (permil) }\end{array}$ & $\begin{array}{c}\delta^{34} S \\
\text { value } \\
\text { (permil) }\end{array}$ & $\begin{array}{c}\delta^{34} S \\
\text { value } \\
\text { (permil) }\end{array}$ & $\begin{array}{c}\delta^{34} S \\
\text { value } \\
\text { (permil) }\end{array}$ & $\begin{array}{c}\delta^{34} S \\
\text { value } \\
\text { (permil) }\end{array}$ \\
\hline Mineral----------- & - & py & sl & po & cp & Bulk & Barite \\
\hline LO-99/469 & $\begin{array}{l}\text { Coarse-grained rhyolite lithic metatuff with } \\
\text { abundant matrix pyrite, sparse sphalerite, } \\
\text { and trace chalcopyrite. }\end{array}$ & 8.7 & -- & -- & -- & -- & -- \\
\hline \multicolumn{8}{|c|}{ Barrier Islands deposits: } \\
\hline JS-00-58 & $\begin{array}{l}\text { Sericite-altered rhyolite metatuff(?) with } \\
\text { moderate disseminated pyrite and trace } \\
\text { sphalerite. }\end{array}$ & 3.4 & -- & -- & -- & -- & -- \\
\hline BI1-MS & $\begin{array}{l}\text { Brecciated fine-grained massive pyrite with } \\
\text { quartz and sparse sericite, carbonate, and } \\
\text { chlorite. }\end{array}$ & -31.1 & -- & -- & -- & -- & -- \\
\hline B12-MS & $\begin{array}{l}\text { Semimassive pyrite with abundant sericite, } \\
\text { minor quartz, and trace sphalerite and } \\
\text { galena. }\end{array}$ & 2.8 & -- & -- & -- & -- & -- \\
\hline B17-MS & $\begin{array}{l}\text { Semimassive pyrite with quartz, chlorite, } \\
\text { and minor sericite. }\end{array}$ & 5.1 & -- & -- & -- & -- & -- \\
\hline \multicolumn{8}{|c|}{ Datzkoo Harbor occurrence: } \\
\hline JS-00-57A & $\begin{array}{l}\text { Semimassive pyritic sulfide with trace } \\
\text { sphalerite in quartz-chlorite-sericite } \\
\text { schist. }\end{array}$ & 3.8 & -- & -- & -- & -- & -- \\
\hline \multicolumn{8}{|c|}{ Nichols Bay Mine: } \\
\hline B19-MS-1H & $\begin{array}{l}\text { Fine-grained massive pyrrhotite (partially } \\
\text { oxidized) with abundant diopside(?), } \\
\text { minor pyrite, garnet, sericite, and } \mathrm{Mn} \\
\text { carbonate, and sparse }\end{array}$ & -- & -- & -2.8 & -- & -- & -- \\
\hline B19-MS2MS & $\begin{array}{l}\text { Fine-grained massive magnetite with minor } \\
\text { pyrite and sparse sphalerite associated } \\
\text { with abundant Mn carbonate and trace } \\
\text { quartz. }\end{array}$ & -0.8 & -- & -- & -- & -- & -- \\
\hline
\end{tabular}

Wales Group

Big Harbor deposits:

JS-00-29C Semimassive pyritic sulfide in siliceous schist with abundant chalcopyrite and trace sphalerite.

JS-00-29E Quartz-sericite schist with abundant disseminated pyrite and sparse chalcopyrite.

JS-00-31B Chloritic schist with abundant disseminated chalcopyrite and pyrite and sparse sphalerite.

JS-00-31D Semimassive sulfide composed of chalcopyrite, minor pyrite, and sparse sphalerite in chlorite schist.

JS-00-32A Siliceous exhalite composed of quartz, Mn carbonate, minor piemontite and barite, and trace sulfides.
16.3

$--$

16.6

17.4

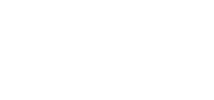

$-$$$
-1
$$$$
--\quad--
$$$$
--
$$$$
-
$$$$
--
$$ 
Table 10. Sulfur-isotopic analyses of sulfide minerals and barite in stratabound mineral deposits on southern Prince of Wales Island and vicinity, southeastern Alaska.-Continued

\begin{tabular}{|c|c|c|c|c|c|c|c|}
\hline Sample & Description & $\begin{array}{c}\delta^{34} S \\
\text { value } \\
\text { (permil) }\end{array}$ & $\begin{array}{c}\delta^{34} S \\
\text { value } \\
\text { (permil) }\end{array}$ & $\begin{array}{c}\delta^{34} S \\
\text { value } \\
\text { (permil) }\end{array}$ & $\begin{array}{c}\delta^{34} S \\
\text { value } \\
\text { (permil) }\end{array}$ & $\begin{array}{c}\delta^{34} S \\
\text { value } \\
\text { (permil) }\end{array}$ & $\begin{array}{c}\delta^{34} S \\
\text { value } \\
\text { (permil) }\end{array}$ \\
\hline Mineral----------. & 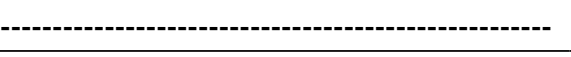 & py & sl & po & $\mathbf{c p}$ & Bulk & Barite \\
\hline 84AGKO39E & $\begin{array}{l}\text { Quartz vein with margins composed of } \\
\text { massive chalcopyrite, minor pyrite, } \\
\text { and trace sphalerite with some chloritic } \\
\text { wallrock. }\end{array}$ & -- & -- & -- & 16.5 & -- & -- \\
\hline \multicolumn{8}{|c|}{ Ruby Tuesday deposit: } \\
\hline JS-00-49B & $\begin{array}{l}\text { Quartz-rich schist with quartz veins and } \\
\text { minor disseminations of pyrite, sphaler- } \\
\text { ite, and galena and trace chalcopyrite. }\end{array}$ & 7.9 & 8.1 & -- & -- & -- & -- \\
\hline RT-81-9/211 & $\begin{array}{l}\text { Altered rhyolite metatuff(?) with abundant } \\
\text { disseminated pyrite (partially laminat- } \\
\text { ed), sparse sphalerite and chalcopyrite, } \\
\text { and trace galena. }\end{array}$ & 12.3 & -- & -- & -- & -- & -- \\
\hline RT-FS-MS & $\begin{array}{l}\text { Semimassive sphalerite with subequal } \\
\text { pyrite and galena and trace chalcopyrite } \\
\text { associated with quartz, feldspar, and } \\
\text { sparse sericite. }\end{array}$ & 9.5 & 7.3 & -- & -- & -- & -- \\
\hline RT-FS-MS2 & $\begin{array}{l}\text { Semimassive sphalerite with subequal py- } \\
\text { rite and galena, minor chalcopyrite with } \\
\text { quartz and sparse sericite, and small } \\
\text { volcanic rock fragments. }\end{array}$ & -- & 6.2 & -- & 7.1 & -- & -- \\
\hline \multicolumn{8}{|c|}{ Khayyam Mine (main workings): } \\
\hline JS-00-33B & $\begin{array}{l}\text { Sericite-chlorite with disseminations and } \\
\text { veins of pyrite, minor chalcopyrite, and } \\
\text { sparse sphalerite and magnetite. }\end{array}$ & 10.9 & -- & -- & -- & -- & \\
\hline JS-00-33C & $\begin{array}{l}\text { Massive granular pyritic sulfide with } \\
\text { abundant matrix chalcopyrite and minor } \\
\text { sphalerite. }\end{array}$ & -- & -- & -- & -- & 12.4 & -- \\
\hline JS-00-33D & $\begin{array}{l}\text { Sericite-chlorite with quartz boudins, mi- } \\
\text { nor chalcopyrite, pyrite, and pyrrhotite, } \\
\text { and sparse sphalerite. }\end{array}$ & -- & -- & 10.7 & 10.9 & -- & -- \\
\hline JS-00-33E & $\begin{array}{l}\text { Feldspathic(?) rock with disseminated py- } \\
\text { rite and pyrrhotite, minor chalcopyrite, } \\
\text { and sparse sphalerite. }\end{array}$ & -- & -- & -- & -- & 11.0 & -- \\
\hline JS-00-33F & $\begin{array}{l}\text { Massive fine-grained pyrrhotite with minor } \\
\text { coarse-grained pyrite and pyrite layers, } \\
\text { and sparse chalcopyrite and sphalerite. }\end{array}$ & 10.5 & -- & 10.4 & -- & -- & -- \\
\hline JS-00-33G & $\begin{array}{l}\text { Massive granular pyritic sulfide in a matrix } \\
\text { of chalcopyrite, minor sphalerite, and } \\
\text { quartz. }\end{array}$ & -- & -- & -- & -- & 12.1 & -- \\
\hline JS-00-33K & $\begin{array}{l}\text { Feldspathic(?) rock with abundant dis- } \\
\text { seminated pyrite and pyrrhotite, and } \\
\text { some disseminated magnetite, sparse } \\
\text { chalcopyrite, and trace sphalerite. }\end{array}$ & -- & -- & -- & 9.9 & -- & -- \\
\hline
\end{tabular}


Table 10. Sulfur-isotopic analyses of sulfide minerals and barite in stratabound mineral deposits on southern Prince of Wales Island and vicinity, southeastern Alaska.-Continued

\begin{tabular}{|c|c|c|c|c|c|c|c|}
\hline Sample & Description & $\begin{array}{c}\delta^{34} S \\
\text { value } \\
\text { (permil) }\end{array}$ & $\begin{array}{c}\delta^{34} S \\
\text { value } \\
\text { (permil) }\end{array}$ & $\begin{array}{c}\delta^{34} S \\
\text { value } \\
\text { (permil) }\end{array}$ & $\begin{array}{c}\delta^{34} S \\
\text { value } \\
\text { (permil) }\end{array}$ & $\begin{array}{c}\delta^{34} S \\
\text { value } \\
\text { (permil) }\end{array}$ & $\begin{array}{c}\delta^{34} S \\
\text { value } \\
\text { (permil) }\end{array}$ \\
\hline Mineral------ & 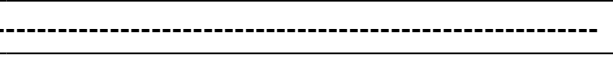 & py & sl & po & cp & Bulk & Barite \\
\hline JS-00-35B & $\begin{array}{l}\text { Sericite-quartz with abundant disseminated } \\
\text { pyrite and pyrrhotite, and minor chalco- } \\
\text { pyrite. }\end{array}$ & -- & -- & 13.6 & 14.7 & -- & -- \\
\hline \multicolumn{8}{|c|}{ Khayyam Mine (lower tram terminal): } \\
\hline JS-00-62A & $\begin{array}{l}\text { Massive granular pyritic sulfide with abundant } \\
\text { matrix chalcopyrite and minor sphalerite }\end{array}$ & -- & -- & -- & -- & 13.0 & -- \\
\hline JS-00-62C & $\begin{array}{l}\text { Massive granular pyritic sulfide with abundant } \\
\text { matrix sphalerite and minor chalcopyrite }\end{array}$ & 12.9 & 11.3 & -- & 12.0 & -- & -- \\
\hline JS-00-62E & $\begin{array}{l}\text { Massive granular pyritic sulfide with abundant } \\
\text { matrix sphalerite and chalcopyrite. }\end{array}$ & 12.4 & 11.5 & -- & 11.8 & -- & -- \\
\hline JS-00-62F & $\begin{array}{l}\text { Massive fine-grained chalcopyrite with minor } \\
\text { sphalerite and sparse quartz. }\end{array}$ & -- & 12.1 & -- & 11.9 & -- & -- \\
\hline \multicolumn{8}{|c|}{ Stumble-On Mine: } \\
\hline JS-00-36A & $\begin{array}{l}\text { Massive fine-grained pyrrhotite with abundant } \\
\text { chalcopyrite and minor sphalerite. }\end{array}$ & 12.2 & 12.0 & 12.3 & 11.8 & -- & -- \\
\hline JS-00-36B & $\begin{array}{l}\text { Massive granular pyritic sulfide with minor } \\
\text { chalcopyrite, interlayered with coarse- } \\
\text { grained sphalerite and quartz with dissemi- } \\
\text { nated chalcopyrite. }\end{array}$ & 12.9 & 13.3 & -- & 13.7 & -- & -- \\
\hline JS-00-36C & $\begin{array}{l}\text { Massive granular sphalerite with minor matrix } \\
\text { pyrite. }\end{array}$ & 14.2 & 13.7 & -- & -- & -- & -- \\
\hline JS-00-36D & $\begin{array}{l}\text { Massive fine-grained pyrrhotite with minor } \\
\text { coarse-grained pyrite and minor matrix } \\
\text { sphalerite and chalcopyrite. }\end{array}$ & -- & 13.4 & -- & 13.4 & -- & -- \\
\hline JS-00-36E & $\begin{array}{l}\text { Chlorite with abundant coarse-grained pyrite, } \\
\text { minor pyrrhotite and sphalerite, and sparse } \\
\text { chalcopyrite and magnetite. }\end{array}$ & 13.8 & -- & -- & -- & -- & -- \\
\hline \multicolumn{8}{|c|}{ Copper City Mine: } \\
\hline JS-00-54C & $\begin{array}{l}\text { Fine-grained jasper with lenses of coarse- } \\
\text { grained magnetite and minor quartz, sparse } \\
\text { pyrite and chalcopyrite, and trace sphaler- } \\
\text { ite. }\end{array}$ & 10.3 & -- & -- & -- & -- & -- \\
\hline JS-00-55A & $\begin{array}{l}\text { Fine-grained massive chalcopyrite and sphal- } \\
\text { erite with minor pyrite and quartz. }\end{array}$ & -- & -- & -- & -- & 12.8 & -- \\
\hline JS-00-55C & $\begin{array}{l}\text { Fine-grained pyritic massive sulfide with mi- } \\
\text { nor chalcopyrite and sphalerite and minor } \\
\text { matrix quartz. }\end{array}$ & -- & -- & -- & -- & 12.7 & -- \\
\hline JS-00-55D & $\begin{array}{l}\text { Magnetite and chlorite interlayered with } \\
\text { quartz, chalcopyrite, and sphalerite. }\end{array}$ & -- & -- & -- & 8.4 & -- & -- \\
\hline JS-00-55E & $\begin{array}{l}\text { Fine-grained massive pyritic sulfide with } \\
\text { abundant chalcopyrite, minor sphalerite and } \\
\text { quartz, and trace galena. }\end{array}$ & -- & -- & -- & -- & 12.8 & -- \\
\hline
\end{tabular}


Table 10. Sulfur-isotopic analyses of sulfide minerals and barite in stratabound mineral deposits on southern Prince of Wales Island and vicinity, southeastern Alaska.

\begin{tabular}{|c|c|c|c|c|c|c|c|}
\hline Sample & Description & $\begin{array}{c}\delta^{34} S \\
\text { value } \\
\text { (permil) }\end{array}$ & $\begin{array}{c}\delta^{34} S \\
\text { value } \\
\text { (permil) }\end{array}$ & $\begin{array}{c}\delta^{34} S \\
\text { value } \\
\text { (permil) }\end{array}$ & $\begin{array}{c}\delta^{34} S \\
\text { value } \\
\text { (permil) }\end{array}$ & $\begin{array}{c}\delta^{34} S \\
\text { value } \\
\text { (permil) }\end{array}$ & $\begin{array}{c}\delta^{34} S \\
\text { value } \\
\text { (permil) }\end{array}$ \\
\hline J Mineral- & 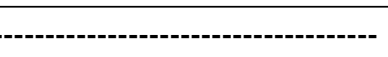 & py & sl & po & cp & Bulk & Barite \\
\hline
\end{tabular}

\section{Corbin Mine:}

JS-00-56C Pyritic massive sulfide with abundant matrix sericite and quartz, minor chalcopyrite, and trace sphalerite.

JS-00-56F Quartz-sericite with abundant disseminated pyrite and sparse chalcopyrite.

JS-00-56I Layered/laminated massive sulfide with subequal pyrite and sphalerite, minor quartz, sparse chalcopyrite, and trace galena.

Nutkwa Prospects:

JS-00-37A Quartz-sericite-chlorite schist with abundant disseminated pyrite and trace sphalerite and galena.

JS-00-37C Sericite-chlorite-quartz schist with abundant disseminated coarse-grained pyrite, minor sphalerite, and sparse chalcopyrite.

JS-00-39A Semimassive pyritic sulfide with abundant sphalerite, sparse chalcopyrite and galena, and matrix quartz, sericite, and chlorite.

JS-00-39C Semimassive sulfide with subequal finegrained pyrite and sphalerite; minor chalcopyrite and trace galena.

Keete Inlet Mine:

JS-00-53A Pyritic massive sulfide with minor chalcopyrite.

JS-00-53C Semimassive pyritic sulfide with matrix quartz and chlorite.

9.1

6.4

5.9

JS-00-53D

Pyritic massive sulfide with minor chalcopyrite, sphalerite, magnetite, quartz, and carbonate.

Hozer Prospect:

JS-00-51A Quartz-sericite schist with minor disseminated pyrite and trace chalcopyrite.

Trocadero Bay exhalite:

JS-00-42A Semimassive pyritic sulfide with matrix sericite, chlorite, and quartz.

JS-00-42C Quartz-sericite-chlorite schist with abundant disseminated pyrite.

Deer Bay exhalite:

JS-00-66 Quartz-sericite schist with disseminated pyrite and sparse chalcopyrite.

Cable Creek roadcut:

JS-00-65 Semimassive pyritic sulfide in quartz-sericite schist with trace chalcopyrite.

Lime Point barite deposit:

JS-00-50B Massive barite (replacement of limestone).

$--$

$--$

$--$ 
Table 11. Sulfur-isotopic analyses of metavolcanic and metasedimentary rocks of southern Prince of Wales Island and vicinity, southeastern Alaska.

\begin{tabular}{|c|c|c|c|c|}
\hline Field No. & Description & $\begin{array}{c}\delta^{34} S \\
\text { value } \\
\text { (permil) }\end{array}$ & $\begin{array}{l}\text { Latitude } \\
\left({ }^{\circ} \mathrm{N}\right)\end{array}$ & $\begin{array}{c}\text { Longitude } \\
\left({ }^{\circ} \mathrm{W}\right)\end{array}$ \\
\hline \multicolumn{5}{|c|}{ Moira Sound unit } \\
\hline 00SK220A & Mafic metavolcanic agglomerate. & 19.7 & 54.95694 & 132.16800 \\
\hline LO-99/512 & $\begin{array}{l}\text { Unaltered(?) fine-grained greenstone from the Lookout } \\
\text { Mountain Prospect, Niblack Mine area; probably } \\
\text { stratigraphic hanging wall. }\end{array}$ & 7.5 & 55.05972 & 132.14167 \\
\hline LO-99/345 & $\begin{array}{l}\text { Altered quartz-feldspar porphyry from the Lookout } \\
\text { Mountain Prospect, Niblack Mine area; probably } \\
\text { stratigraphic footwall. }\end{array}$ & 9.2 & 55.05972 & 132.14167 \\
\hline LO-53/630 & $\begin{array}{l}\text { Altered quartz-eye felsic metatuff from the Dama Prospect, } \\
\text { Niblack Mine area; uncertain whether stratigraphic } \\
\text { hanging wall or footwall. }\end{array}$ & 11.6 & 55.05972 & 132.14167 \\
\hline 00SK217A & Felsic metavolcanic breccia. & 1.1 & 54.99745 & 132.11100 \\
\hline 00SK225A & Metalimestone in carbonaceous phyllite. & 9.7 & 54.98308 & 132.30200 \\
\hline 00SK116A & Metalimestone in carbonaceous phyllite. & 3.7 & 55.33098 & 132.79700 \\
\hline 00SK048A & Calcareous wacke turbidite. & -1.4 & 54.96136 & 132.94700 \\
\hline OOSK009D & Graphitic semischist. & -9.6 & 54.73742 & 132.72900 \\
\hline 00SK148C & Carbonaceous phyllite. & 3.2 & 54.74082 & 132.75600 \\
\hline 00SK152A & Graphitic phyllite. & 3.2 & 55.24591 & 132.69300 \\
\hline
\end{tabular}

\section{Wales Group}

\begin{tabular}{|c|c|c|c|c|}
\hline JS-00-35C & $\begin{array}{l}\text { Garnet-bearing amphibolite from Khayyam deposit; } \\
\text { uncertain stratigraphic relations. }\end{array}$ & 13.2 & 55.29861 & 132.38611 \\
\hline 00SK011A & Amphibolite (metaintrusive). & 4.3 & 54.75697 & 132.72800 \\
\hline JS-00-34A & $\begin{array}{l}\text { Hornblende-bearing felsic gneiss from the Khayyam } \\
\text { deposit; uncertain stratigraphic relations. }\end{array}$ & 9.8 & 55.29861 & 132.38611 \\
\hline JS-00-29A & $\begin{array}{l}\text { Altered massive metarhyolite from wallrock (mine adit) } \\
\text { directly adjacent to the Big Harbor East deposit; } \\
\text { uncertain stratigraphic relations. }\end{array}$ & 15.1 & 55.37611 & 132.95361 \\
\hline JS-00-30 & $\begin{array}{l}\text { Sulfidic rhyolite crystal metatuff from outcrop } \sim 75 \mathrm{~m} \text { from } \\
\text { adit to the Big Harbor East deposit; uncertain } \\
\text { stratigraphic relations. }\end{array}$ & 16.8 & 55.37611 & 132.95361 \\
\hline 00SK168A & Sericitic marble. & -3.7 & 55.14529 & 132.07700 \\
\hline 00SK251A & Pyritic black argillite. & -10.2 & 55.06988 & 132.10600 \\
\hline 00SK327A & Graphitic quartzite. & -7.3 & 55.34372 & 132.48342 \\
\hline 00SK281A & $\begin{array}{l}\text { Graphitic semischist intercalated with felsic metavolcanic } \\
\text { semischist. }\end{array}$ & -6.7 & 55.21383 & 132.26500 \\
\hline 00SK321A & Pyritic semischist-metavolcanic rock. & -8.0 & 55.37311 & 132.37300 \\
\hline
\end{tabular}

structures and exhalites produces fine-grained sulfide and gangue minerals because of relatively fast precipitation during rapid cooling of the hydrothermal fluids. After initial formation on the sea floor, however, chimneys and related sulfide mounds commonly undergo extensive zone refining in which circulating hydrothermal fluids dissolve some minerals, such as anhydrite, recrystallize others, including common sulfides, and precipitate new phases, such as pyrite and amorphous silica. Studies of both modern and ancient VMS deposits that have undergone minimal deformation and metamorphism indicate that hydrothermal zone refining can, in many places, form complex textures and coarse grains in sulfide minerals, including euhedral crystals of sphalerite and pyrite as much as several centimeters in diameter (for example, Eldridge and others,
1983; Petersen and others, 2000; Slack and others, 2003). Primary textures are therefore difficult to identify with confidence in VMS deposits of the study area (fig. 1), except possibly in the Dama deposit, where conspicuous mineralogic layering of sulfides (fig. $2 G$ ) likely reflects alternating deposition of pyrite and sphalerite on the sea floor and not later metamorphic segregation, because this VMS deposit in the Moira Sound unit underwent only lower-greenschist-facies metamorphism. Similar layering locally in the Corbin deposit (fig. $3 B$ ) is also believed to be primary, although a metamorphic origin cannot be ruled out, given the greater deformational and amphibolitefacies overprint on this older Wales Group deposit.

Primary whole-rock and mineral compositions are believed to generally be preserved in the sulfide-rich samples. 
Except in deposits that underwent pervasive metamorphic recrystallization and (or) a high fluid flux during metamorphism, or late faulting, bulk compositions should approximate those that existed during sea-floor and sub-sea-floor mineralization. The major-element contents in sulfide minerals are also interpreted as being mainly primary, except for such VMS deposits as the Khayyam and Stumble-On that were metamorphosed to amphibolite grade. In such sulfides as pyrite from the Barrier Islands No. 2 deposit (figs. $2 H, 3 H$ ), very high Mn, $\mathrm{As}, \mathrm{Sb}, \mathrm{Se}$, and $\mathrm{Tl}$ contents (tables 5,6 ) likely reflect primary deposition at temperatures below $\sim 250^{\circ} \mathrm{C}$ (see Huston and others, 1995; Houghton and others, 2004). The very low $\delta^{34} \mathrm{~S}$ value $(-31.1$ permil) of pyrite from this deposit supports this interpretation because such values are generally limited to low-temperature BSR (for example, Machel, 2001). Fe contents in sphalerite are also believed to record early sea-floor

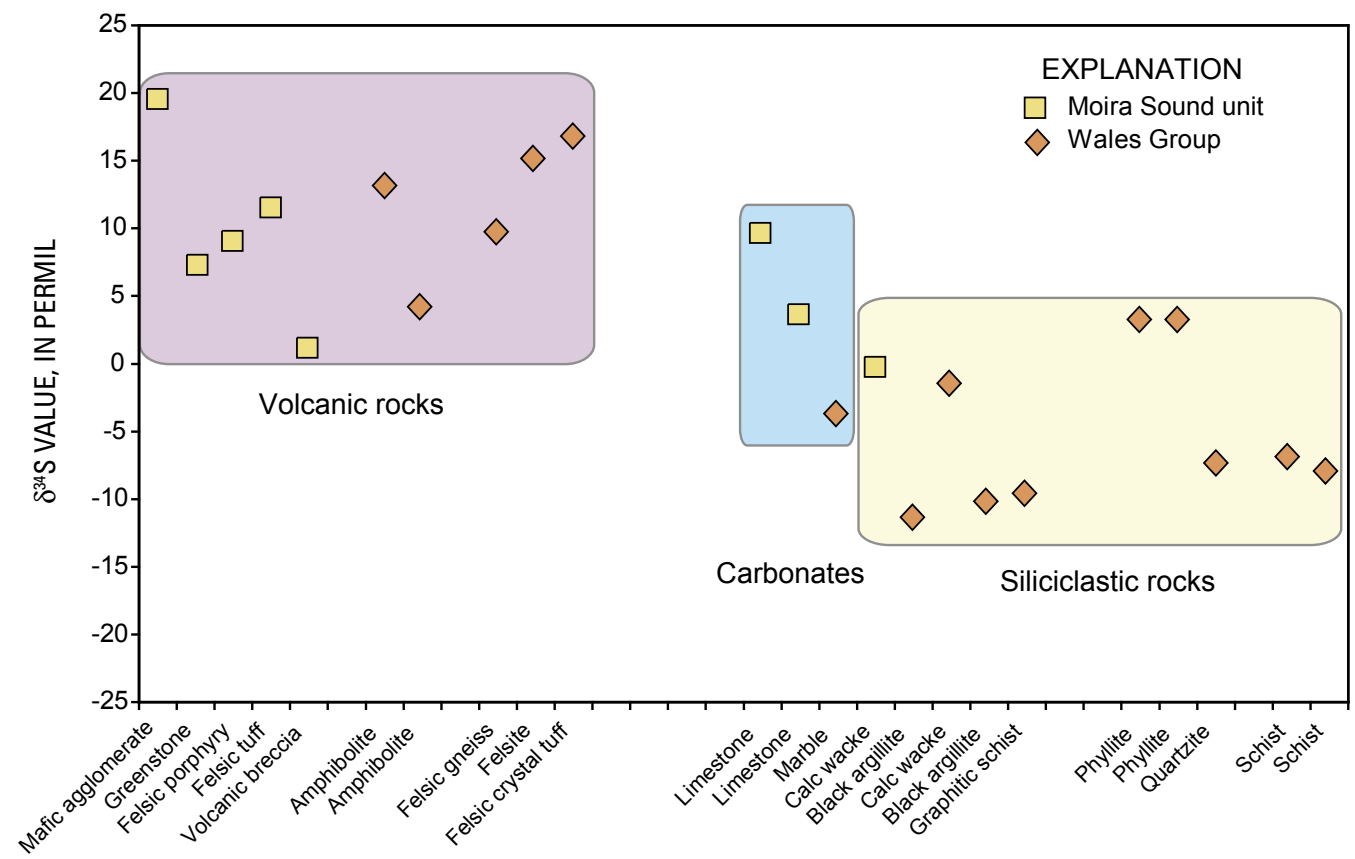

Figure 8. Range of $\delta^{34} S$ values for disseminated sulfide minerals separated from different rock types of the Wales Group and the Moira Sound unit.

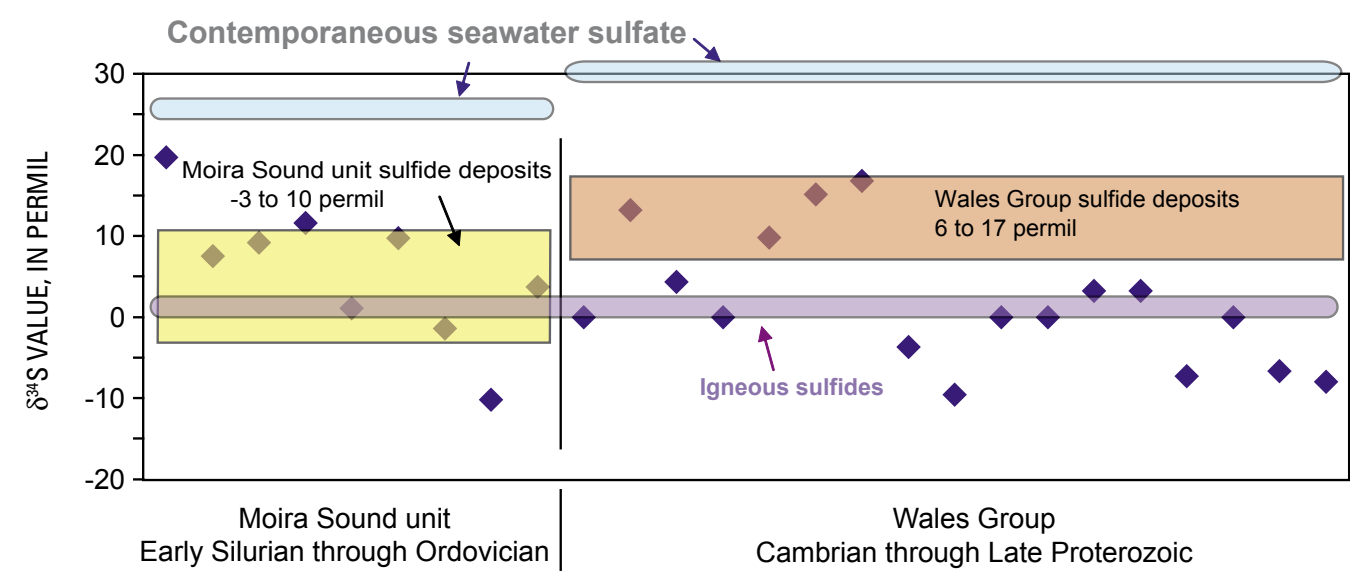

Figure 9. Summary of $\delta^{34} S$ values for sulfide minerals in volcanogenic massive sulfide (VMS) deposits of the Moira Sound unit (yellow) and the Wales Group (orange). $\delta^{34} S$ values for igneous sulfides (violet), $\delta^{34} S$ values for metasedimentary and metavolcanic country rocks (undivided) of the Moira Sound unit and the Wales Group (diamonds) (see fig. 8), and ranges of $\delta^{34} S$ values for contemporaneous seawater sulfate (blue) during the Ordovician through Early Silurian (Claypool and others, 1980) and the Late Proterozoic (Strauss, 1993; Ross and others, 1995; Hurtgen and others, 2002) are shown for reference. Note that $\delta^{34} S$ values for sulfide minerals from VMS deposits in the Moira Sound unit and for contemporaneous seawater sulfate are $\sim 5$ to 7 permil lower than those for sulfide minerals from VMS deposits in the Wales Group and for contemporaneous seawater sulfate. 
and (or) sub-sea-floor hydrothermal processes in deposits that have undergone limited metamorphic overprinting, such as the deposits in the Niblack area in the Moira Sound unit and in the Nutkwa area in the Wales Group. The Fe content in sphalerite from these two deposits varies widely within single thin sections, by as much as 72 and 129 relative percent, respectively. In contrast, the Fe content in sphalerite from the high-grademetamorphosed Khayyam and Stumble-On deposits varies by no more than 20 relative percent within single thin sections.

Additional support for the preservation of primary geochemical signatures comes from an apparent inverse correlation between Fe contents in sphalerite and average $\mathrm{Au}$ contents in the VMS deposits. Except for the Copper City deposit, for which reliable LA-ICP-MS analyses of sphalerite could not be obtained, owing to abundant inclusions of chalcopyrite and other sulfides, the two most $\mathrm{Au}$ rich deposits, at Lookout Mountain and Nutkwa (table 2), contain sphalerites with the lowest Fe contents (0.21-0.63 and $<0.16$ weight percent $F e$, respectively) measured in this study. The geologic resource for the Lookout Mountain deposit includes an average of $2.8 \mathrm{ppm}$ Au (Niblack Mining Corp., 2006, URL http://www.niblackmining.com/); the average Au content in the Nutkwa Main and North deposits is estimated at $2.3 \mathrm{ppm}$ (table 2). A database of VMS deposits throughout Alaska shows a similar trend, including for the Au-rich Greens Creek ore body on Admiralty Island (avg 5.8 ppm Au; Taylor and others, 1999), in which the highest gold grades ( $\geq 3 \mathrm{ppm} \mathrm{Au}$ ) occur in deposits that contain Fe-poor sphalerite $(<2$ mol percent FeS $[<1$ weight percent Fe]; Newberry and others, 1997b, fig. 25A). Because such Fe-poor sphalerite is generally pale in color (for example, yellow, light brown), it can generally be easily distinguished in hand specimen from dark-red-brown to black, Fe-rich sphalerite. Preferential occurrence of Fe-poor sphalerite in the gold-rich VMS deposits on Prince of Wales Island and elsewhere in Alaska is consistent with the data of Hannington and Scott (1989), who proposed that such features reflect mineralization at low temperatures $\left(150-250^{\circ} \mathrm{C}\right)$ under high-sulfidation $\left(\mathrm{a}_{\mathrm{S}_{2}}\right)$ conditions. Other aspects of this topic, including applications to mineral exploration, were discussed by Hannington and others (1999).

\section{Effects of Metamorphic Recrystallization}

Metamorphic processes have significantly affected most VMS deposits in the study area (fig. 1). The Wales Group deposits were overprinted by three tectonothermal events in the Late Proterozoic, Ordovician, and Early Devonian that in many samples produced new textures, mineral assemblages, mineral compositions, and sulfur-isotope distributions. VMS deposits in the Moira Sound unit were overprinted only by the Early Devonian metamorphic event and so show less deformation, recrystallization, and mineral-specific changes in chemical and sulfur-isotopic compositions. The wide variation in sulfide grain sizes in the Wales Group deposits (figs. 2,3) reflects varying degrees of postore deformation and metamorphism, and the extent of fluid flow (flux) associated with these processes, together with the inferred effects of earlier zone refining on and beneath the sea floor. The greatest textural changes occurred at the Khayyam and Stumble-On deposits, where amphibolitefacies metamorphism produced very coarse grained, porphyroblastic pyrite (fig. $2 A$ ) and coarse-grained, granoblastic pyrite and sphalerite (figs. $2 B, 2 C$ ). This metamorphism also formed abundant pyrrhotite (fig. 3A), which is absent from other VMS deposits in the study area except for the Nichols Bay No. 9 and 10 deposits (table 1), which are within the contact aureole of a large granitic pluton. Pyrrhotite commonly forms during high-grade metamorphism of such deposits by the breakdown of pyrite during desulfurization processes (for example, Vokes, 1969; Brooker and others, 1987). Uncommon sulfide-rich veins that cut massive sulfide and metamorphic fabrics in wallrocks at these and other Wales Group deposits probably reflect local remobilization of sulfide minerals by high fluid flow during the Ordovician metamorphic event (see Marshall and Gilligan, 1993; Marshall and others, 2000). Distinguishing effects of the greenschist- to amphibolite-facies Late Proterozoic and Ordovician metamorphic events from those of the greenschist-facies Early Devonian metamorphic event is beyond the scope of this study. However, because the earlier events were characterized by higher temperatures and pressures (Zumsteg and others, 2004), the Early Devonian metamorphism likely produced only minor recrystallization of sulfides and small-scale deformational features, except in areas within or adjacent to Devonian and younger faults or shear zones, which may have focused remobilization of the sulfides, including increased grain sizes (for example, Marignac and others, 2003). The absence of zoned sphalerite in all of the VMS deposits, assuming its original presence based on studies of essentially unmetamorphosed deposits elsewhere (Barton, 1970; Eldridge and others, 1983; Zaw and others, 1996; Slack and others, 2003), probably reflects chemical annealing during all three metamorphic events.

Metamorphic effects on whole-rock and mineral compositions of the sulfide-rich samples are believed to be generally minor. Except in the highly deformed and metamorphosed Khayyam and Stumble-On deposits, the scale of chemical equilibration reached in most of the VMS deposits during the various metamorphic events (combined effects) is estimated at $<10 \mathrm{~cm}$. This interpretation is based on widespread trace-element heterogeneity in the sulfide minerals (especially pyrite and sphalerite), as determined by in situ LA-ICP-MS analyses. In theory, if fractionation of trace elements among different sulfide minerals reached equilibrium conditions during metamorphism, these minerals would be mostly homogeneous (for example, Scott, 1983; Huston and others, 1995). However, because evidence for this equilibrium is generally not observed, metamorphic effects on the sulfide compositions were apparently limited spatially. Significant variations in $\mathrm{Mn}, \mathrm{As}, \mathrm{Sb}$, and $\mathrm{Tl}$ contents in pyrite from the Barrier Islands deposits (fig. 6) probably reflects the fact that these are the least deformed and least metamorphosed VMS deposits in the study area. 
In contrast to the compositional heterogeneity of sulfide minerals from most of the VMS deposits, those at Khayyam and Stumble-On display a more nearly homogeneous traceelement distribution. This contrast is shown, for example, by the relatively uniform $\mathrm{As}, \mathrm{Sb}$, and $\mathrm{Tl}$ contents in pyrite and $\mathrm{Co}$, As, $\mathrm{Hg}$, and In contents in sphalerite within the same samples, and even within different samples from the same deposit. Such homogeneity suggests a redistribution of trace elements among the sulfide minerals due to different fractionation factors and higher pressure-temperature conditions than those that occurred during sea-floor and sub-sea-floor mineralization. Some trace elements, such as $\mathrm{Hg}$, were probably lost to the metamorphic fluids, at least partly, during amphibolite-grade metamorphism of the Khayyam and Stumble-On deposits. This process is recorded by whole-rock data indicating that the $\mathrm{Hg}$ contents in sulfide-rich samples are about a tenth those in samples from other VMS deposits in the study area, measured at similar $\mathrm{Zn}$ contents (fig. 5E). Inclusion-free sphalerite grains from the Khayyam and Stumble-On deposits also have the lowest $\mathrm{Hg} / \mathrm{Fe}$ ratios, on the basis of LA-ICP-MS data (fig. $6 E$ ) that support this interpretation.

\section{Discriminating VMS Deposits in the Wales Group and the Moira Sound Unit}

Both geochemical and sulfur-isotopic data may be used to distinguish the VMS deposits in Late Proterozoic through Cambrian rocks of the Wales Group from those in Ordovician through Early Silurian rocks of the Moira Sound unit. A first-order discrimination may be made by using basic geologic information, together with immobile-element geochemical signatures of the metabasaltic host rocks. The stratigraphic settings of a few deposits, however, such as the Copper City and Ruby Tuesday (CC and RTF, respectively, fig. 1), are poorly constrained, and so other criteria are needed for accurate formational assignment. Within the VMS deposits, textures and mineral assemblages are not reliable guides except in such deposits as the Khayyam and Stumble-On (KY and SO, respectively, fig. 1), where highgrade Ordovician metamorphism produced coarse-grained porphyroblastic pyrite, granoblastic pyrite and sphalerite, and abundant pyrrhotite (figs. $2 A-2 C, 3 A$ ). These features are absent in the VMS deposits in the Moira Sound unit, owing to uniformly lower grade overprints during the Early Devonian metamorphic event (Zumsteg and others, 2004). However, because many other VMS deposits in the Wales Group have sulfide textures and sulfide assemblages similar to those in the Moira Sound unit, other criteria must be used to distinguish them. Geochemical data for sulfide-rich rocks can also provide valuable insight, such as the tendency for the VMS deposits in the Moira Sound unit to have proportionately higher Ag contents relative to base metals and $\mathrm{Au}$, in comparison with those in the Wales Group (fig. 4B).

Sulfur-isotopic data for sulfide minerals in VMS deposits of the study area (fig. 1) can also be used to discriminate the VMS deposits in the Wales Group from those in the Moira Sound unit. Although minor overlap exists, $\delta^{34} S$ values for sulfides in the Wales Group average $\sim 5$ to 7 permil higher than for those in the Moira Sound unit (fig. 8). This difference in $\delta^{34} \mathrm{~S}_{\text {sulfide }}$ values reflects seawater sulfate as the dominant sulfur source of the VMS deposits, and the related fact that the $\delta^{34} \mathrm{~S}$ values of contemporaneous seawater sulfate during the Late Proterozoic through Cambrian were slightly higher than during the Ordovician through Early Silurian.

From a mineral-resource standpoint, base-metal grades vary widely among VMS deposits in both the Wales Group and Moira Sound unit. Overall, the VMS deposits in the Wales Group appear to have a lower potential for high silver grades than those in the Moira Sound unit, whereas the VMS deposits in both groups may have either high or low gold grades. On the basis of limited data, we suggest that future exploration in the study area (fig. 1) for preciousmetal-rich VMS deposits should focus on the Moira Sound unit, including the use of Fe-poor sphalerite as a guide to Au-rich VMS deposits. On Prince of Wales Island, such $\mathrm{Fe}$-poor sphalerite is characteristically yellow or yellowish brown and is generally discernible in both hand specimens and drill cores. The Copper City and Nutkwa areas, which are underlain by the Wales Group, also have a potential for Au-rich VMS deposits (table 2).

\section{Acknowledgments}

We thank K.M. Maas of the U.S. Forest Service, Juneau, Alaska, for his assistance during fieldwork. Advice during planning of the study was provided by L.E. Burns of the Alaska Department of Geological and Geophysical Surveys, Fairbanks; D.J. Grybeck of Bellingham, Wash.; R.P. Harris of Sealaska Corp., Juneau; and D. Hedderly-Smith of Park City, Utah. C.T. Barrie of Ottawa, Ontario; M.J. Gray of Rubicon Minerals, Vancouver, British Columbia; and S.M. Weekes of Abacus Minerals, Vancouver, British Columbia, supplied information on specific deposits in the study area. The manuscript was improved by the detailed comments of R.R. Seal II, J.M. Hammarstrom, and R.G. Luedke of the USGS. 


\section{References Cited}

Adamson, D.W., and Gray, M.J., 1995, Report of exploration activities up to November 1, 1995, on the Niblack property, Southeast Alaska: Vancouver, British Columbia, report to Abacus Minerals Corp., 30 p.

Ahsan, S.N., and Mallick, K.A., 1999, Geology and genesis of barite deposits of Lasbela and Khuzdar districts, Balochistan, Pakistan: Resource Geology, v. 49, no. 2, p. 105-111.

Axelsson, M.D., and Rodushkin, I., 2001, Determination of major and trace elements in sphalerite using laser ablation double focusing sector field ICP-MS: Journal of Geochemical Exploration, v. 72, no. 2, p. 81-89.

Barrie, C.T., 1984, The geology of the Khayyam and StumbleOn deposits, Prince of Wales Island, Alaska: Austin, University of Texas, M.S. thesis, $171 \mathrm{p}$.

Barrie, C.T., and Hannington, M.D., eds., 1999, Volcanichosted massive sulfide deposits; processes and examples in modern and ancient settings: Reviews in Economic Geology, v. 8,408 p.

Barrie, C.T., and Kyle, J.R., 1988, Geology, geochemistry, and tectonic setting of the Khayyam and Stumble-On massive sulfide deposits, Prince of Wales Island, Alaska: Economic Geology, v. 83, no. 1, p. 182-196.

Barton, P.B., Jr., 1970, Sulfide petrology, in Morgan, B.A., ed., Fiftieth anniversary symposia; mineralogy and petrology of the upper mantle, sulfides, mineralogy and geochemistry of non-marine evaporites: Mineralogical Society of America Special Paper 3, p. 187-198.

Berg, H.C., 1984, Regional geologic summary, metallogenesis, and mineral resources of southeastern Alaska: U.S. Geological Survey Open-File Report 84-572, 298 p.

Breit, G.N., Simmons, E.C., and Goldhaber, M.B., 1985, Dissolution of barite for the analysis of strontium isotopes and other chemical and isotopic variations using aqueous sodium carbonate: Chemical Geology, v. 52, no. 3-4, p. 333-336.

Brooker, D.D., Craig, J.R., and Rimstidt, J.D., 1987, Ore metamorphism and pyrite porphyroblast development at the Cherokee mine, Ducktown, Tennessee: Economic Geology, v. 82 , no. 1 , p. $72-86$.

Brooks, A.H., 1902, Preliminary report on the Ketchikan mining district, Alaska: U.S. Geological Survey Professional Paper 1, $120 \mathrm{p}$.

Bufvers, J., 1967, History of mines and prospects, Ketchikan district, prior to 1952: Alaska Division of Geological and Geophysical Surveys Special Report 1, 32 p.
Butler, I.B., and Nesbitt, R.W., 1999, Trace element distributions in the chalcopyrite wall of a black smoker chimney: insights from laser ablation inductively coupled plasma mass spectrometry (LA-ICP-MS): Earth and Planetary Science Letters, v. 167, no. 3-4, p. 335-345.

Callaghan, T., 2001, Geology and host-rock alteration of the Henty and Mount Julia gold deposits, western Tasmania: Economic Geology, v. 96, no. 5, p. 1073-1088.

Casselman, S., and Bohme, D., 1997, Hetta Inlet project, Alaska, 1996 annual report to Sealaska Corporation: Vancouver, British Columbia, American Copper and Nickel Co., Inc., 29 p.

CETAC Technologies, 2000, GeoPro ${ }^{\mathrm{TM}}$ software user's guide: Omaha, Nebr., 87 p.

Chapin, T., 1916, Mining developments in southeastern Alaska, in Brooks, A.H., and others, Mineral resources of Alaska; report on progress of investigations in 1915: U.S. Geological Survey Bulletin 642, p. 73-104.

Chapin, T., 1918, Mining developments in the Ketchikan and Wrangell mining districts, in Brooks, A.H., and others, Mineral resources of Alaska; report on progress of investigations in 1916: U.S. Geological Survey Bulletin 662, p. 63-75.

Claypool, G.E., Holser, W.T., Kaplan, I.R., Sakai, H., and Zak, I., 1980, The age curves of sulfur and oxygen isotopes in marine sulfate and their mutual interpretation: Chemical Geology, v. 28, no. 3-4, p. 199-260.

Craig, J.R., 1980, Stratiform sulfide mineralization in the central U.S. Appalachians: Norges Geologiske Unders $\emptyset$ kelse Bulletin 57, no. 360, p. 295-325.

Eldridge, C.S., Barton, P.B., Jr., and Ohmoto, H., 1983, Mineral textures and their bearing on the formation of the Kuroko orebodies, in Ohmoto, H., and Skinner, B.J., eds., The Kuroko and related volcanogenic massive sulfide deposits: Economic Geology Monograph 5, p. 241-281.

Elmendorf, W.J., 1920, Barite deposit at Lime Point, Prince of Wales Island: Alaska Territorial Department of Mines Miscellaneous Report MR-119-1, 9 p.

Foley, J.Y., Light, T.D., Nelson, S.W., and Harris, R.A., 1997, Mineral occurrences associated with mafic-ultramafic and related alkaline complexes in Alaska, in Goldfarb, R.J., and Miller, L.D., eds., Mineral deposits of Alaska: Economic Geology Monograph 9, p. 396-449.

Forbes, R.B., Evans, B.W., and Bundtzen, T.K., 1995, Tectonic significance of piemontite schists in the Wales Group, Alexander terrane, Prince of Wales Island, southeastern Alaska [abs.]: Geological Society of America Abstracts with Programs, v. 27, no. 5, p. 19. 
Fosse, E.L., 1946, Exploration of the copper-sulfur deposit, Khayyam and Stumble-On properties, Prince of Wales Island, Alaska: U.S. Bureau of Mines Report of Investigations 3942, 8 p.

Fowler, H.M., 1948, Report of the Lime Point barite occurrence (Prince of Wales Island): Alaska Territorial Department of Mines Property Examination PE-119-21, 4 p.

Fowler, H.M, 1949, Report on the Polymetal lode, Prince of Wales Island, Alaska: Alaska Territorial Department of Mines Property Examination PE-119-22, 3 p.

Franklin, J.M., Gibson, H.L., Jonasson, I.R., and Galley, A.G., 2005, Volcanogenic massive sulfide deposits: Economic Geology, 100th anniversary volume, 1905-2005, p. $523-560$.

Gehrels, G.E., 1990, Late Proterozoic through Cambrian metamorphic basement of the Alexander terrane on Long and Dall Islands, Southeast Alaska: Geological Society of America Bulletin, v. 102, no. 6, p. 760-767.

Gehrels, G.E., 1992, Geologic map of the southern Prince of Wales Island, southeastern Alaska: U.S. Geological Survey Miscellaneous Investigations Series Map I-2169, scale $1: 63,360$.

Gehrels, G.E., and Berg, H.C., 1992, Geologic map of southeastern Alaska: U.S. Geological Survey Miscellaneous Investigations Series Map I-1867, 24 p., scale 1:600,000.

Gehrels, G.E., Berg, H.C., and Saleeby, J.B., 1983, Ordovician-Silurian volcanogenic massive sulfide deposits on southern Prince of Wales Island and the Barrier Islands, southeastern Alaska: U.S. Geological Survey Open-File Report 83-318, 10 p.

Gehrels, G.E., Butler, R.F., and Bazard, D.R., 1996, Detrital zircon geochronology of the Alexander terrane, southeastern Alaska: Geological Society of America Bulletin, v. 108, no. 6 , p. $722-734$.

Gehrels, G.E., and Saleeby, J.B., 1987, Geology of southern Prince of Wales Island, southeastern Alaska: Geological Society of America Bulletin, v. 98, no. 2, p. 123-137.

Giesemann, A., Jäger, H.-J., Norman, A.L., Krouse, H.R., and Brand, W.A., 1994, On-line sulfur-isotope determination using an elemental analyzer coupled to a mass spectrometer: Analytical Chemistry, v. 66, no. 18, p. 2816-2819.

Green, D., 2006, Niblack-a gold-rich (Zn-Cu-Ag-Au) volcanogenic massive sulfide system, Prince of Wales Island, Southeast Alaska [abs.]: Alaska Miners Association Annual Convention, Anchorage, 2006, Abstracts, p. 27-29.
Hannington, M.D., and Scott, S.D., 1989, Sulfidation equilibria as guides to gold mineralization in volcanogenic massive sulfides: evidence from sulfide mineralogy and the composition of sphalerite: Economic Geology, v. 84, no. 7, p. 1978-1995.

Hannington, M.D., Jonasson, I.R., Herzig, P.M., and Petersen, S., 1995, Physical and chemical processes of seafloor mineralization at mid-ocean ridges, in Humphris, S.E., Zierenberg, R.A., Mullineaux, L.S., and Thomson, R.E., eds., Seafloor hydrothermal systems; physical, chemical, biological, and geological interactions: American Geophysical Union Monograph 91, p. 115-157.

Hannington, M.D., Poulsen, K.H., Thompson, J.F.H., and Sillitoe, R.H., 1999, Volcanogenic gold in the massive sulfide environment, in Barrie, C.T., and Hannington, M.D., eds., Volcanic-associated massive sulfide deposits; processes and examples in modern and ancient settings: Reviews in Economic Geology, v. 8, p. 325-356.

Hattie, K., Beischer, G., Shriver, N., and Ashleman, J., 1996, Hetta Inlet project, Alaska, annual report for 1995 to Sealaska Corporation: American Copper and Nickel Co., Inc., $35 \mathrm{p}$.

Herreid, G., 1964, Geology of the Niblack anchorage area, southeastern Alaska: Alaska Division of Geological and Geophysical Surveys Geology Report 5, 10 p.

Herreid, G., Bundtzen, T.K., and Turner, D.L., 1978, Geology and geochemistry of the Craig A-2 quadrangle, Prince of Wales Island, southeastern Alaska: Alaska Division of Geological and Geophysical Surveys Geologic Report 48, 49 p.

Houghton, J.L., Shanks, W.C., III, and Seyfried, W.E., Jr., 2004, Massive sulfide deposition and trace element remobilization in the Middle Valley sediment-hosted hydrothermal system, northern Juan de Fuca Ridge: Geochimica et Cosmochimica Acta, v. 68, no. 13, p. 2863-2873.

Hurtgen, M.T., Arthur, M.A., Suits, N.S., and Kaufman, A.J., 2002, The sulfur isotopic composition of Neoproterozoic seawater sulfate; implications for a snowball Earth?: Earth and Planetary Science Letters, v. 203, no. 1, p. 413-429.

Huston, D.L., Sie, S.H., Suter, G.F., Cooke, D.R., and Both, R.A., 1995, Trace elements in sulfide minerals from eastern Australian volcanic-hosted massive sulfide deposits; part I. Proton microprobe analyses of pyrite, chalcopyrite, and sphalerite, and part II. Selenium levels in pyrite; comparison with $\delta^{34} \mathrm{~S}$ values and implications for the source of sulfur in volcanogenic hydrothermal systems: Economic Geology, v. 90 , no. 5, p. 1167-1196.

Janecky, D.R., and Shanks, W.C., III, 1988, Computational modeling of chemical and sulfur isotopic reaction processes in seafloor hydrothermal systems; chimneys, massive sulfides, and subjacent alteration zones: Canadian Mineralogist, v. 26, p. 805-825. 
Karl, S.M., Haeussler, P.J., Mortensen, J.K., Layer, P.W., Savage, N., Wardlaw, B.R., Harris, A.G., Murchey, B., and Blome, C.D., 1999, New stratigraphic and isotopic constraints on the depositional and deformational history of the Alexander terrane, southeastern Alaska [abs.]: Geological Society of America Abstracts with Programs, v. 31, no. 6, p. 68.

Kelley, K.D., Dumoulin, J.A., and Jennings, S., 2004, The Anarraaq $\mathrm{Zn}-\mathrm{Pb}-\mathrm{Ag}$ and barite deposit, northern Alaska; evidence for replacement of carbonate by barite and sulfides: Economic Geology, v. 99, no. 7, p. 1577-1591.

Ketner, K.B., 1975, Replacement barite deposit, southern Independence Mountains, Nevada: U.S. Geological Survey Journal of Research, v. 3, no. 5, p. 547-551.

Kucinski, R., 1987, Geology and mineralization of the Ruby Tuesday claim block, Prince of Wales Island, Southeast Alaska: Fairbanks, University of Alaska, M.S. thesis, 105 p.

Lydon, J.W., 1988, Volcanogenic massive sulphide deposits. Part 2. Genetic models: Geoscience Canada, v. 15, p. 43-65.

Maas, K.M., Bittenbender, P.E., and Still, J.C., 1995, Mineral investigations in the Ketchikan mining district, southeastern Alaska: U.S. Bureau of Mines Open File Report 11-95, 606 p.

Maas, K.M., Still, J.C., Clough, A.H., and Oliver, L.K., 1991, Mineral investigations in the Ketchikan mining district, Alaska, 1990; southern Prince of Wales Island and vicinity: U.S. Bureau of Mines Open File Report 33-91, 138 p.

Machel, H.G., 2001, Bacterial and thermochemical sulfate reduction in diagenetic settings-old and new insights: Sedimentary Geology, v. 140, no. 1-2, p. 143-175.

Marignac, C., Diagana, B., Cathelineau, M., Boiron, M.-C., Banks, D., Fourcade, S., and Vallance, J., 2003, Remobilisation of base metals and gold by Variscan metamorphic fluids in the South Iberian pyrite belt; evidence from the Tharsis VMS deposit: Chemical Geology, v. 194, no. 1-3, p. 143-165.

Marshall, B., and Gilligan, L.B., 1993, Remobilization, syntectonic processes and massive sulphide deposits: Ore Geology Reviews, v. 8, no. 1-2, p. 39-64.

Marshall, B., Vokes, F.M., and Larocque, A.C.L., 2000, Regional metamorphic remobilization; upgrading and formation of ore deposits, in Spry, P.G., Marshall, B., and Vokes, F.M., eds., Metamorphosed and metamorphogenic ore deposits: Reviews in Economic Geology, v. 11, no. p. 19-38.

McClelland, W.C., Gehrels, G.E., and Saleeby, J.B., 1992, Upper Jurassic-Lower Cretaceous basinal strata along the Cordilleran margin; implications for the accretionary history of the Alexander-Wrangellia-Peninsular terrane: Tectonics, v. 11 , no. 4 , p. $823-835$.
Newberry, R.J., and Brew, D.A., 1999, Chemical and isotopic data for rocks and ores from the Upper Triassic Greens Creek and Woewodski Island volcanogenic massive sulfide deposits, southeastern Alaska, in Kelley, K.D., ed., Geologic studies in Alaska by the U.S. Geological Survey, 1997: U.S. Geological Survey Professional Paper 1614, p. 35-55.

Newberry, R.J., Allegro, G.L., Cutler, S.E., Hagen-Levelle, J.H., Adams, D.D., Nicholson, L.C., Weglarz, T.B., Bakke, A.A., Clautice, K.H., Coulter, G.A., Ford, M.J., Myers, G.L., and Szumigala, D.J., 1997a, Skarn deposits of Alaska, in Goldfarb, R.J., and Miller, L.D., eds., Mineral deposits of Alaska: Economic Geology Monograph 9, p. 355-395.

Newberry, R.J., Crafford, T.C., Newkirk, S.R., Young, L.E., Nelson, S.W., and Duke, N.A., 1997b, Volcanogenic massive sulfide deposits of Alaska, in Goldfarb, R.J., and Miller, L.D., eds., Mineral deposits of Alaska: Economic Geology Monograph 9, p. 120-150.

Nokleberg, W.J., Parfenov, L.M., Monger, J.W.H., Norton, I.O., Khanchuk, A.I., Stone, D.B., Scotese, C.R., Scholl, D.W., and Fujita, K., 2001, Phanerozoic tectonic evolution of the Circum-North Pacific: U.S. Geological Survey Professional Paper 1626, 122 p.

Norman, M., Robinson, P., and Clark, D., 2003, Major- and trace-element analyses of sulfide ores by laser-ablation ICP-MS, solution ICP-MS, and XRF; new data on international reference materials: Canadian Mineralogist, v. 41, p. 293-305.

Ohmoto, H., 1986, Stable isotope geochemistry of ore deposits, in Valley, J.W., Taylor, H.P., Jr., and O'Neil, J.R., eds., Stable isotopes in high temperature geological processes: Washington, D.C., Mineralogical Society of America Reviews in Mineralogy, v. 16, p. 491-559.

Peek, B.C., 1975, Geology and mineral deposits of the Niblack anchorage area, Prince of Wales Island, Alaska: Fairbanks, University of Alaska, M.S. thesis, 50 p.

Petersen, S., Herzig, P.M., and Hannington, M.D., 2000, Third dimension of a presently forming VMS deposit; TAG hydrothermal mound, Mid-Atlantic Ridge, $26^{\circ} \mathrm{N}$ : Mineralium Deposita, v. 35, no. 2-3, p. 233-259.

Ridley, W.I., 2000, The ICP-MS laser microprobe; a new geochemical tool: Trends in Geochemistry, v. 1, p. 1-14.

Ridley, W.I., and Lichte, F.E., 1998, Major, trace, and ultratrace element analysis by laser ablation ICP-MS, in McKibben, M.A., Shanks, W.C., III, and Ridley, W.I., eds., Applications of microanalytical techniques to understanding mineralizing processes: Reviews in Economic Geology, v. 7, p. 199-215. 
Ross, G.M., Bloch, J.D., and Krouse, H.R., 1995, Neoproterozoic strata of the southern Canadian Cordillera and the isotopic evolution of seawater sulfate: Precambrian Research, v. 73, no. $1-4$, p. 71-99.

Scott, S.D., 1983, Chemical behaviour of sphalerite and arsenopyrite in hydrothermal and metamorphic environments: Mineralogical Magazine, v. 47, no. 4, p. 427-435.

Seyfried, W.E., Jr., and Shanks, W.C., III, 2004, Alteration and mass transport in high-temperature systems at mid-ocean ridges; controls on chemical and isotopic evolution of axial vent fields, in Elderfield, H., and Davis, E., eds., Hydrology of the ocean crust: Cambridge, U.K., Cambridge University Press, p. 451-494.

Shanks, W.C., III, 2001, Stable isotopes in seafloor hydrothermal systems; vent fluids, hydrothermal deposits, hydrothermal alteration, and microbial processes, in Valley, J.W., and Cole, D.R., eds., Stable isotope geochemistry: Reviews in Mineralogy and Geochemistry, v. 43, p. 469-525.

Shanks, W.C., III, Böhlke, J.K., and Seal, R.R., II, 1995, Stable isotopes in mid-ocean ridge hydrothermal systems; interaction between fluids, minerals and organisms, in Humphris, S.E., Zierenberg, R.A., Mullineaux, L.S., and Thomson, R.E., eds., Seafloor hydrothermal systems; physical, chemical, biological, and geological interactions: American Geophysical Union Monograph 91, p. 194-221.

Shanks, W.C., III, Bischoff, J.L., and Rosenbauer, R.J., 1981, Seawater sulfate reduction and sulfur isotope fractionation in basaltic systems; interaction of seawater with fayalite and magnetite at $200-350^{\circ} \mathrm{C}$ : Geochimica et Cosmochimica Acta, v. 45, no. 11, p. 1977-1995.

Slack, J.F., Foose, M.P., Flohr, M.J.K., Scully, M.V., and Belkin, H.E., 2003, Exhalative and subseafloor replacement processes in the formation of the Bald Mountain massive sulfide deposit, northern Maine, in Goodfellow, W.D., McCutcheon, S.R., and Peter, J.M., eds., Massive sulfide deposits of the Bathurst mining camp, New Brunswick, and northern Maine: Economic Geology Monograph 11, p. 513-547.

Spry, P.G., Peter, J.M., and Slack, J.F., 2000, Meta-exhalites as exploration guides to ore, in Spry, P.G., Marshall, B., and Vokes, F.M., eds., Metamorphosed and metamorphogenic ore deposits: Reviews in Economic Geology, v. 11, p. 163-201.

Strauss, H., 1993, The sulfur isotopic record of Precambrian sulfates; new data and a critical evaluation of the existing record: Precambrian Research, v. 63, no. 3-4, p. 225-246.

Taylor, C.D., 1997, An arc-flank to back-arc transect; metallogeny of Late Triassic volcanogenic massive sulfide occurrences of the Alexander terrane, southeastern Alaska and British Columbia [abs.]: Society of Economic Geologists Neves Corvo Field Conference, Lisbon, Portugal, 1997, Abstracts and Program, p. 68.
Taylor, C.D., Premo, W.R., Leventhal, J.S., Meier, A.L., Johnson, C.A., Newkirk, S.R., Hall, T.E., Lear, K.G., and Harris, A.G., 1999, The Greens Creek deposit, southeastern Alaska; a VMS-SEDEX hybrid, in Stanley, C.J., Rankin, A.H., Bodnar, R.J., Naden, J., Yardley, B.W.D., Criddle, A.J., Hagni, R.D., Gize, A.P., Pasava, J., Fleet, A.J., Seltmann, R., Halls, C., Stemprok, M., Williamson, B., Herrington, R.J., Hill, R.E.T., Prichard, H.M., Wall, F., Williams, C.T., McDonald, I., Wilkinson, J.J., Cooke, D., Cook, N.J., Marshall, B.J., Spry, P.G., Zaw, K., Meinert, L.D., Sundblad, K., Scott, P.W., Clark, S.H.B., Valsami-Jones, E., Beukes, N.J., Stein, H.J., Hannah, J.L., Neubauer, F., Blundell, D.J., Alderton, D.H.M., Smith, M.P., Mulshaw, S., and Ixer, R.A., eds., Mineral deposits; processes to processing: Society for Geology Applied to Mineral Deposits Biennial Meeting, 5th, and International Association on the Genesis of Ore Deposits Quadrennial Symposium, 10th, London, U.K., 1999, Proceedings, v. 1, p. 597-600.

Terry, D.A., and Gibson, K., 1998, 1998 southeast Alaska generative project, summary report on Sealaska Native Corporation properties: Vancouver, British Columbia, Boliden Ltd., 11 p.

Thompson, T.B., 1988, Geology and uranium-thorium mineral deposits of the Bokan Mountain granite complex, southeastern Alaska: Ore Geology Reviews, v. 3, no. 1-3, p. 193-210.

Thurston, P.B., 1994, Hetta Inlet property, Prince of Wales Island, Alaska, 1993 progress report [to Sealaska Native Corporation]: Vancouver, British Columbia, American Copper and Nickel Co., Inc., 44 p.

Tuttle, M.L., Goldhaber, M.B., and Williamson, D.L., 1986, An analytical scheme for determining forms of sulphur in oil shales and associated rocks: Talanta, v. 33, no. 12, p. 953-961.

Twenhofel, W.S., Reed, J.C., and Gates, G.O., 1949, Some mineral investigations in southeastern Alaska: U.S. Geological Survey Bulletin 963-A, 45 p.

Vokes, F.M., 1969, A review of the metamorphism of sulphide deposits: Earth-Science Reviews, v. 5, no. 2, p. 99-143.

Watkinson, D.H., and Melling, D.R., 1992, Hydrothermal origin of platinum-group mineralization in low-temperature copper sulfide-rich assemblages, Salt Chuck intrusion, Alaska: Economic Geology, v. 87, no. 1, p. 175-184.

Watling, R.J., Herbert, H.K., and Abell, I.D., 1995, The application of laser ablation-inductively coupled plasma-mass spectrometry (LA-ICP-MS) to the analysis of selected sulphide minerals: Chemical Geology, v. 124, no. 1-2, p. 67-81. 
Wilson, S.A., Ridley, W.I., and Koenig, A.E., 2002, Development of sulfide calibration standards for the laser ablation inductively-coupled plasma mass spectrometry technique: Journal of Atomic Spectrometry, v. 17, p. 406-409.

Wright, C.W., 1915, Geology and ore deposits of Copper Mountain and Kasaan Peninsula, Alaska: U.S. Geological Survey Professional Paper 87, 110 p.

Wright, F.E., and Wright, C.W., 1908, The Ketchikan and Wrangell mining districts, Alaska: U.S. Geological Survey Bulletin 347, 210 p.
Zaw, K., Gemmell, J.B., Large, R.R., Mernagh, T.P., and Ryan, C.G., 1996, Evolution and source of ore fluids in the stringer system, Hellyer VHMS deposit, Tasmania, Australia; evidence from fluid inclusion microthermometry and geochemistry: Ore Geology Reviews, v. 10, no. 3-6, p. 251-278.

Zumsteg, C.L., Karl, S.M., Haeussler, P.J., and Himmelberg, G.R., 2004, Recognition of three metamorphic events within the Wales Group on Prince of Wales and Dall Islands, southeastern Alaska [abs.]: Geological Society of America Abstracts with Programs, v. 36, no. 5, p. 135. 